Division of Geological \& Geophysical Surveys

PRELIMINARY INTERPRETIVE REPORT 2005-7

\title{
PRELIMINARY SUMMARY OF THE 2005 FIELD SEASON: PORT MOLLER, HERENDEEN BAY, AND DILLINGHAM AREAS, BRISTOL BAY BASIN, ALASKA PENINSULA
}

by

Paul L. Decker ${ }^{1}$, Emily S. Finzel ${ }^{2}$, Kenneth D. Ridgway ${ }^{3}$, Rocky R. Reifenstuhl ${ }^{2}$, and Robert B. Blodgett ${ }^{4}$

\footnotetext{
${ }^{1}$ Alaska Division of Oil \& Gas, Anchorage

${ }^{2}$ Alaska Division of Geological \& Geophysical Surveys, Fairbanks

${ }^{3}$ Purdue University

${ }^{4}$ Consulting Paleontologist, Anchorage
}

October 2005

THIS REPORT HAS NOT BEEN REVIEWED FOR

TECHNICAL CONTENT (EXCEPT AS NOTED IN TEXT) OR FOR CONFORMITY TO THE EDITORIAL STANDARDS OF DGGS.

\author{
Released by \\ STATE OF ALASKA \\ DEPARTMENT OF NATURAL RESOURCES \\ Division of Geological \& Geophysical Surveys \\ 3354 College Rd. \\ Fairbanks, Alaska 99709-3707
}




\section{Table of Contents}

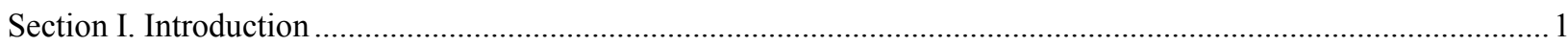

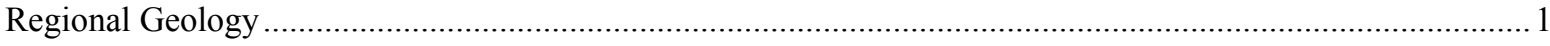

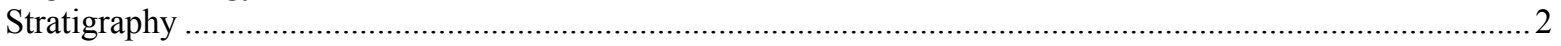

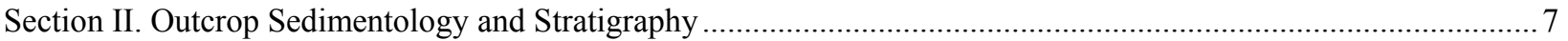

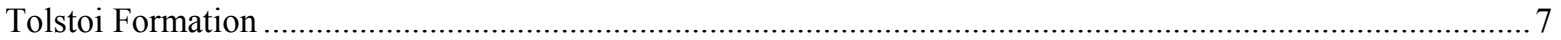

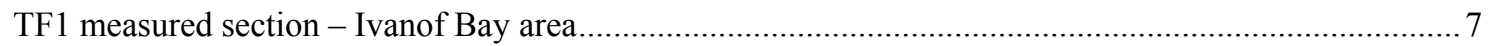

Stepovak Formation.....................................................................................................................

SV1 measured section - Chichagof Bay area …………................................................................ 7

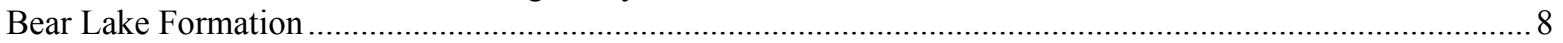

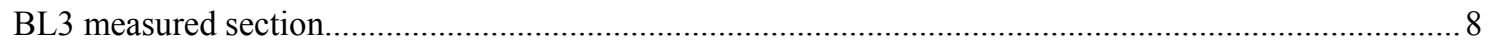

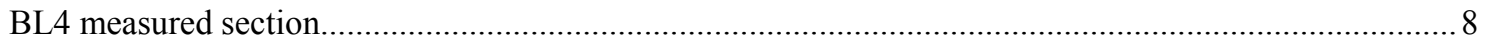

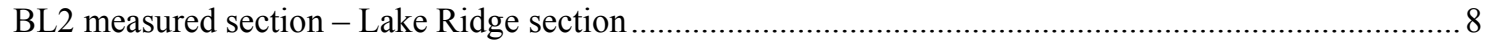

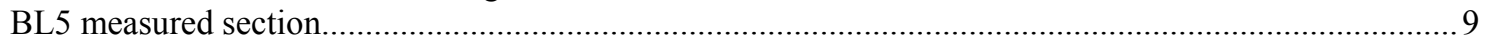

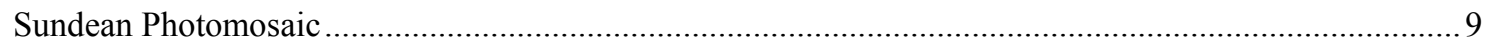

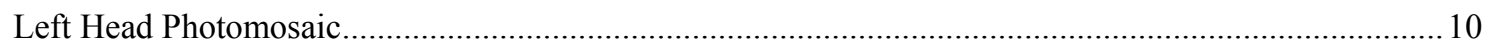

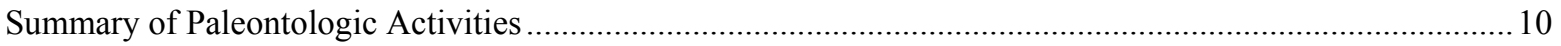

Section III. Outcrop Distribution of the Miocene-Pliocene Unconformity and Character of

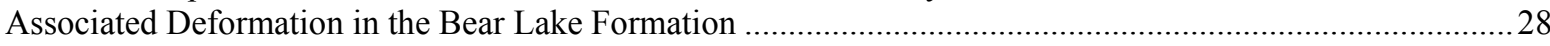

Section IV. Outcrop Structure of the Naknek and Bear Lake Formations, Black Hills and

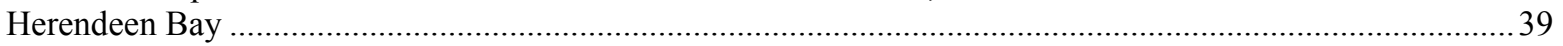

Fracture Orientations in the Jurassic Naknek Formation....................................................................................39

Folding and Faulting of the Bear Lake Formation, Coal Point Area, Herendeen Bay ....................................... 39

Section V. Outcrop Organic Geochemistry and Coal Evaluation........................................................................ 43

Section VI. Isotope Geochemistry, Composition, and Origin of Natural Gas Seep in Herendeen

Formation Hot Springs, Port Moller Area ……….................................................................................. 49

Section VII. Investigation of Historically Reported Oil Seeps in the Greater Dillingham Area ................................51

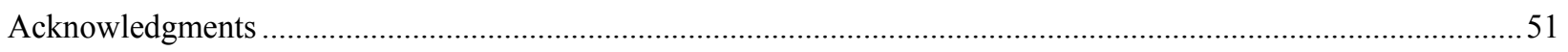

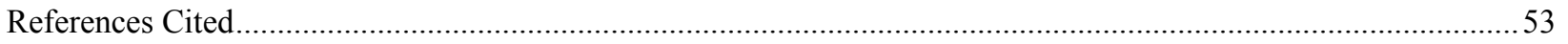




\title{
Preliminary Summary of the 2005 Field Season: Port Moller, Herendeen Bay, and Dillingham Areas, Bristol Bay Basin, Alaska Peninsula
}

\author{
Section I. Introduction \\ by E.S. Finzel
}

The Alaska Division of Geological \& Geophysical Surveys (DGGS), in collaboration with the Alaska Division of Oil \& Gas (DOG), Purdue University, and the University of Alaska Fairbanks, is engaged in an ongoing study of the oil and gas potential of the Bristol Bay basin. To aid the evaluation of the subsurface geology of Mesozoic and Tertiary units in this basin, surface geological studies were conducted along the coast and mountains of the Alaska Peninsula during the 2005 field season. Investigations consisted of three phases. The first phase, in the Greater Dillingham area, was devoted to geochemical sampling at localities previously reported as possible oil seeps. The second phase involved sampling of Mesozoic source rock units on the Pacific coast at Puale Bay. Based near Port Moller at Bear Lake, the third phase was the most extensive, focusing on a variety of objectives both in that vicinity and at more remote localities between the Sandy River to the east, the Black Hills to the west, and Ivanof, Chichagof, and Pavlof Bays on the Pacific coast. Investigations in that region included: (1) interpretive sedimentology and measurement of stratigraphic sections in the Paleocene to Eocene Tolstoi and Oligocene Stepovak formations, (2) a continuing study of the depositional environment of the Miocene Bear Lake and the Pliocene Milky River formations, (3) documentation of the Miocene-Pliocene angular unconformity and interpretation of associated deformation, (4) structural reconnaissance in Mesozoic and Tertiary units in the Black Hills and Herendeen Bay areas, (5) sampling and measurement of coals from Upper Cretaceous, Paleogene, and Neogene units to determine thickness, rank, hydrocarbon content, and source potential, (6) collection of a diverse sample suite from all units for analysis of porosity, permeability, petrography, micro- and megafossil biostratigraphy, source rock quality, and thermal maturity, and (7) sampling of natural gas from the Herendeen Hot Springs gas seep for carbon and deuterium isotope analysis to definitively determine whether it is of biogenic or thermogenic origin, as well as to verify its composition as determined from a 2004 sample. This report contains preliminary field observations, interpretation, and available analytical results; subsequent reports will present additional analytical results and interpretations.

DGGS issued an internally reviewed document summarizing the 2004 field season, including preliminary interpretation of analytical results (Reifenstuhl and others, 2005). A more extensive paper, combining subsurface well and seismic interpretations and more results from the 2004 field season, was issued as an internally reviewed report (Finzel and others, 2005a). Other reports and abstracts related to these field studies that address Bristol Bay geology include Reifenstuhl and others (2005), Reifenstuhl and Finzel (2005), Finzel and others (2005b), Blodgett (in prep.), and White (in prep.). Additional geologic data and interpretation have been prepared and released to the public by DOG as CDROMs and as web publications (http://www.dog.dnr.state.ak.us/oil/products/publications/akpeninsula/ak peninsula.htm).

Under contract to DOG, Micropaleo Consultants generated and interpreted micropaleontologic data from ten onshore wells in the Alaska Peninsula 2005 areawide lease sale boundary and the offshore North Aleutian COST 1 well from the Bristol Bay basin, defining a consistent and publicly available biostratigraphic zonation for the basin. Their report (Mickey and others, 2005) is now available for download at the DOG website above, and includes text, tables, photomicrographs, biostratigraphic summaries, and correlation cross sections with petrophysical well logs. In addition, DOG has published a three-volume CD-ROM data compilation (DOG; 2004; DOG, 2005) and map series (Meyer and others, 2004a, b, c, and d) summarizing geological information and digital well data, scanned well logs, mapped gravity and aeromagnetic data, and publicly available seismic data, converted to workstation-ready SEG-Y format, all retrievable at the same web address.

\section{Regional Geology}

The Bristol Bay basin (also known as the North Aleutian basin) is a northeast-trending, sediment-filled structural depression that lies beneath the northwestern lowlands of the Alaska Peninsula and the Bering Sea shelf (fig. 1.1). The basin developed in a back-arc setting after the accretion of the Alaska Peninsula terrane at the end of the Mesozoic (Jones and Silberling, 1979; Wilson and others, 1985; Marlow and others, 1994). Its Cenozoic subsidence history comprises three major phases: (1) Paleocene to Eocene extensional and strike-slip faulting, (2) late Eocene to middle Miocene flexural subsidence, and (3) late Miocene to Holocene asymmetric subsidence driven by depositional loading of its southeastern margin as sediments and volcanics were shed from the Alaska Peninsula (Walker and others, 2003; Worrall, 1991; Finzel and others, 2005a). The basin is asymmetric, with a gently thinning northwest flank and Cenozoic deposits exceeding 6,000 m thick near the onshore southeastern margin (Kirschner, 
1988; Walker and others, 2003; Finzel and others, 2005a). The Alaska Peninsula is built mainly from the accreted rocks of the Alaska Peninsula terrane, itself composed of two contrasting subterranes defined by Wilson and others (1985) as the Iliamna and Chignik subterranes. These subterranes are separated on the northeast end of the peninsula by the Bruin Bay Fault. The Iliamna subterrane, consisting of highly deformed, locally intruded, and regionally metamorphosed Paleozoic and Mesozoic rocks, including the Alaska-Aleutian Range batholith, lies northwest of the Bruin Bay Fault (fig. 1.1) and forms the northeast margin of the Bristol Bay basin. The Chignik subterrane constitutes unmetamorphosed Permian to Upper Cretaceous sedimentary rocks, including Upper Triassic and Middle Jurassic oil-prone source rocks. These Chignik subterrane strata are present southeast of the Bruin Bay Fault, and are also exposed along much of the southern and southwestern Alaska Peninsula, in contrast to the Iliamna subterrane, which is not proven to exist farther southwest than the Becharof Lake area. West of Port Moller, the Bristol Bay basin is bordered to the south by Chignik subterrane sedimentary units in the Black Hills Uplift (fig. 1.1). The poorly exposed and probably complex belt of faulting and folding between the basin and the exposed Mesozoic strata is the informally named David River Zone. Given the lack of conclusive data, it remains unclear whether and how far Mesozoic source rocks of the Chignik subterrane extend beneath the reservoir-prone Cenozoic fill of the Bristol Bay basin. Geophysical data suggest the northern boundary of the basin, which lies beneath the Bering Sea shelf, may be formed by Mesozoic sedimentary, igneous, and metamorphic rocks (Marlow and others, 1994).

\section{Stratigraphic Overview}

A comprehensive summary of the stratigraphic succession on the Alaska Peninsula can be found in Detterman and others (1996). The following brief overview is drawn largely from their description and interpretations. The reader is referred to this reference and previous work cited therein for additional detail.

Mesozoic units (fig. 1.2) form the backbone of the Alaska Peninsula and are exposed mostly on the peninsula's southeast side (fig.1.1). The Upper Triassic Kamishak Formation is composed of about $800 \mathrm{~m}$ of limestone and lesser volcanic rocks. The Lower Jurassic Talkeetna Formation consists of about $400 \mathrm{~m}$ of tuffaceous sandstone and tuff. The overlying Middle Jurassic Kialagvik Formation is composed of a few hundred meters of sandstone, shale, and conglomerate. The Middle Jurassic Shelikof Formation is an approximately 1,400-m-thick fine-grained volcaniclastic unit deposited in deep to shallow water. The most widespread Mesozoic formation on the peninsula is the Upper Jurassic Naknek Formation, which has an average thickness of approximately 1,700 to 2,000 m. In this region, Detterman and others (1996) subdivided the Naknek Formation into five members: The Chisik Conglomerate Member, the Northeast Creek Sandstone Member, the Snug Harbor Siltstone Member, the Indecision Creek Sandstone Member, and the Katolinat Conglomerate Member. Though not described as such by Detterman and others (1996), the overall textural succession of the Naknek Formation suggests a major transgressive-regressive cycle. Lower Cretaceous units consist of the marine sandstones, siltstones, and shales of the Staniukovich Formation (Lower Neocomian), overlain by highly fossiliferous, calcareous sandstones of the Herendeen Formation (Upper Neocomian). Following an unconformity spanning approximately 40 m.y. of mid-Cretaceous time, sedimentation resumed in the Upper Cretaceous with the shallow marine, tidal flat, and nonmarine sandstones, siltstones, and coals of the Upper Cretaceous Chignik Formation (Fairchild, 1977; Detterman, 1978), and their deep-water equivalents, the turbidite sandstones, siltstones, and shales of the Upper Cretaceous Hoodoo Formation (Mancini and others, 1978; Molenaar, 1980; Detterman and others, 1996).

The Tertiary stratigraphic succession on the Alaska Peninsula (fig. 1.2) consists of mainly sedimentary rocks with varying amounts of volcaniclastic and primary volcanic input, deposited in a range of marine and nonmarine environments (Detterman and others, 1996). The Tolstoi and Bear Lake formations are exceptions, composed primarily of nonvolcanic sediments. The oldest Tertiary deposit is the Paleocene to Eocene Tolstoi Formation, which onlaps and is derived from the underlying Mesozoic sedimentary and plutonic rocks. At its type section along the eastern shore of Pavlof Bay (fig. 1.3), the Tolstoi Formation is at least $659 \mathrm{~m}$ thick, and represents a more marine environment than either the Tolstoi exposures farther northeast (Detterman and others, 1996) or the equivalent interval penetrated in the North Aleutian COST 1 well (Turner, 1988, Plate 1) to the north in Bristol Bay (fig. 1.3). The Stepovak Formation consists of about 2,000 m of late Eocene to Oligocene volcaniclastic siltstones and sandstones that intertongue extensively with primary volcanics of the Eocene to earliest Miocene Meshik magmatic arc along the southwest side of the peninsula. Exposures of the late Oligocene to earliest middle Miocene Unga Formation are limited to the Unga Island area on the Pacific side of the peninsula (fig. 1.3), and are dominated by subaerial deposits. Nonmarine to shallow marine deposits of the middle to late Miocene Bear Lake and Pliocene Milky River formations form spectacular exposures along the coast and mountains of the central Alaska Peninsula. Detterman and others (1996) estimate the thickness of the Bear Lake Formation at no more than approximately 1,000 m thick, consistent with our own subsurface interpretations of the North Aleutian COST 1 and Sandy River 1 wells (Finzel and others, 2005a and b; fig. 1.3). On the basis of current field and subsurface investigations, including reservoir quality 
studies by Helmold and Brizzolara (2005), we rank the Bear Lake Formation as perhaps the most prospective hydrocarbon reservoir objective in the region. The Milky River Formation is $465 \mathrm{~m}$ thick at its type section (Detterman and others, 1996) and thickens northward to approximately $775 \mathrm{~m}$ (our interpretation) in the Sandy River 1 well, where Detterman and others (1996) identified a subsurface reference section. Both in outcrop and in the subsurface, the Milky River is a complex mix of primary volcanic and only slightly reworked volcaniclastic rock types (Detterman and others, 1996; Helmold and Brizzolara, 2005). 


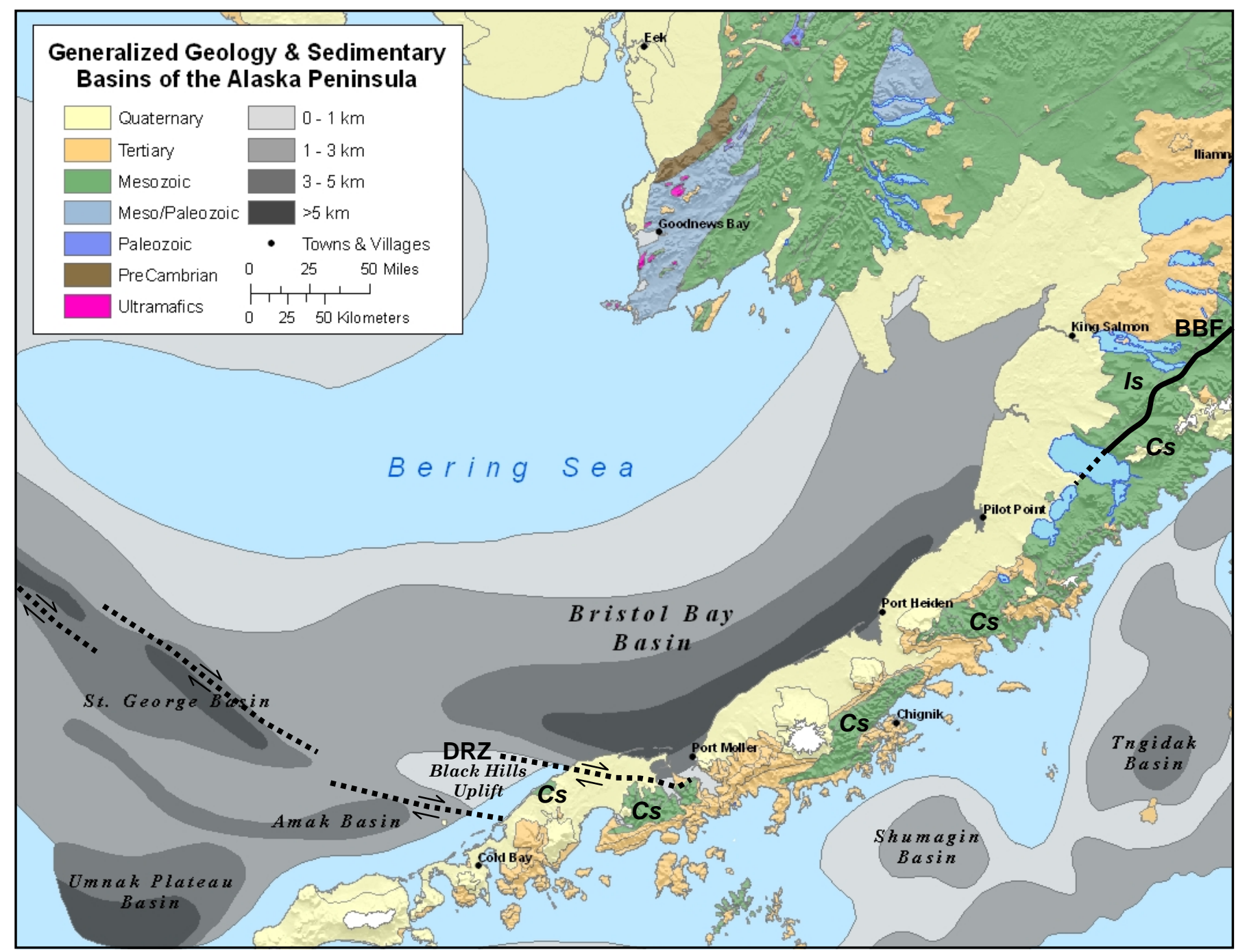

Figure 1.1. Location map showing the regional geology and tectonic elements of the Alaska Peninsula. Age-coded rock units are simplified from Beikman (1980), generalized isopachs of surrounding basins after Kirschner (1988); note asymmetry of the Bristol Bay back-arc basin. The Bruin Bay Fault (BBF) separates unmetamorphosed, oil-prone Mesozoic sedimentary rocks to the southeast (Chignik subterrane, Cs) from highly metamorphosed and intruded Mesozoic rocks to the northwest (Iliamna subterrane, Is), but the fault is not mappable southwest of the southern shore of Becharof Lake (e.g., Wilson and others, 1999). The informally named David River Zone (DRZ) west of Port Moller is a zone of combined dextral strike-slip and uplift that separates the subsiding Bristol Bay basin on the north from the transpressional Black Hills Uplift to the south, with exposures of upper Chignik subterrane strata at its crest. Schematic strike-slip faults in Bering Sea after Worrall (1991). 


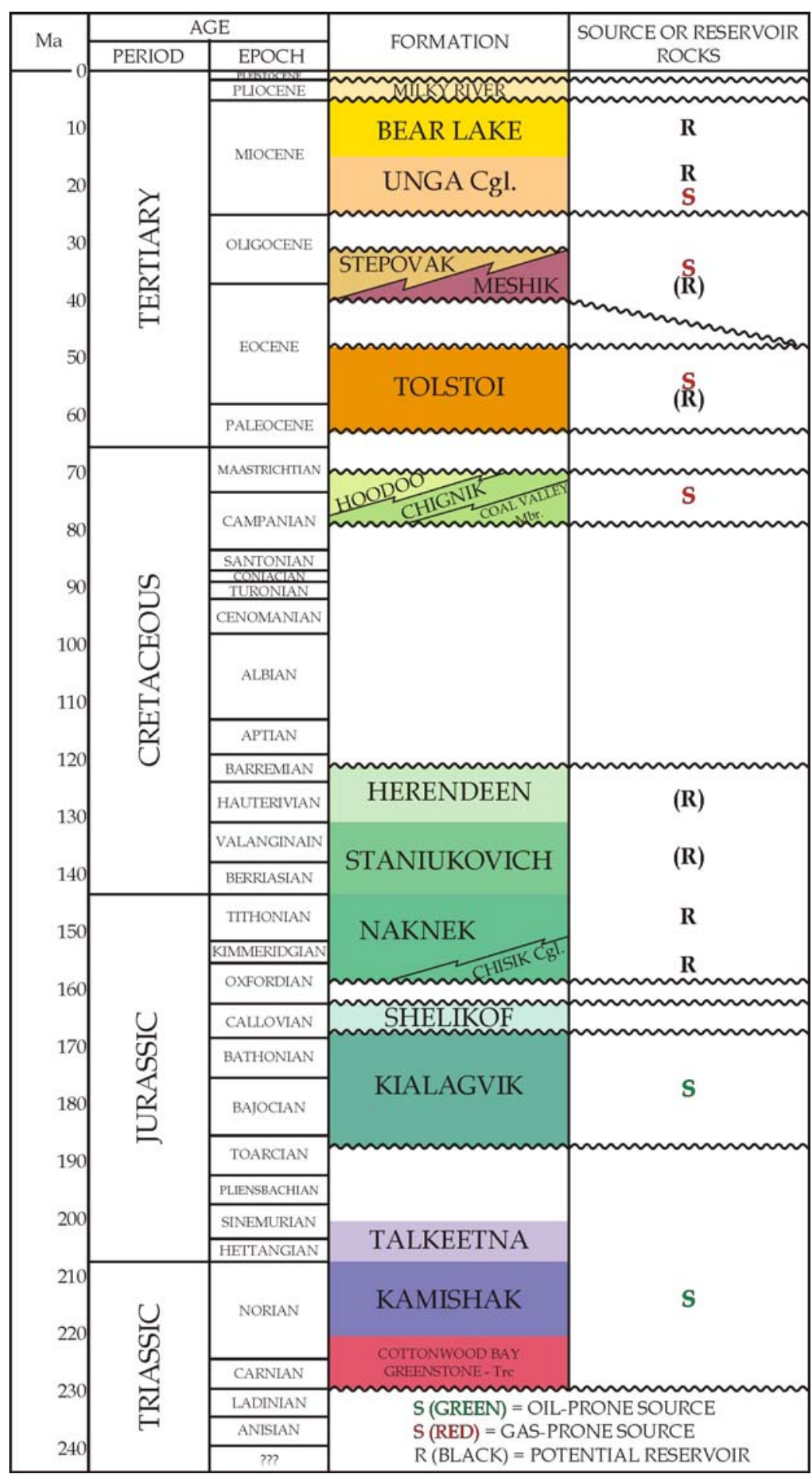

Figure 1.2 Composite stratigraphic column of the Bristol Bay Basin and Alaska Peninsula areas (from Hite, 2004). 


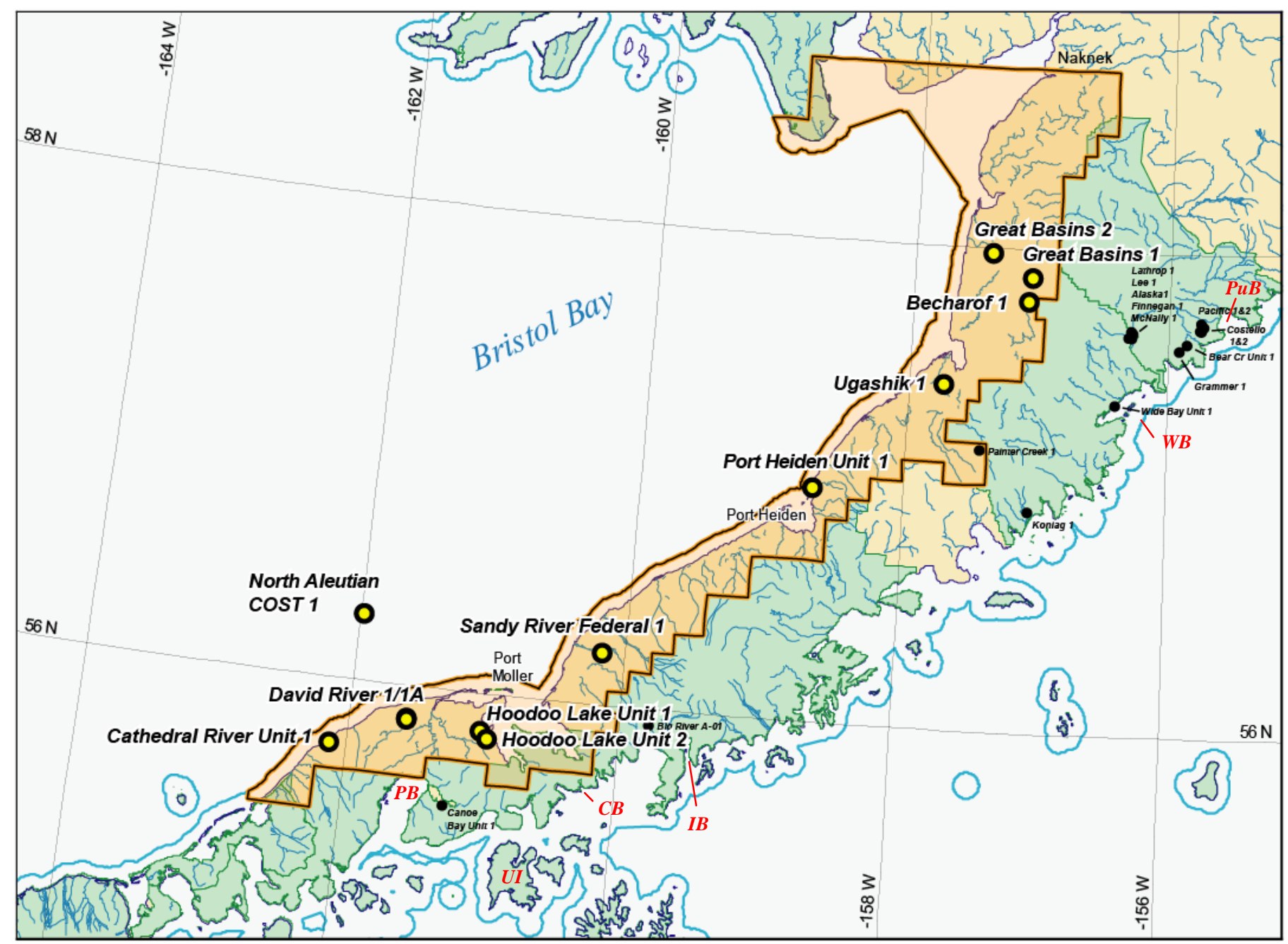

Figure 1.3. Map showing Alaska Peninsula areawide lease sale boundary (orange outline) and well locations. Larger symbols with yellow fill are wells included in publicly available biostratigraphic report (Mickey and others, 2005). Locality abbreviations in red font: Pavlof Bay (PB), Unga Island (UI), Chichagof Bay (CB), Ivanof Bay (IB), Wide Bay (WB), Puale Bay $(\mathrm{PuB})$ 


\section{Section II. Outcrop Sedimentology and Stratigraphy}

by K.D. Ridgway, E.S. Finzel, and R.B. Blodgett

Studies during the 2005 field season included documenting the stratigraphy and sedimentology of three Tertiary clastic units in six new measured sections (fig. 2.1). Formations represented are the Paleocene to Eocene Tolstoi Formation (section TF1), the Oligocene Stepovak Formation (section SV1), and the Miocene Bear Lake Formation (sections BL3, BL4, BL2, and BL5). The principal lithofacies and depositional interpretations of these measured sections are summarized in stratigraphic sequence below.

TF1 measured section - Ivanof Bay area

\section{Tolstoi Formation}

\section{Location:}

This section is located on the east side of Ivanof Bay at GPS location 55.88205\%159.46201․ The section location is labeled TF1 on figure 2.1 and is located on the Stepovak Bay D-5 Quadrangle. This section is representative of the upper part of the Tolstoi Formation.

\section{Lithofacies Description:}

This section is characterized by thick bedded, trough cross-stratified sandstone interbedded with carbonaceous shale and coal. The sandstone beds average $~ 10 \mathrm{~m}$ in thickness, but locally range up to $40 \mathrm{~m}$ thick (314 $\mathrm{m}$ on sheet 1; fig. 2.2). Sandstone beds have tabular geometries at the scale of the outcrop. Stratification in the sandstone is commonly draped by carbonaceous lamina (fig. 2.3). Fine-grained intervals in the section are up to $20 \mathrm{~m}$ thick, and contain coalified lenses and abundant well preserved leaf fossils (fig. 2.4).

\section{Depositional Interpretation:}

The lithofacies in this measured section are interpreted as fluvial-dominated deltaic deposits. The dominance of trough cross-stratification in the thick sandstones and the non-erosive tabular geometries of the sandstone beds are indicative of well organized fluvial systems. Thick sections of carbonaceous shale and coals are characteristic of associated extensive overbank environments. The thick finer-grained interval with coal lenses implies that fluvial channels were stable for long periods of time to allow for peat development. These observations and inferences, coupled with our tentative interpretation of sandstones above our measured section as delta-front deposits, and the previous interpretation of the lower part of the Tolstoi Formation as marine strata (Detterman and others, 1996), suggest to us that the Tolstoi Formation in the Ivanof Bay area is part of a large progradational deltaic package.

\section{$\underline{\text { SV1 measured section - Chichagof Bay area }}$}

\section{Stepovak Formation}

\section{Location:}

This section is located on the east side of Chichagof Bay at GPS location $55.66864^{\circ} / 160.20856^{\circ}$. The section location is labeled SV1 on figure 2.1 and is located in the Port Moller C-1 Quadrangle. This section is representative of the middle part of the Stepovak Formation.

\section{Lithofacies Description}

The Stepovak Formation in our 98 m measured section consists of a repetitive succession of very coarsegrained sandstone interbedded with thick recessive packages of gray siltstone (figs. 2.5 and 2.6). The sandstones are poorly sorted, distinctively lacking in sedimentary structures, and form tabular beds averaging $\sim 6 \mathrm{~m}$ thick (fig. 2.6). The sandstones contain very little internal bedding; most are massive. They are dominated by angular volcanic lithic fragments and locally contain large, outsized volcanic clasts of mainly white tuff (fig. 2.7). The siltstone-dominated lithofacies is massive, contains no sedimentary structures, and has very rare marine fossils (two mollusk fossils were found during a day of field work). Volcanic flows are present throughout the section; the thickest flow is recorded between 16 and $26 \mathrm{~m}$ in the measured section of figure 2.5 .

\section{Depositional Interpretation:}

We tentatively interpret the Stepovak Formation at our measured section locality as medial submarine fan deposits based on the poor sorting, angular grains, tabular geometries, scarcity of fossils, and large outsized volcanic clasts. All these features are diagnostic of rapid emplacement of sediment from a nearby volcanic source. The lack of tractive sedimentary structures and internal bedding in the sandstones are consistent with mass flow depositional 
processes. We interpret all the strata in this section to have been deposited by gravitational forces associated with sediment gravity flows on submarine fan systems adjacent to an active volcanic arc.

\section{BL3 measured section}

\section{Bear Lake Formation}

\section{Location:}

This measured section is located in the headwaters of the Milky River (BL3 on fig 2.1 and sheet 2). The GPS location for the base of the section is 55.97592 $/ 160.00093^{\circ}$, in the Port Moller D-1 Quadrangle. Bedding has a strike and dip of $242^{\circ} / 32^{\circ} \mathrm{NW}$. This section is representative of the lower part of the Bear Lake Formation.

\section{Lithofacies Description:}

Section BL3 (sheet 2) consists of a lower package of bioturbated sandstone and shale exposed in the lower 142 meters of the section. Fine-grained sandstone throughout this package is highly bioturbated (fig. 2.8). The most abundant trace fossil is Arenicolites, best exposed in a bed from 53.5 to $85 \mathrm{~m}$ (fig. 2.9). Marine megafossils are rare in this section but some mollusk fragments were found. The upper part of the section (142-272 m) is dominated by medium-grained sandstone characterized by abundant mud rip-ups and plant fragments. There are no discrete marine fossil horizons in this part of the section but a few disarticulated mollusk fragments (fewer than five specimens) and one sand dollar (echinoid) were observed.

\section{Depositional Interpretation:}

The lower part of this section is interpreted as transitional intertidal and subtidal deposits based on the extensive bioturbation and limited presence of marine fossils. The trace fossil Arenicolites is indicative of intertidal environments. The thick sections of continuously bioturbated sandstone are most consistent with subtidal deposition. The relative lack of marine megafossils suggests an environmental stress such as the brackish water conditions of the intertidal zone.

\section{BL4 measured section}

Location:

This measured section is located in the headwaters of the Milky River (BL4 on fig. 2.1 and sheet 2) The GPS location for the base of the section is 55.98997\% $160.00034^{\circ}$, in the Port Moller D-1 Quadrangle. Bedding has a strike and dip of $235^{\circ} / 45^{\circ} \mathrm{NW}$. This section is representative of the middle part of Bear Lake Formation.

\section{Lithofacies Description:}

This $354 \mathrm{~m}$ section is dominated by three main lithofacies: Wavy-bedded sandstone and shale, flaser-bedded sandstone and shale, and coal (fig. 2.10). The coal beds are a minor component but are distinctive markers in the middle part of the Bear Lake Formation. The coals are interbedded with carbonaceous shale; the thickest individual bed measured was $2.5 \mathrm{~m}$. The bulk of this measured section consists of wavy- and flaser-bedded sandstone and shale. These lithologies contain no bioturbation or marine megafossils. Plant impressions are abundant throughout the measured section.

\section{Depositional Interpretation:}

The flaser- and wavy-bedded sandstone that makes up most of this section requires an environment characterized by abrupt changes in flow velocity. These types of sedimentary structures are most common in intertidal environments. The lack of both bioturbation and marine macrofossils suggest most of these strata were deposited in the upper, freshwater-influenced part of the regional estuarine system. The coal, carbonaceous shales, and common plant fragments suggest at least a short-lived regression to nonmarine conditions, with the development of a mirerich coastal plain during mid-Bear Lake time.

\section{BL2 - Lake Ridge measured section}

\section{Location:}

This measured section is located south of Bear Lake on a ridge that forms the eastern side of Bear Lake (BL2 on fig. 2.1 and sheet 2). The GPS location for the base of the section is $55.95292^{\circ} / 160.09412^{\circ}$, in the Port Moller D-1 Quadrangle. Bedding has a strike and dip of $51^{\circ} / 20^{\circ} \mathrm{NW}$ at this locality. This section is representative of the upper part of Bear Lake Formation.

\section{Lithofacies Description:}


Section BL2 (sheet 2) consists of two main lithofacies associations: A lower unit of ripple-laminated and flaser-bedded sandstone, and an upper unit of massive and ripple-laminated sandstone. The lower unit extends from 0 to $68 \mathrm{~m}$ and includes interbedded conglomerate from about 31 to $68 \mathrm{~m}$, and locally contains boulder size clasts up to $41 \mathrm{~cm}$ in diameter. Most of the clasts in the conglomerate are quartz, chert, and volcanic lithologies; however, one conglomerate bed contains only volcanic clasts $(64-68 \mathrm{~m})$. The lower unit also contains one fossil bed characterized by disarticulated mussel shells $(59 \mathrm{~m})$. Paleocurrent data from planar cross stratified sandstone $(30 \mathrm{~m})$ indicate northwestward sediment transport for this part of the section.

The upper part of the section extends from 68 to $216 \mathrm{~m}$. This unit is characterized by ripple-laminated and massive sandstone, both of which are bioturbated. Skolithos assemblage trace fossils are most common, and include robust Ophiomorpha burrows (fig. 2.11). This part of the section contains one sandstone bed that is rich in marine megafossils and is described in more detail later in this section.

\section{Depositional Interpretation:}

We interpret the lower ripple-laminated and flaser-bedded sandstone unit to represent deposition in sandrich tidal flat environments. The character and abundance of the small-scale bedforms are the primary evidence for this interpretation, particularly the flaser bedding, which suggests deposition under fluctuating hydraulic conditions. The distinct lack of bioturbation, the minor marine macrofossils, and the periodic presence of boulder-size detritus suggest that these strata were deposited in the proximal part of a regional estuarine system near a point source for coarse detritus. Brackish water chemistries in the proximal parts of estuarine systems limit the presence of invertebrate organisms and related burrowers. The upper part of this measured section is interpreted as more marine-dominated sand-rich tidal flat deposits relative to the lower part of the section. The presence of bioturbation, flaser bedding, and more open marine fauna (discussed below) are all consistent with this interpretation.

\section{BL5 measured section}

Location:

This measured section is located in the headwaters of the Milky River (BL5 on fig. 2.1 and sheet 2). The GPS location for the base of the section is $55.99745^{\circ} / 160.01964^{\circ}$, in the Port Moller D-1 Quadrangle. Bedding has a strike and dip of $228^{\circ} / 29^{\circ} \mathrm{NW}$ at this locality. This section is representative of the upper part of Bear Lake Formation.

\section{Lithofacies Description}

This $112 \mathrm{~m}$ section consists of two main facies associations: A lower package of sandstone and conglomerate with well developed lateral accretion bedding and flaser/wavy bedding, overlain by an upper package of fossilrich bioturbated sandstone. The contact between the two packages is very gradational. The lower package commonly contains $\sim 10$-m-thick sequences going from trough cross-stratified conglomerate at the base, to flaser-bedded sandstone overlain by wavy-bedded sandstone and shale (fig. 2.12). Within these sequences, the lateral accretion beds often have coarse-grained foresets that grade downdip into ripple-laminated shale (fig. 2.13). There is minor bioturbation in the lower package and occasional disarticulated mollusk fossils along discrete horizons. Plant fragments are the most common fossil in this part of the section. The upper part of the section is characterized by tabular beds of highly bioturbated sandstone rich in marine fossils. Clams and gastropods are common in this part of the section (fig. 2.14).

\section{Depositional Interpretation:}

We interpret the lower package to represent deposition in sand-rich tidal flat environments. The common association of lateral accretion surfaces, and flaser- and wavy-bedded sandstone are the primary evidence for this interpretation. The distinct lack of bioturbation and the limited marine macrofossils are also consistent with this interpretation. The upper package is interpreted as subtidal marine sandstone based on the extensive bioturbation, tabular bed geometries, and the diverse marine invertebrate fossil assemblages.

\section{Sundean Photo Mosaic}

This section is located along the peninsula between the Right Head and Left Head at the head of Port Moller Bay (fig. 2.1). The GPS location for the base of the section is $55.81693^{\circ} / 160.31337^{\circ}$, in the Port Moller D-1 Quadrangle. Bedding has a strike and dip of $70^{\circ} / 13^{\circ} \mathrm{NW}$. A detailed measured stratigraphic section and depositional interpretation for this outcrop are presented in Finzel and others (2005a).

Figure 2.9 is a photo mosaic of the Bear Lake Formation at the Sundean locality. This annotated outcrop image illustrates lateral bedding continuity and lithofacies heterogeneity at the scale of a hydrocarbon reservoir. The 
Sundean outcrop can be divided into three depositional packages (A, B, and C). The lower package is heterogeneous and consists of many thin beds of intertidal sandstone and siltstone (A on fig. 2.15). These lithofacies are heavily bioturbated and include Arenicolites, probable Diplocraterion or related shafts of the Skolithos ichnofacies assemblage, and Planolites traces, the latter being the most common (fig. 2.16). This lower package also contains flaserbedded sandstone interbedded with conglomerate (fig. 2.17); individual conglomerate beds fine upward (fig. 2.18). Marine macrofossils were not found in this part of the outcrop.

The middle part of the outcrop (B on fig. 2.15) is characterized by well sorted sandstone with lateral accretion bedding (1 on fig. 2.15). Internally these sandstones have well developed planar cross stratification (fig. 2.19). Individual sandstone beds are 1- $4 \mathrm{~m}$ thick. The middle package also contains a thick bed of mussel fossils (2 on fig. 2.15 and fig. 2.20). The sandstone in this middle package is well sorted, but individual beds are laterally discontinuous on the scale of tens of meters and are separated by thin beds of rippled-laminated siltstone (3 on fig. 2.15). These finer-grained units and the well indurated mussel bed would probably act as vertical permeability barriers, limiting the overall reservoir quality.

The upper part of the outcrop ( $\mathrm{C}$ on fig. 2.15) consists of subtidal sandstone characterized by flaser and wavy bedding. This facies also contains lenses of conglomerate that are discontinuous on a scale of a few meters. The upper package is also characterized by ripple-laminated siltstone (4 on fig. 2.15) that is mainly lenticular- and wavybedded. The best reservoir quality facies is present in this upper package where the most continuous thick, sand-rich sections are preserved. Both horizontal and vertical permeability should be high in this upper package.

\section{Left Head Photo Mosaic}

This section is located along the east coast of Port Moller Bay southeast of Egg Island and is labeled LH1 on figure 2.1. The GPS location for the base of the section is $55.87441^{\circ} / 160.34538^{\circ}$, in the Port Moller D-2 Quadrangle. A detailed measured stratigraphic section and depositional interpretation for this outcrop are presented in Finzel and others (2005a).

Figure 2.15 is a photo mosaic of the Bear Lake Formation at the Left Head locality. The Left Head section can be divided into three depositional packages (A, B, and C) that might impact reservoir compartmentalization. The lower package consists of thick-bedded sandstones interpreted as fluvial-dominated deposits of a regional estuarine system (A on fig. 2.21). Much of this lower package is stratigraphically below the part of the section shown on figure 2.21. The major characteristics of this lower package are well stratified medium- to coarse-grained sandstone with abundant coalified plant fragments, a distinct lack of bioturbation or marine macrofossils, and an absence of mud drapes on foresets (fig. 2.22). These sandstone beds are laterally continuous at the outcrop scale (fig. 2.21), but display some internal lenticularity at a scale of tens of meters. The tabular sandstone geometry and lack of interbedded finer-grained facies should result in excellent vertical and horizontal permeabilities in this package.

The middle package consists of interbedded finer-grained facies characterized by flaser, wavy, and lenticular bedding (B on fig. 2.21). These facies are interbedded with well sorted sandstone exhibiting lateral accretion bedding and trough cross stratification with common thin mudstone draped on the foresets (fig. 2.22). Marine macrofossils in this part of the section are in discrete beds and consist mainly of mussel fossils. The fossils are usually disarticulated and concentrated with clasts of conglomerate along specific horizons (fig. 2.23). These layers of coarse clasts and fossils are interpreted as storm layers.

The upper part of the section consists of thick, bioturbated sandstone that sometimes contains swaley stratification (C on fig. 2.21). The upper package contains the most diverse assemblage of trace fossils that we have documented in the Bear Lake Formation. Common trace fossils include Thalassinoides, crab burrows, and unidentified segmented, vertical shafts that are probably either insect or crustacean dwelling burrows (fig. 2.24). The extensive bioturbation has completely homogenized many of these tabular sandstones and may have produced fairly uniform horizontal and vertical permeabilities. Macrofossils in this upper package are found scattered throughout the sandstone but never in specific horizons.

\section{Summary of Paleontologic Activities}

The collection of megafossils (primarily mollusks) by R.B. Blodgett during the 2005 field season was focused primarily on the Bear Lake (Late Oligocene-Late Miocene) and Milky River (Pliocene) formations. These are intended to augment the ongoing sedimentology studies of these units by Finzel and others (2005a and b). The megafossils support the previous interpretation by Ridgway and Finzel that the Bear Lake Formation represents a transgressive succession from basal nonmarine to shallow shelfal conditions near the top of the unit. Plant collections were made from the nonmarine coal-bearing section exposed near the base of the type section of the Bear Lake Formation, but have not yet been analyzed. At the Sundean and Left Head sections (figs. 2.15 and 2.21), fossil collections were tied directly to measured sections and indicate a probable Middle Miocene age. At these localities, the 
Bear Lake Formation contains many monotaxic coquinoid beds of the distinctive mussel Mytilus (Plicatomytilus) gratacapi Allison and Addicott. This species is thought to range from Middle to Late Miocene in age, and to reflect shallow-water, lower intertidal to very shallow subtidal water depths. The biogeographic distribution of this bivalve appears to be limited to the southern part of the Alaska Peninsula. Elsewhere in western North America, another species, Mytilus (Plicatomytilus) middendorffi Grewingk appears to have ecologically replaced the former species (Allison and Addicott, 1976). Slight upward deepening is suggested in both the Sundean and Left Head sections by the modest faunal diversity increase in the uppermost shell beds, where in addition to the mussel $M$. (P.) gratacapi, additional faunal elements also appear, including the bivalve Clinocardium, the gastropod genus Crepidula, as well as naticid gastropods.

The upper shallow marine portion of the Bear Lake Formation was sampled at several localities on the southeast side of Bear Lake, near the location of section 17B of Burk (1965, p. 216). The fauna here is of Late Miocene age and is quite diverse, with several tens of mollusks species represented. Of special interest was the collection of some rare faunal elements such as a shark tooth (fig. 2.25), an unidentified vertebra, a desmostylid tooth, and a crab carapace (fig. 2.26) probably belonging to the species Metacarcinus goederti (Schweitzer and Feldmann, 2000). These unique fossil elements will be further analyzed by Louis Jacobs (vertebrate paleontologist, Southern Methodist University) and Rodney Feldmann (crab specialist, Kent State University).

Collections of mollusks were made from both the lowermost and upper parts of the overlying Milky River Formation. These specimens warrant thorough taxonomic study, as they call into question certain regional biostratigraphic correlations. Our observations suggest the marine mollusk assemblage that characterizes the Tachilni Formation may also be well represented in the upper part of the Pliocene Milky River Formation, suggesting these units are at least partially age-equivalent. Named by Waldron (1961) at the southwestern end of the Alaska Peninsula, the Tachilni was first dated by MacNeil and others (1961) as early Pliocene in age. Marincovich (1983) reinterpreted the Tachilni Formation as Late Miocene, and thus partially time-equivalent to the Bear Lake Formation. This change has been adopted by subsequent workers (Detterman and others, 1996), so a close inspection of similar assemblages of potentially different age from the Milky River Formation will be worthwhile. In addition, the Milky River mollusks collected from the southern part of Sandy Ridge (informal name, figs. 2.1, 3.1) shows those exposures to be entirely shallow-marine (shelfal) in origin, in contrast to exposures of the same unit farther north and on other ridges to the west, which consist in large part of more proximal volcaniclastic breccias and primary volcanic rocks.

There has been considerable historical variability in the age designations and the placement of formation boundaries within the Cenozoic system on the Alaska Peninsula. For example, much of the Milky River Formation, now known from diatom studies to be of Pliocene age (Gladenkov, 2003), was identified as Middle(?) to Late Miocene Bear Lake Formation on Sandy Ridge by Detterman and others (1981), Marincovich and Powell (1989), and Wilson and others (1999). Conversely, Burk (1965) assigned a Pliocene age to outcrops now mapped as Miocene Bear Lake Formation at Coal Point on the western shore of Herendeen Bay (section CP1 of Finzel and others, 2005a and b). Megafossils collected in this study will be subject to ongoing analyses aimed at resolving outstanding questions on the biostratigraphy, paleoecology, and sequence stratigraphic framework of the Miocene-Pliocene rocks on the southern part of the Alaska Peninsula. In addition to a molluscan-based biostratigraphy, future work will attempt to establish an additional, independent diatom-based zonation. Diatoms have provided the most detailed and refined zonation for the Miocene-Pliocene of the Alaska Peninsula (John Larson, personal commun., 2005; Gladenkov, 2003), rivaled secondarily by mollusks. The combination of the above two biostratigraphic analyses with ongoing palynological studies should greatly refine the zonation of Neogene stratigraphy on the Alaska Peninsula. 


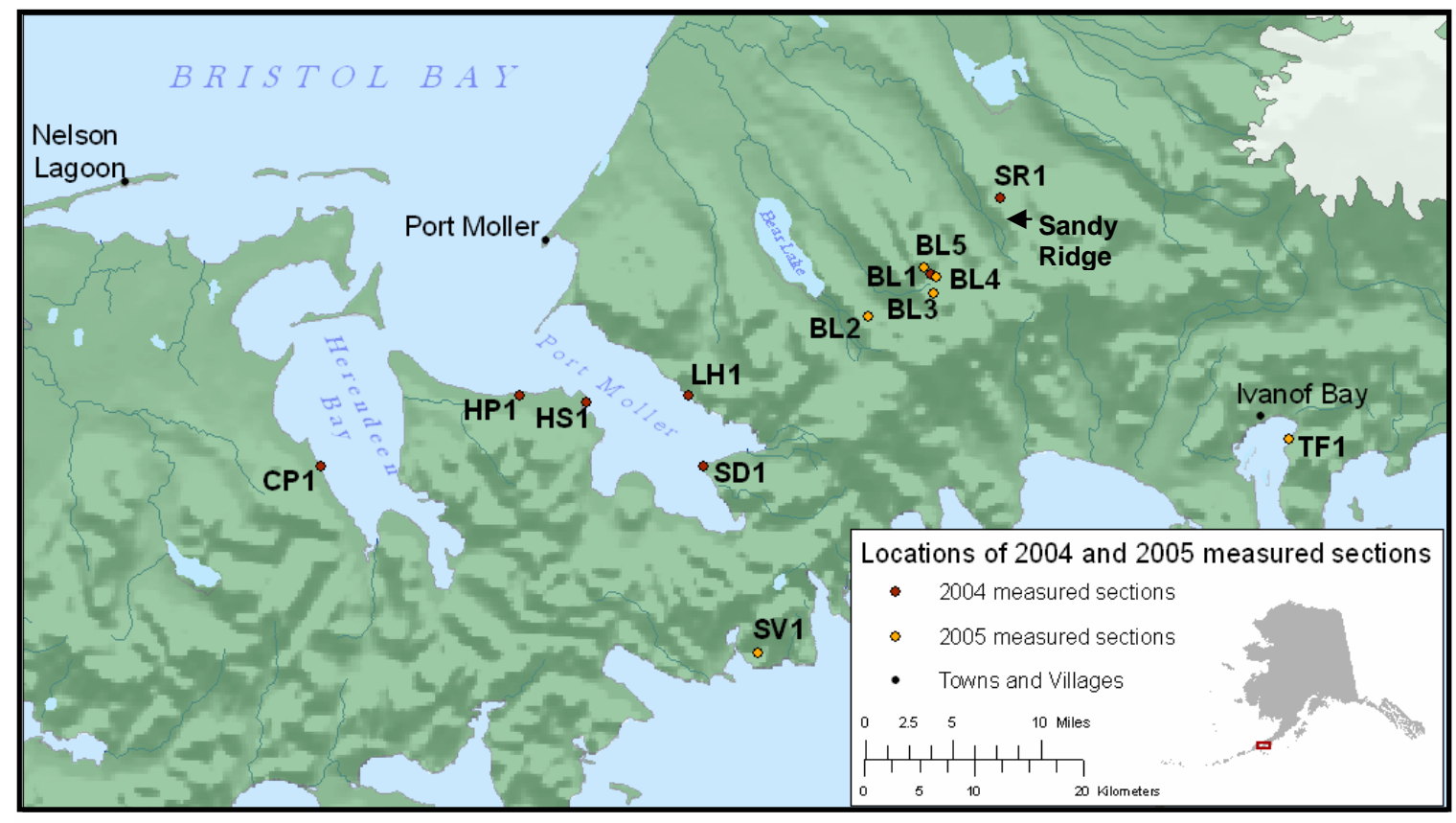

Figure 2.1. Digital elevation model of the Port Moller and Herendeen Bay areas, showing locations of measured sections and important geographic features.

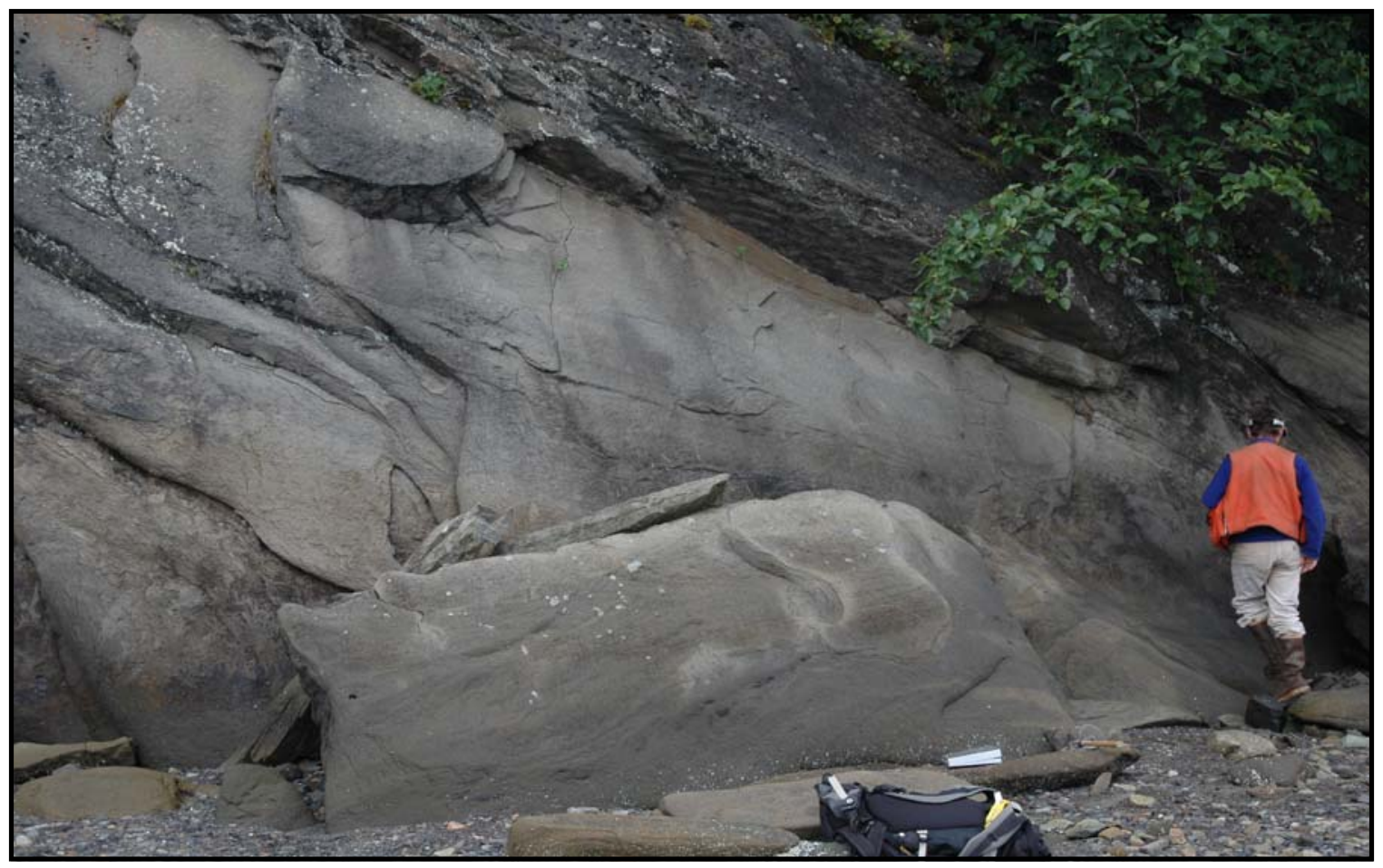

Figure 2.2. A thick, trough cross-stratified sandstone typical of the Tolstoi 1 section (view to the east). 


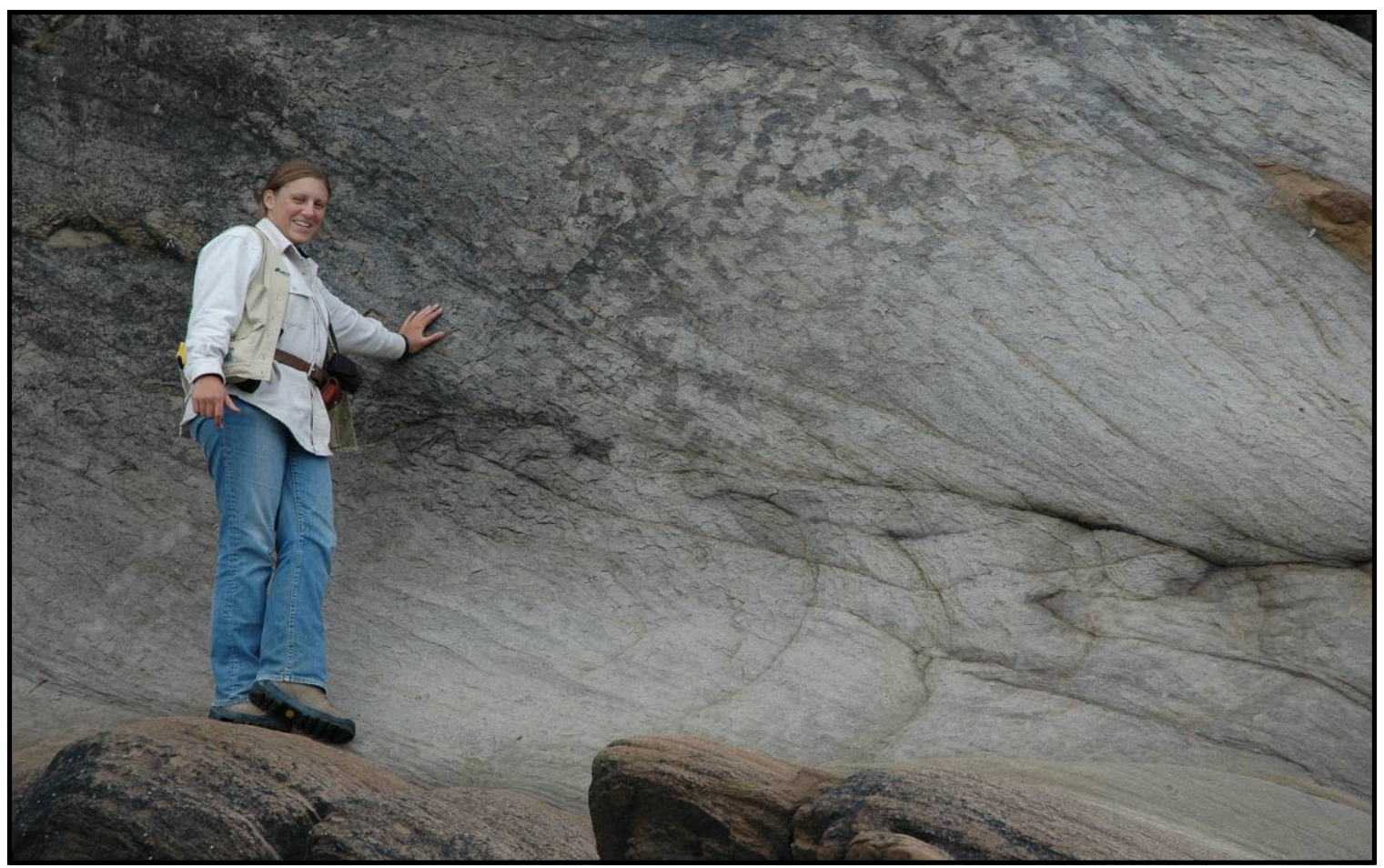

Figure 2.3. Large, trough cross-stratification with carbonaceous material on the foresets in the Tolstoi 1 section, Ivanof Bay (view to the east).

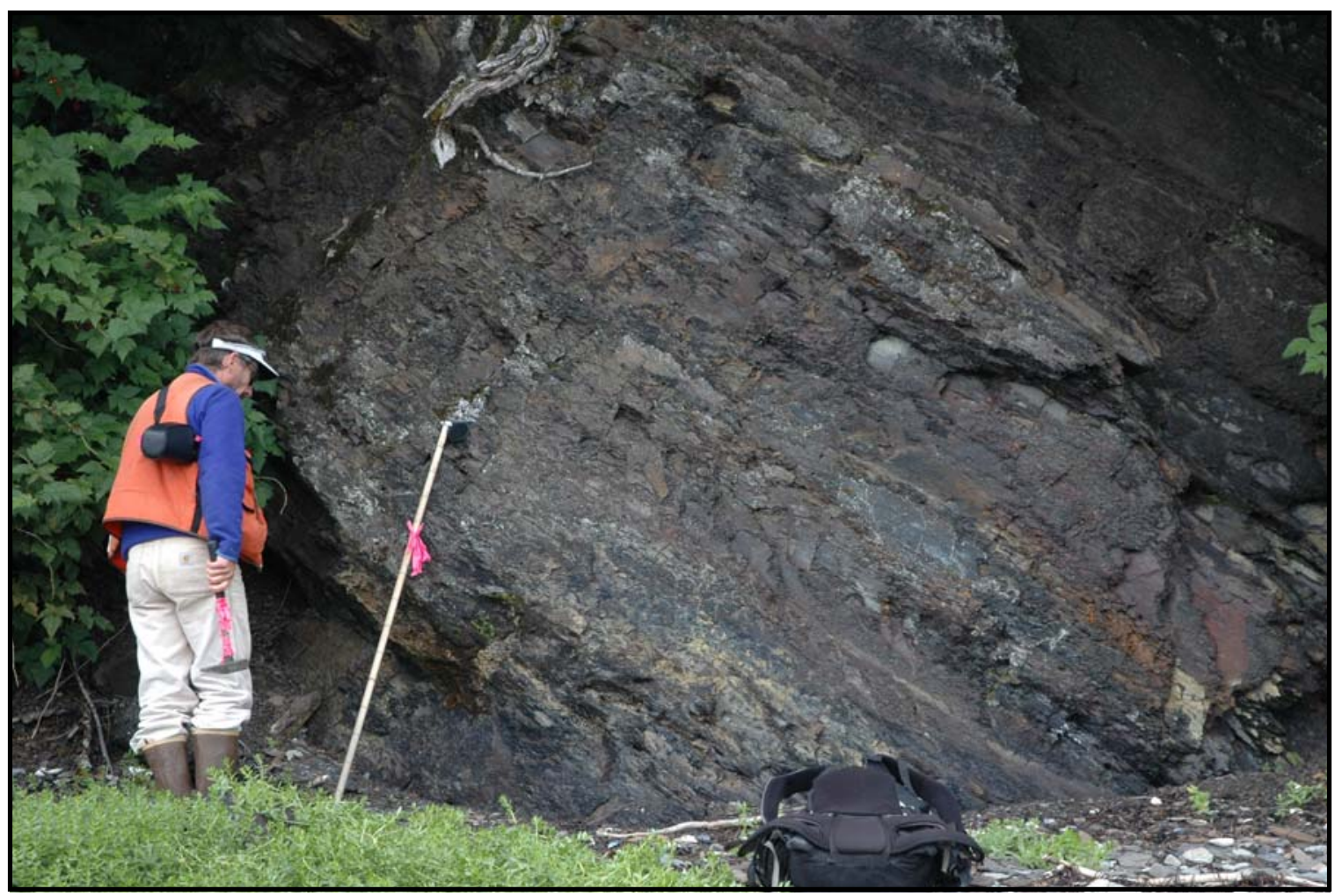

Figure 2.4. A thick, fine-grained interval in the Tolstoi 1 section, Ivanof Bay (view to the east). These intervals commonly contain coalified lenses and well preserved leaf fossils. 


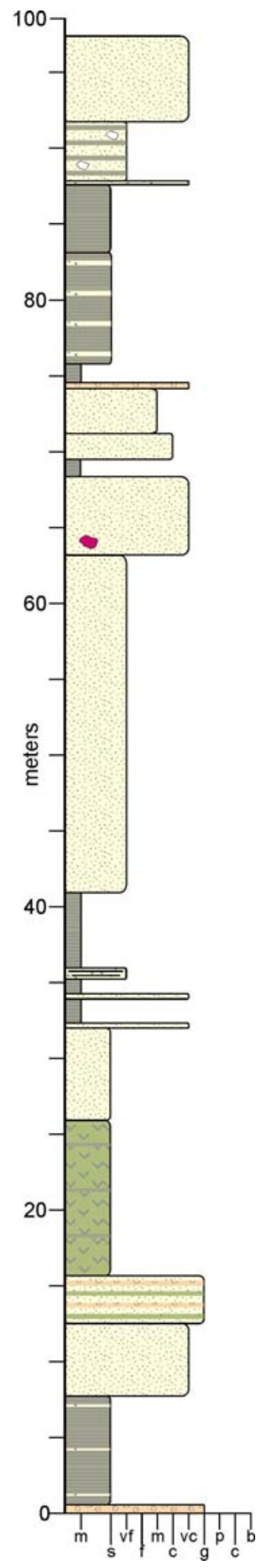

\begin{tabular}{|l|} 
Lithologies and Sedimentary Structures \\
Sudstone or siltstone \\
Condstone
\end{tabular}

Figure 2.5. Stepovak 1 measured section, Stepovak Formation, Chichagof Bay. See figure 2.1 for location. 


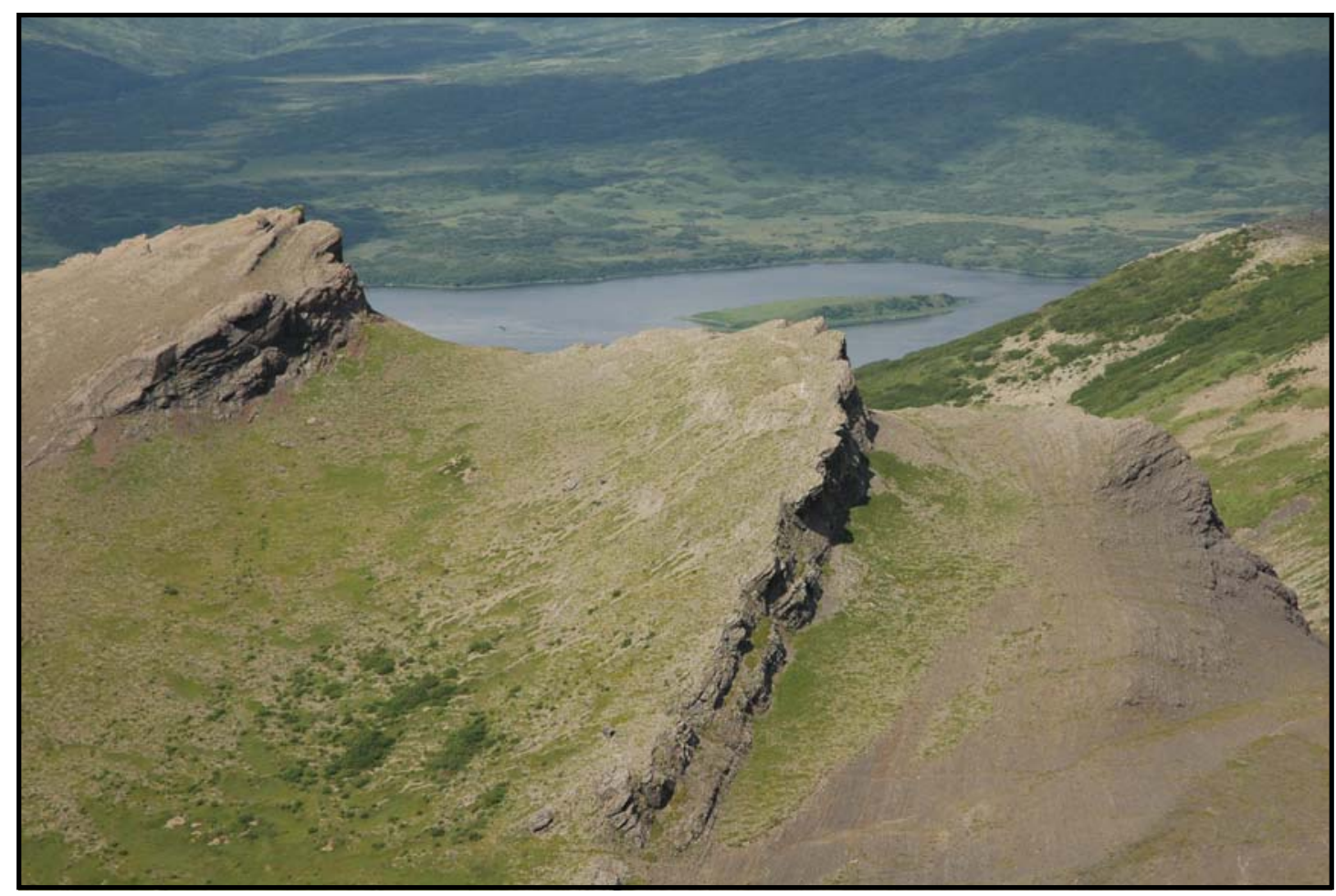

Figure 2.6. Aerial view (toward the west) of the Stepovak 1 measured section. This section consists mostly of very coarse-grained sandstone interbedded with thick packages of gray siltstone.

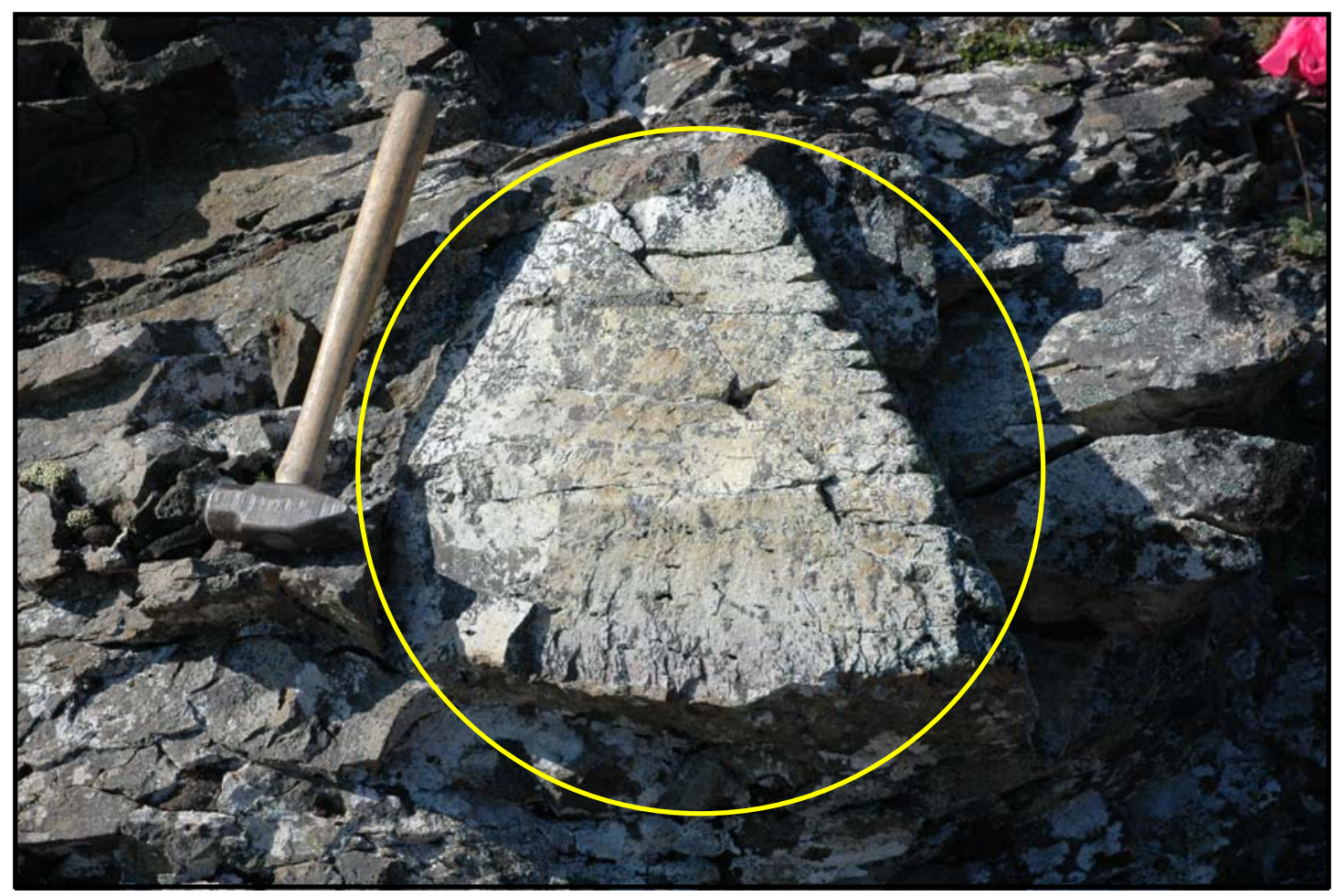

Figure 2.7. Large, outsized volcanic clasts (in yellow circle) of white tuff are common in the Stepovak 1 section. 


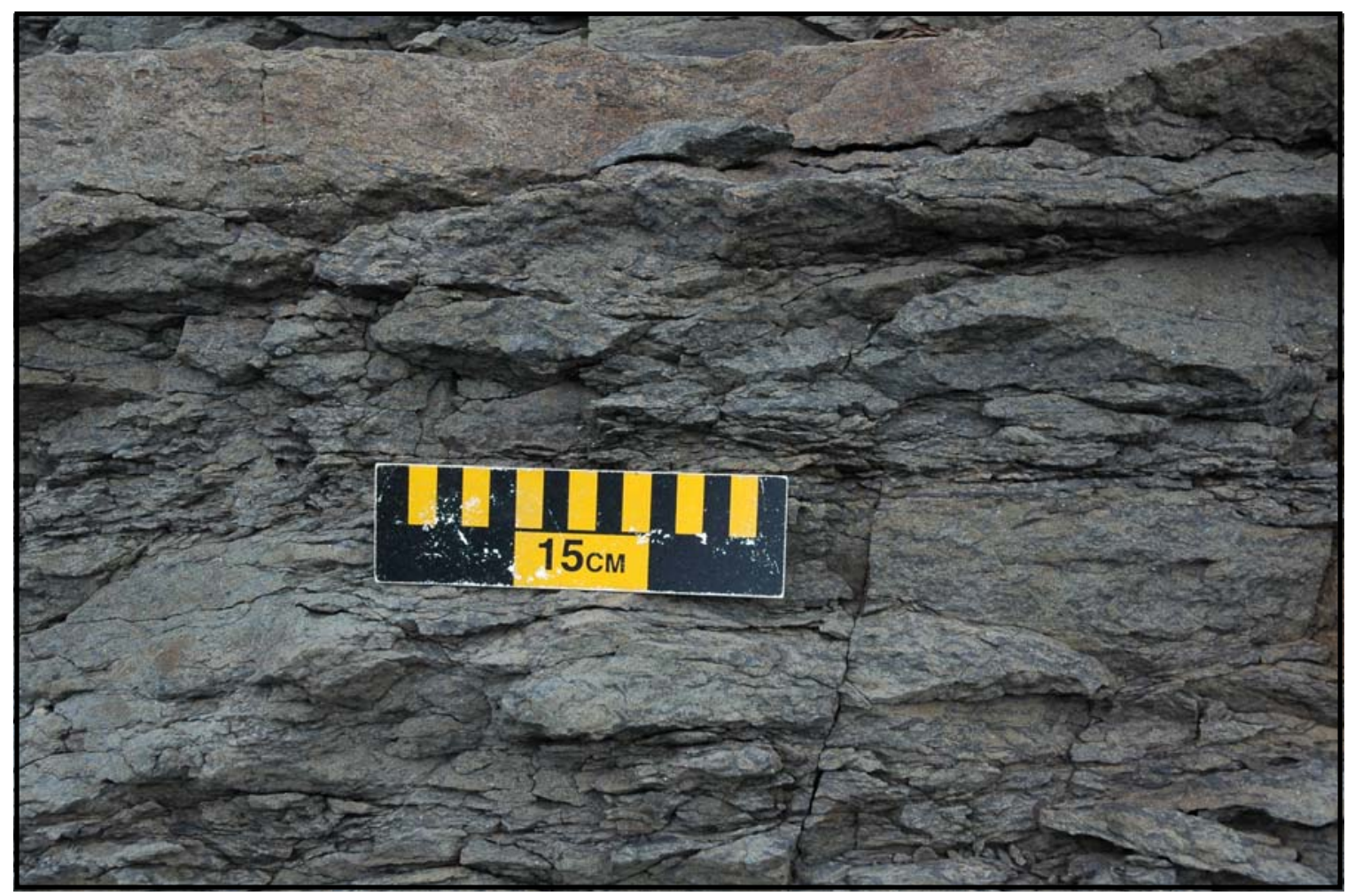

Figure 2.8. Mottled, highly bioturbated fine-grained sandstone typical of the Bear Lake 3 measured section.

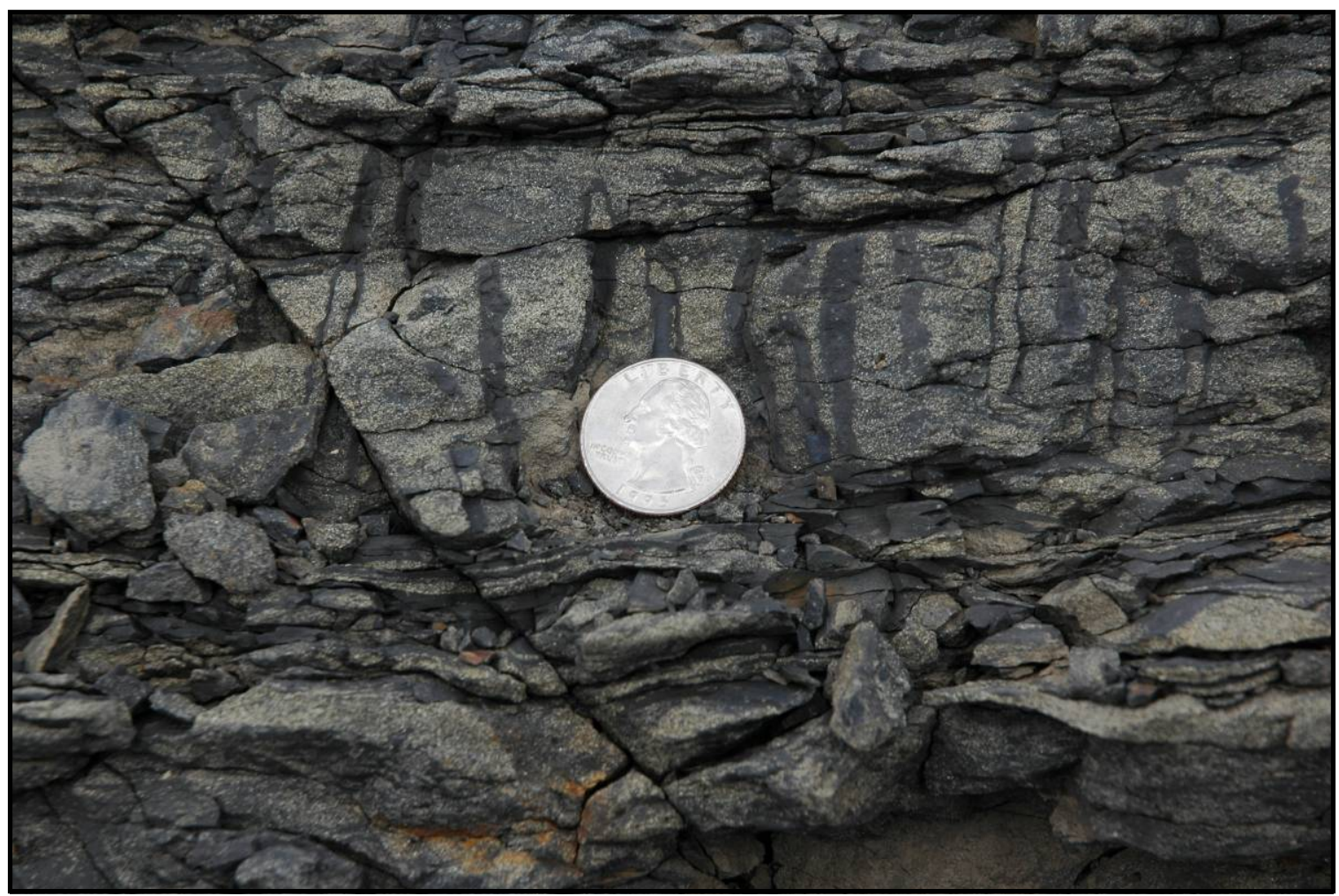

Figure 2.9. Arenicolites burrows are the most common trace fossil in the Bear Lake 3 measured section. 
Figure 2.10. View to the north of the Bear Lake 4 measured section. Light brown layers are sand-dominated intervals, gray layers are silt-dominated intervals, and black layers are carbonaceous shale and coal.
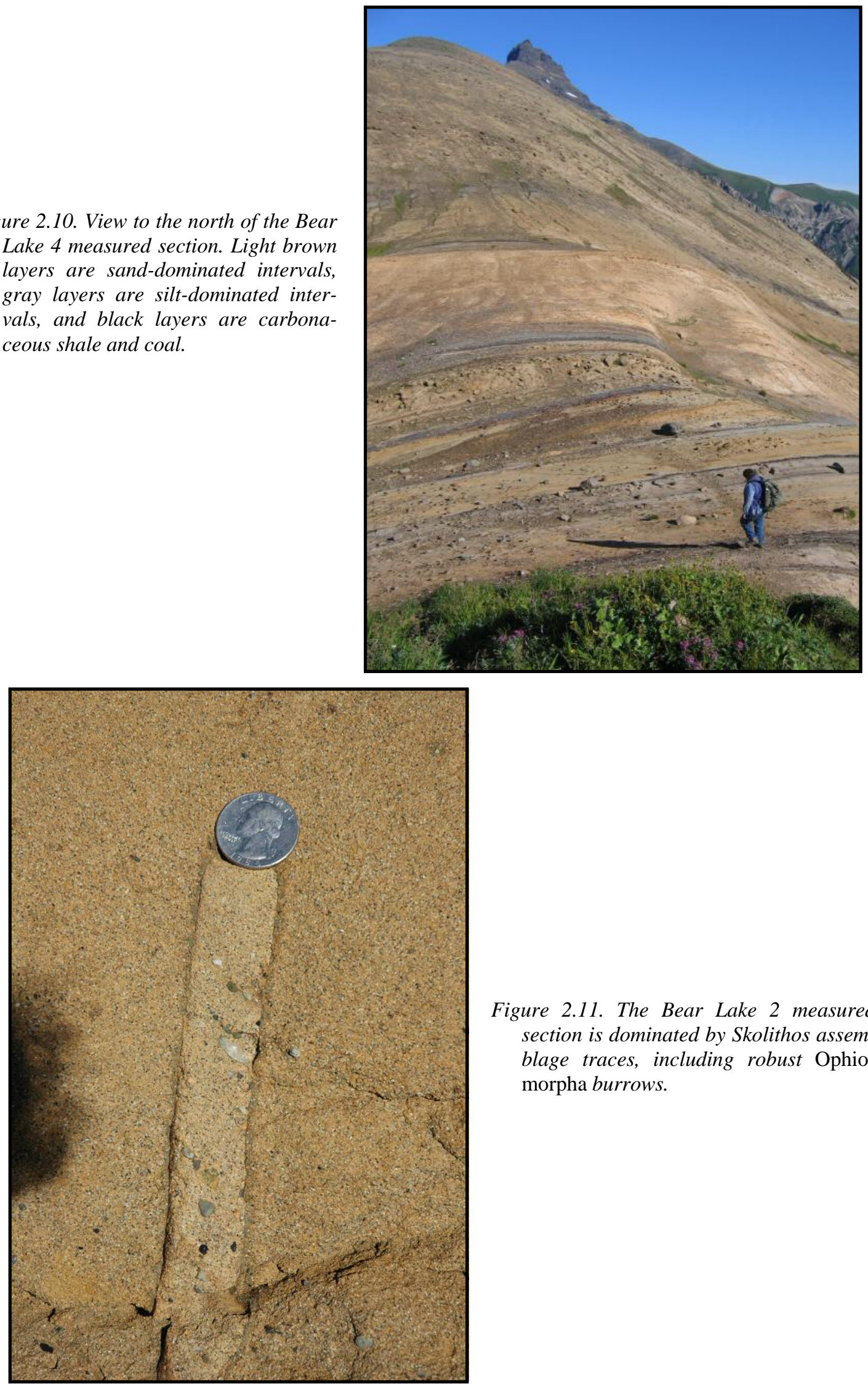

Figure 2.11. The Bear Lake 2 measured section is dominated by Skolithos assemblage traces, including robust Ophiomorpha burrows. 


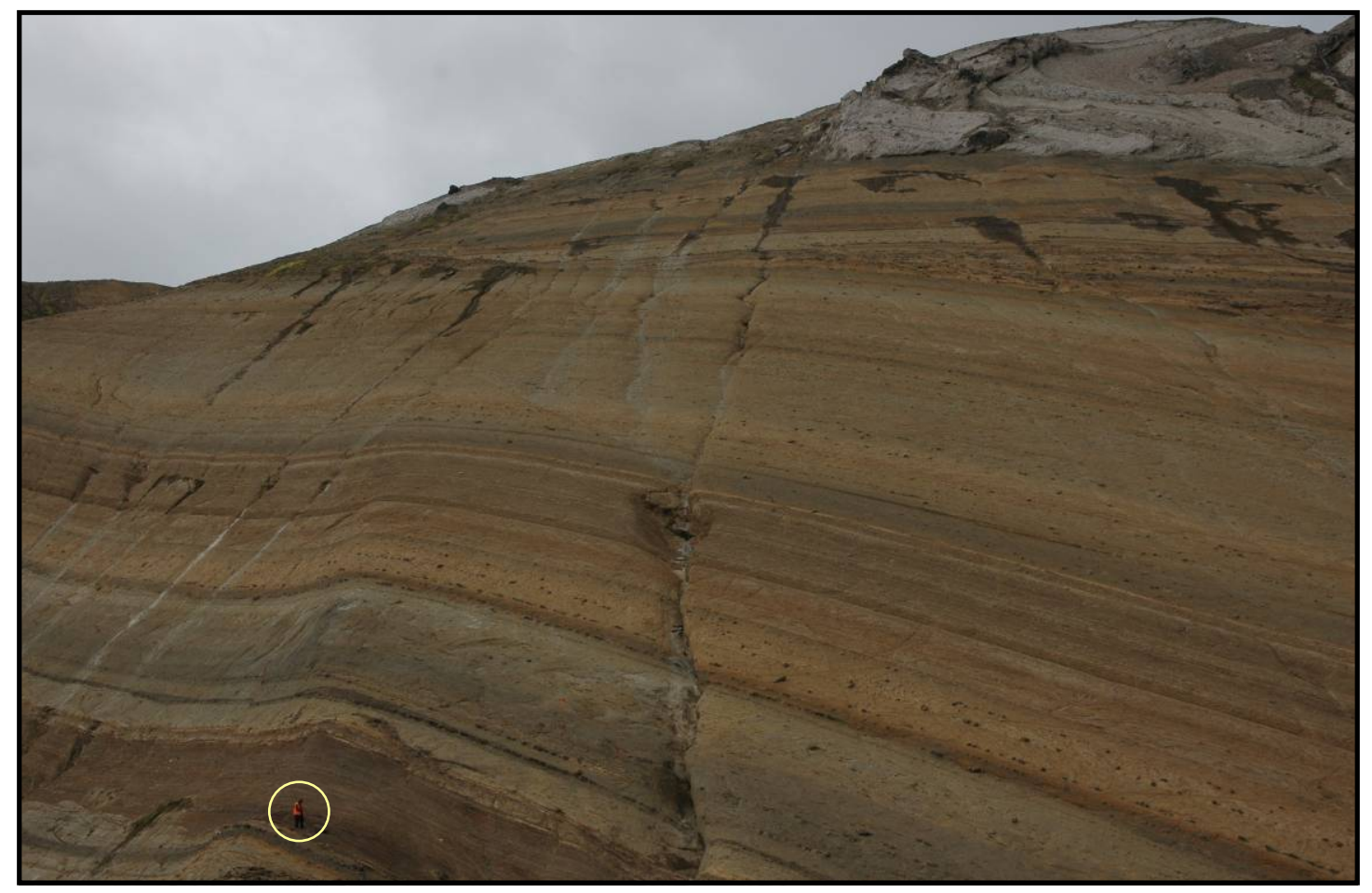

Figure 2.12. Photo of Bear Lake 5 measured section, showing typical successions of conglomerate overlain by flaser- and wavy-bedded sandstone, capped by a shale layer. Geologist (circled) for scale. See Section III of this report for discussion of structural disruptions evident at the top of this exposure.

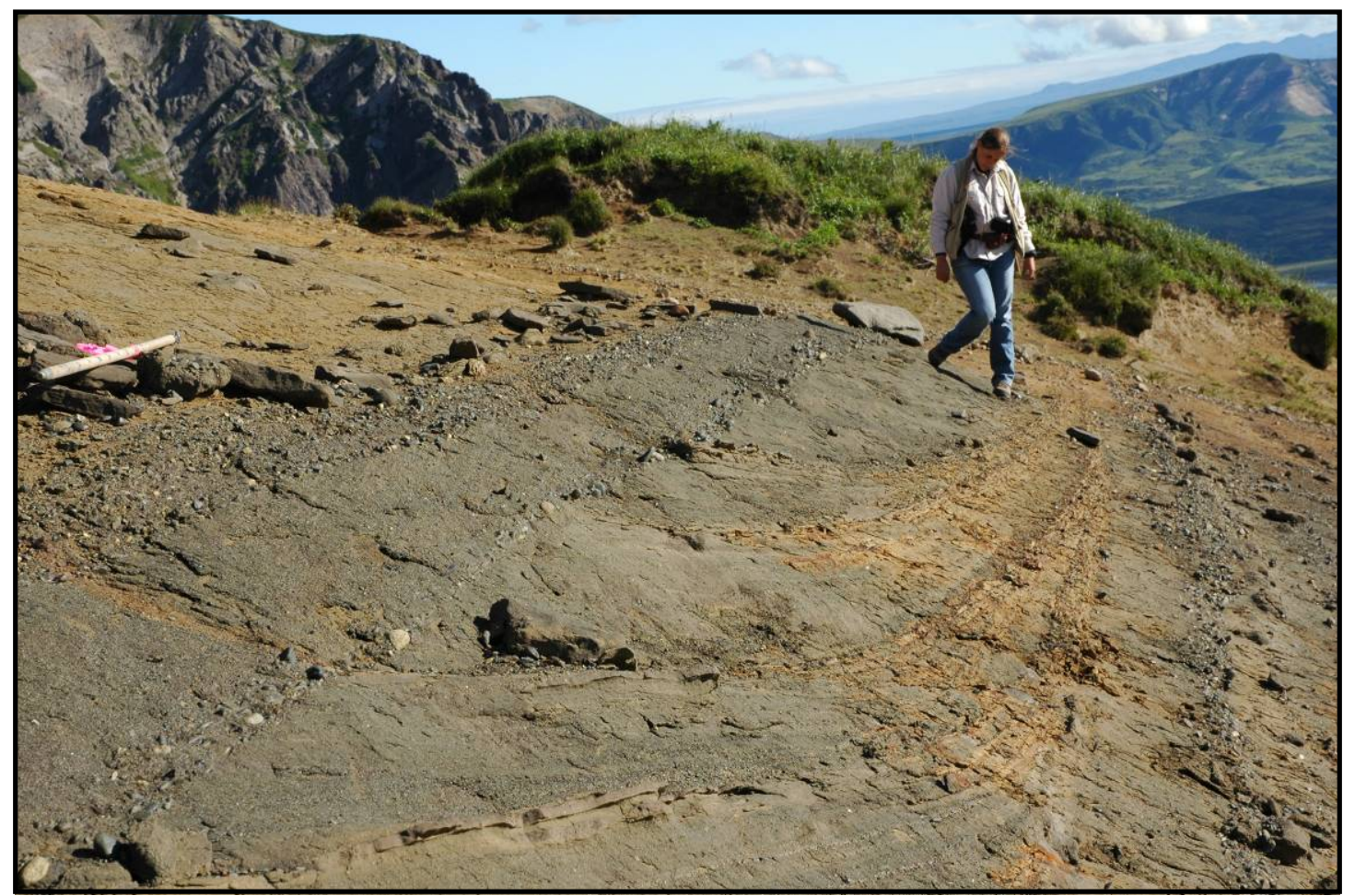

Figure 2.13. Lateral accretion surfaces with coarse-grained material on the foresets commonly grade downdip into ripple-laminated shale in the Bear Lake 5 measured section. 


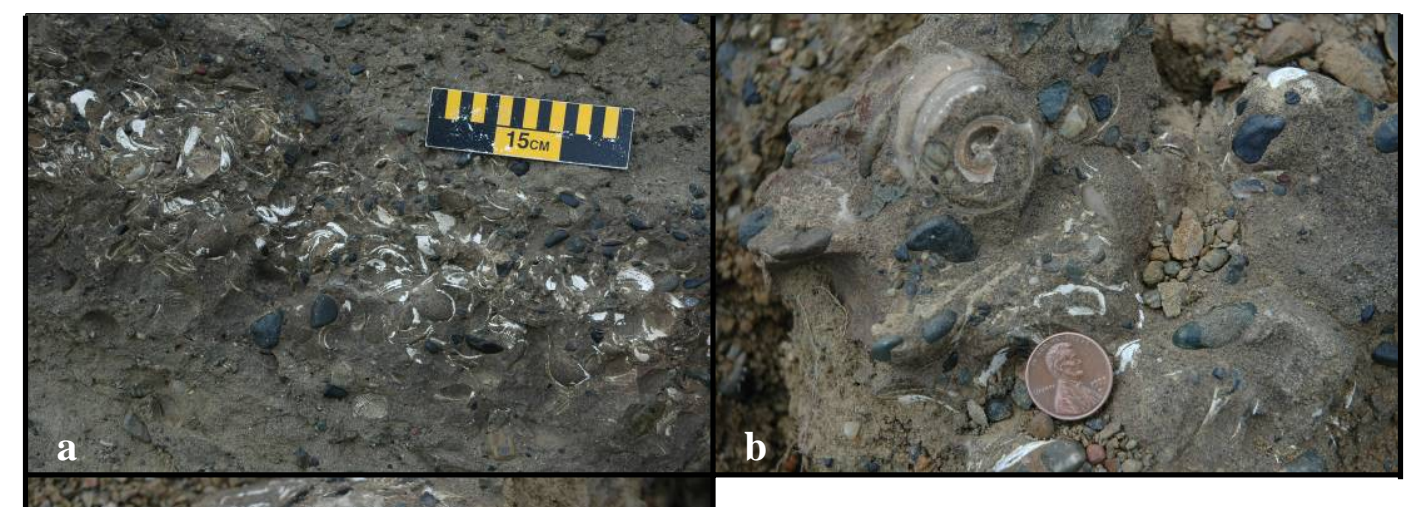

Figure 2.14. Marine megafossils and megafossil fragments are common in the upper Bear Lake 5 section. Clams ( $a$ and c) and gastropods (b) are the most typical megafossils found. 

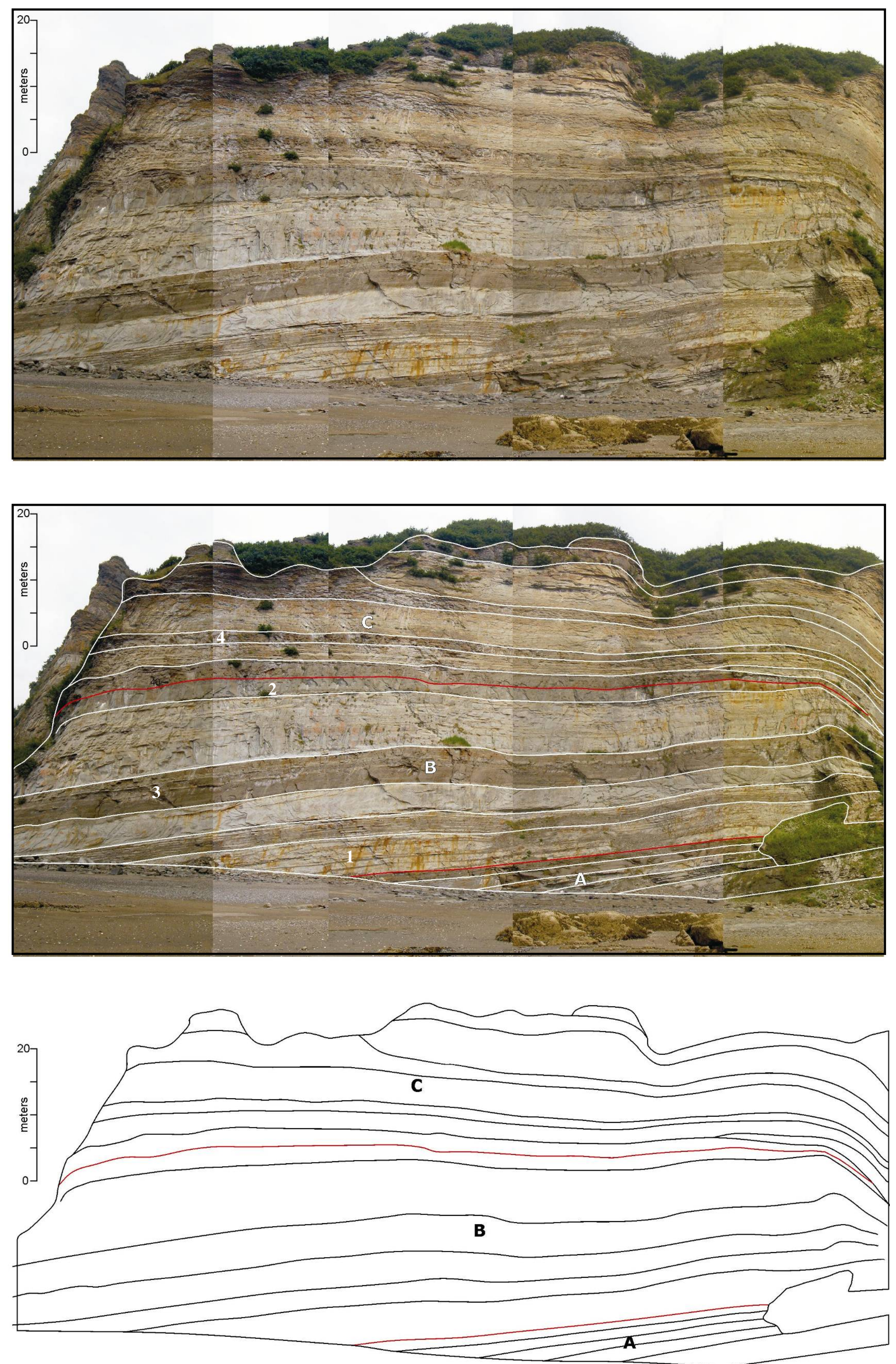

Figure 2.15. Photomosaic and line drawing interpretation for the Bear Lake Formation at the Sundean locality (view to the northeast). Three discrete packages are defined: (A) bioturbated sandstone and siltstone, (B) well-sorted sandstone with lateral accretion surfaces, and (C) flaser-and wavybedded sandstone. See text for key to numbers. 


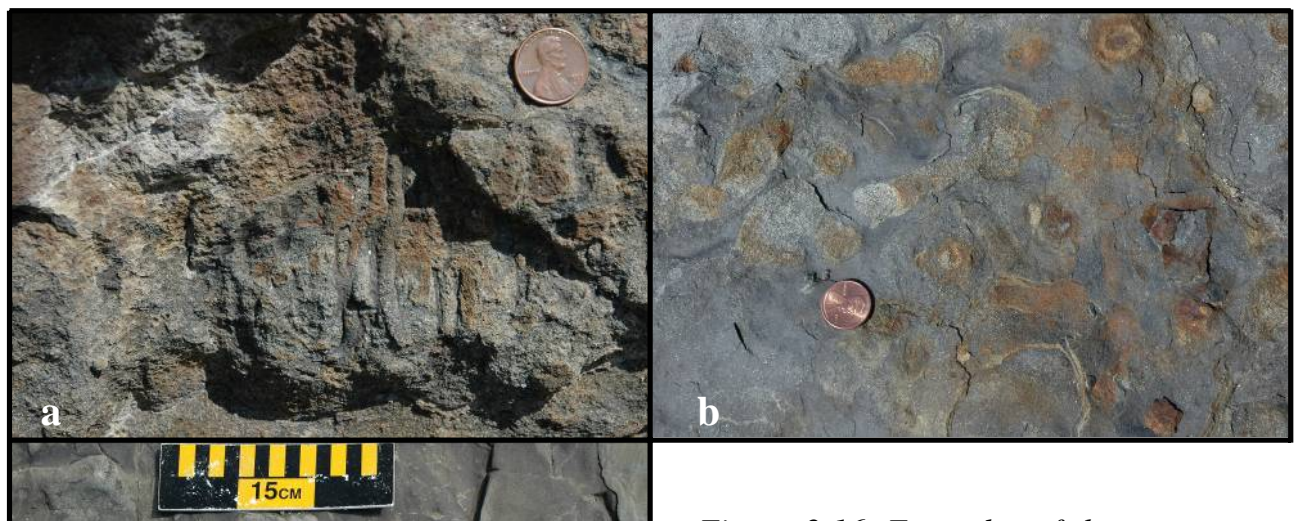

Figure 2.16. Examples of the most common trace fossils found at the Sundean locality. (a) Arenicolites in cross-sectional view, (b) probable Diplocraterion in plan view, and (c) Planolites in plan view.

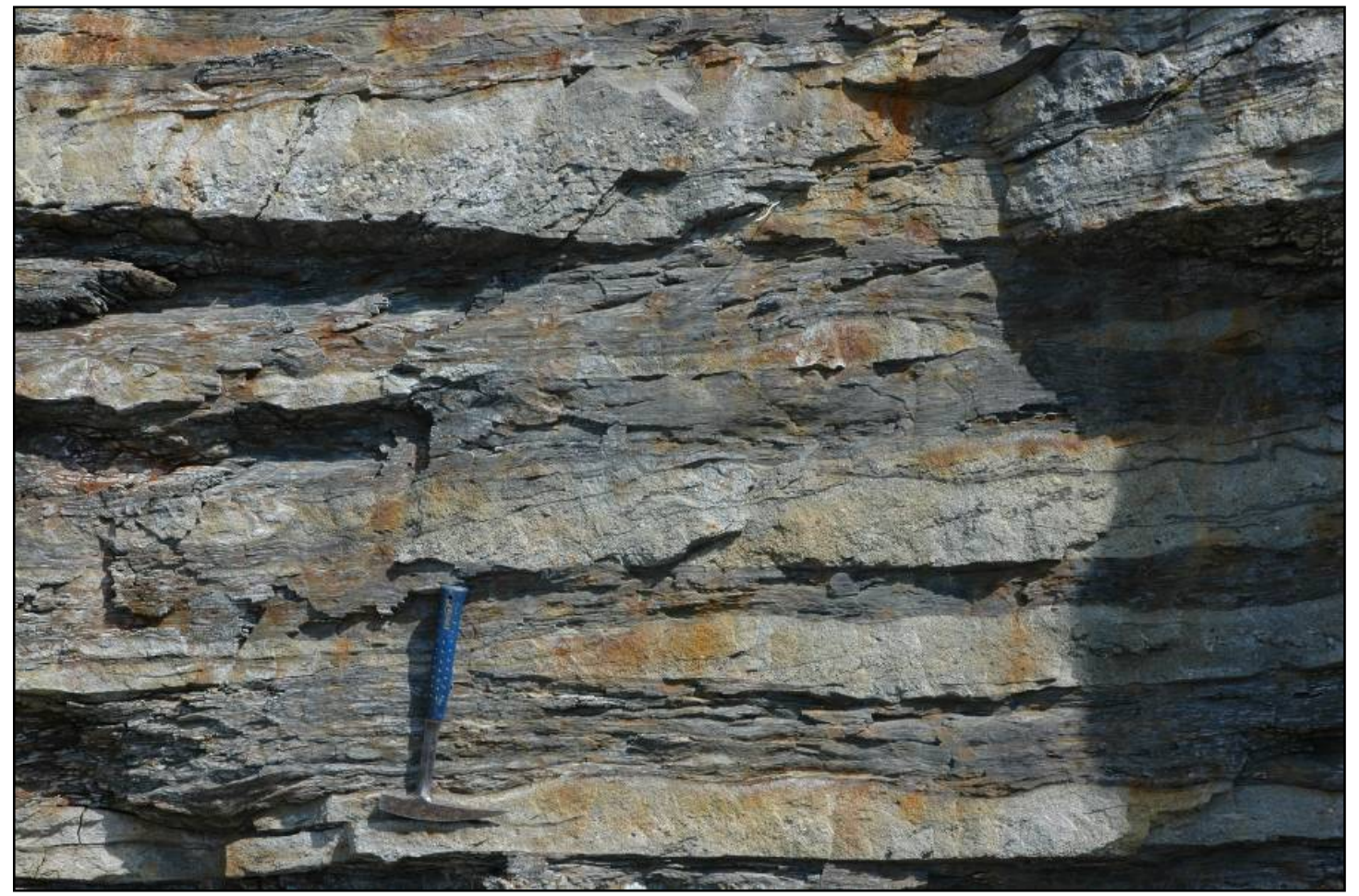

Figure 2.17. Flaser-bedded sandstone interbedded with very coarse-grained sandstone and conglomerate in the lower part of the Sundean section. 


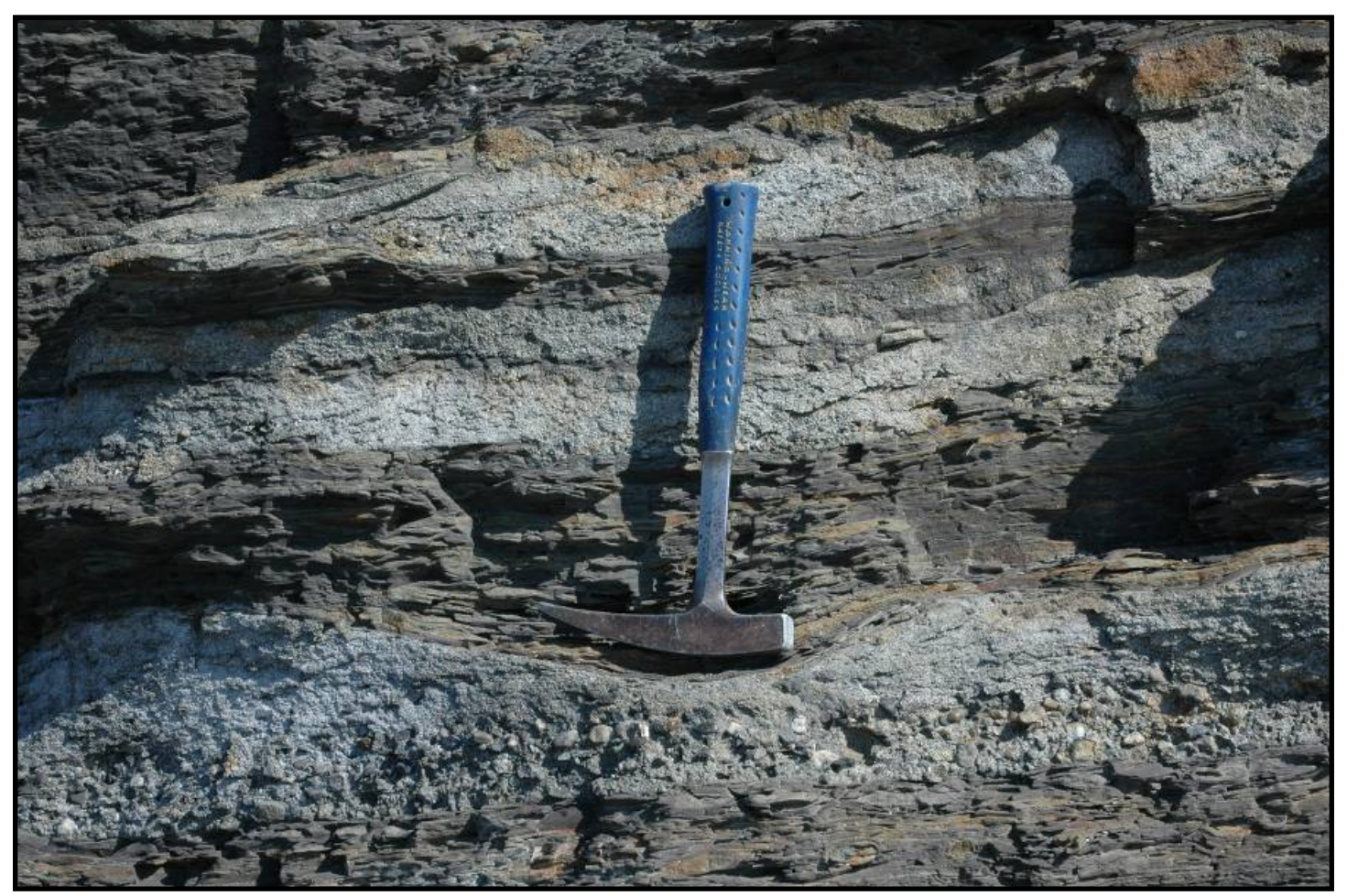

Figure 2.18. Individual conglomerate beds fine upward into flaser- and wavy-bedded sandstone in the middle part of the Sundean section.

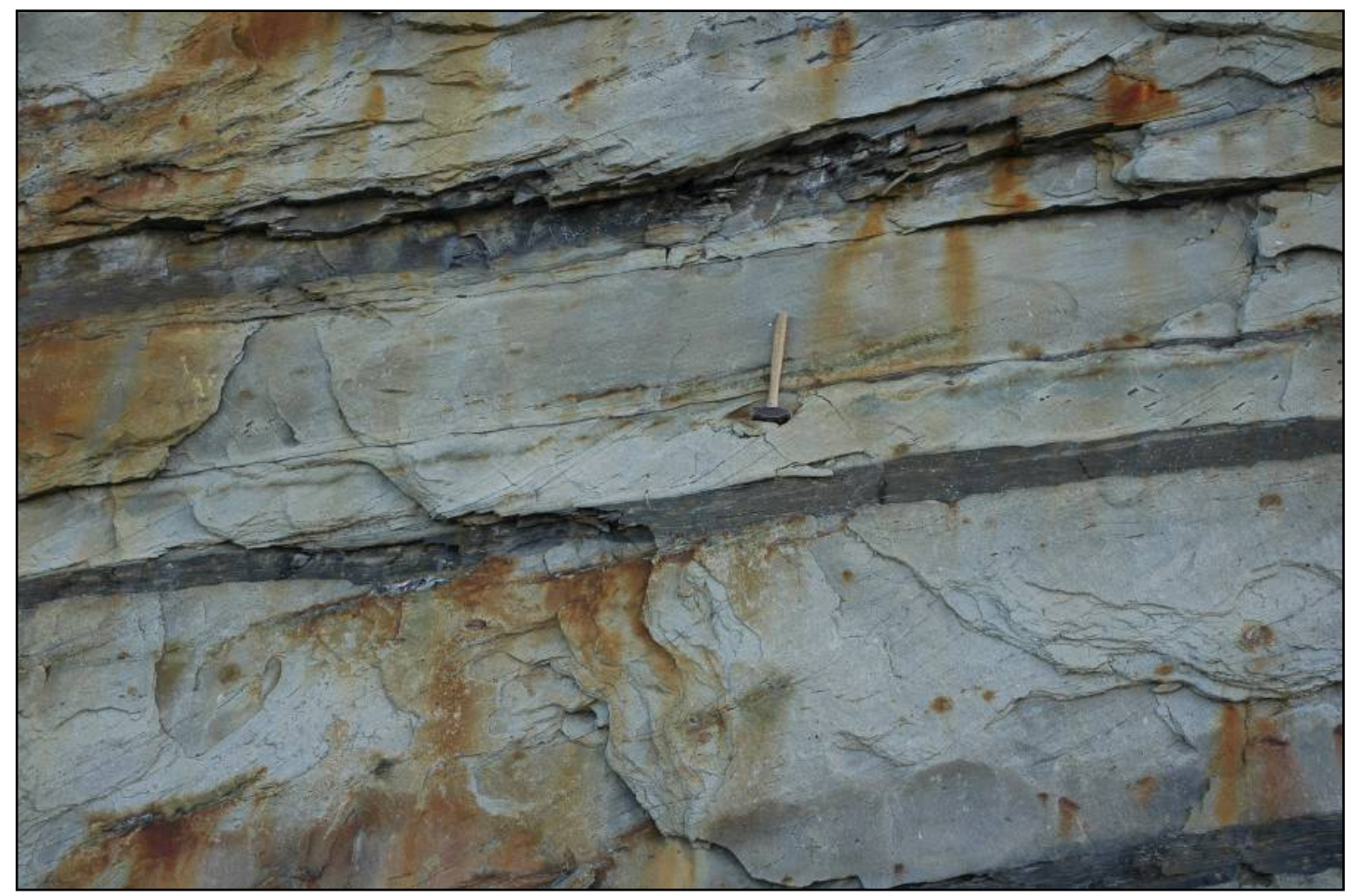

Figure 2.19. Well developed planar cross-stratification in the middle part of the Sundean section. Hammer in the middle of the photograph for scale. 


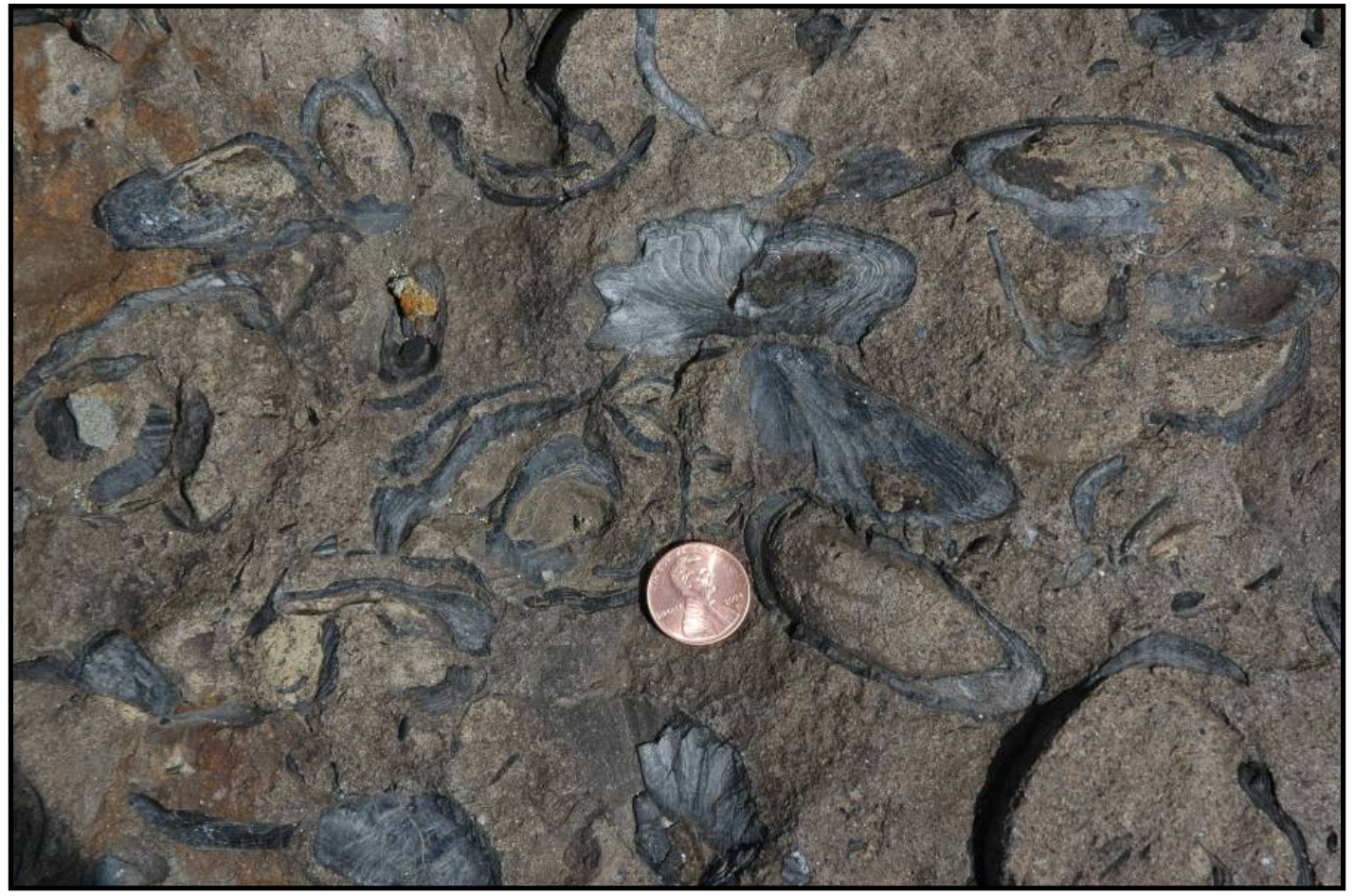

Figure 2.20. A thick sandstone package with abundant mussel fossils from the middle part of the Sundean section. 


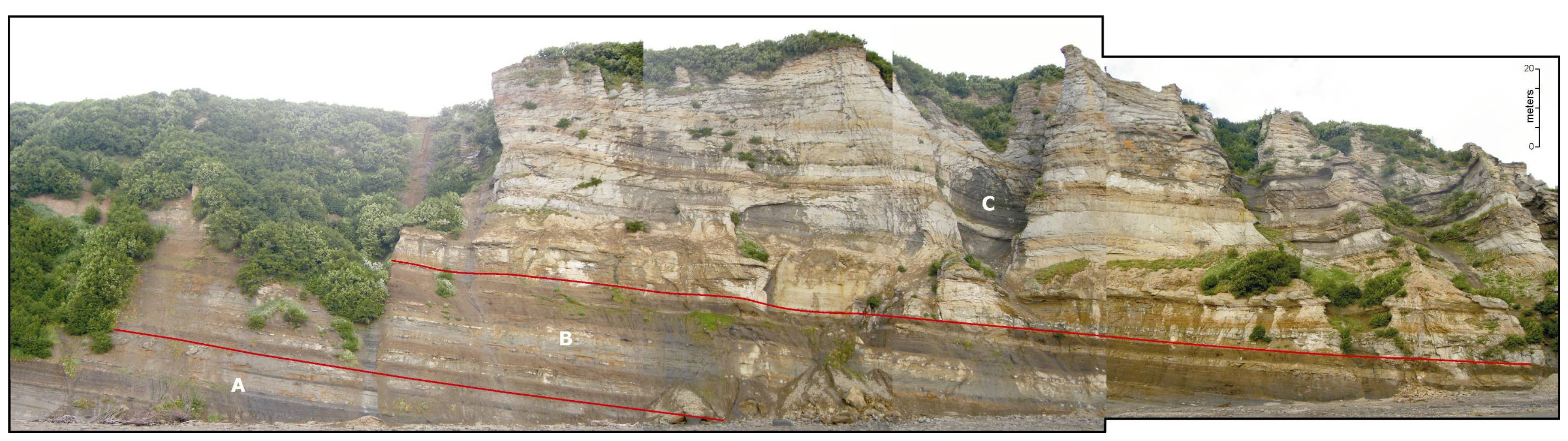

Figure 2.21. Photomosaic with line drawing interpretations for the Bear Lake Formation at the Left Head locality (view to the northeast). Three discrete packages are defined: (A) thick sandstones with abundant coalified fragments and a lack of bioturbation, marine macrofossils, and mud drapes on foresets, (B) interbedded flaser-, wavy-, and lenticular-bedded facies, and (C) thick, bioturbated sandstones. 


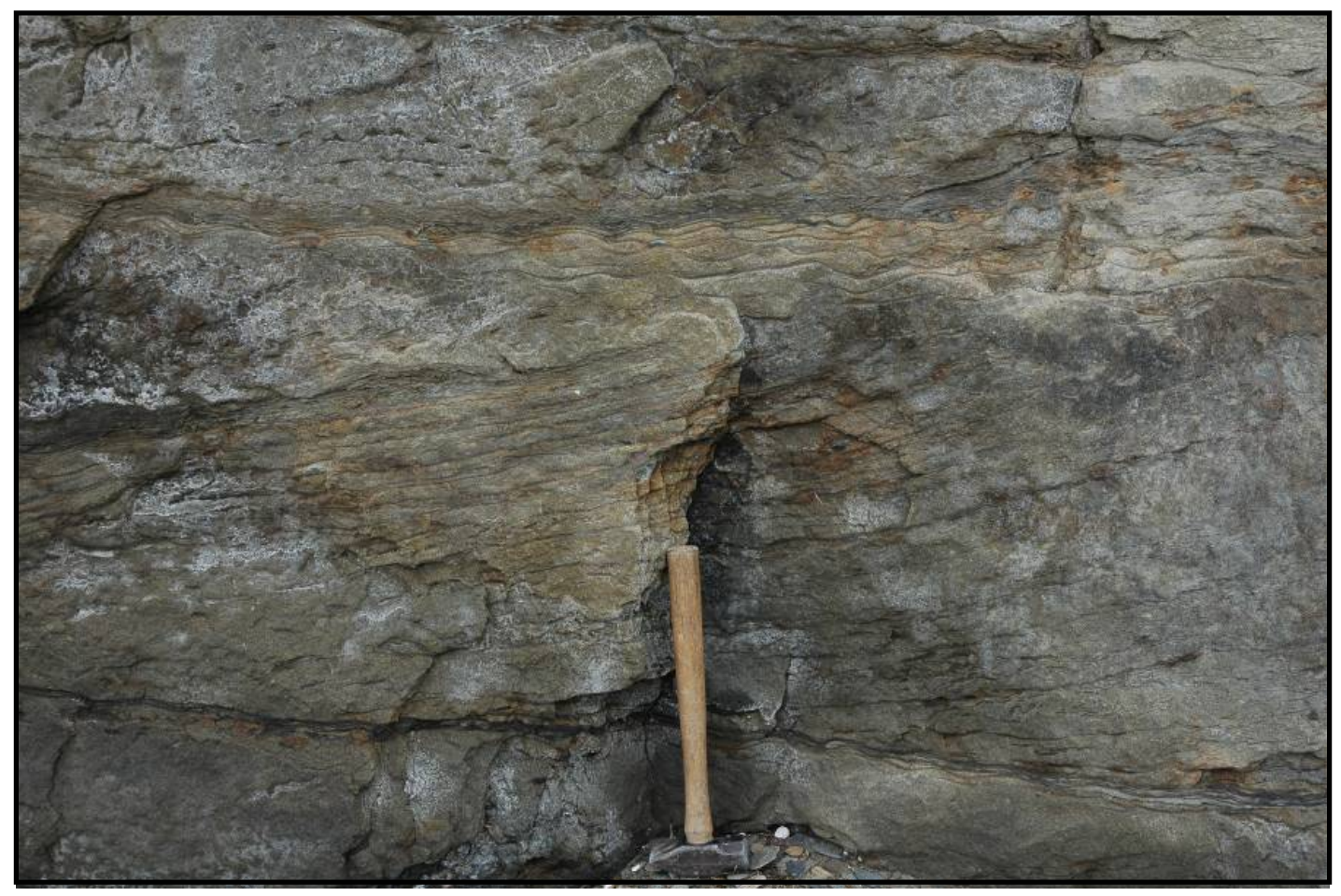

Figure 2.22. Cross-stratified sandstone with thin mudstone drapes from the middle part of the Left Head section (Bear Lake Formation).

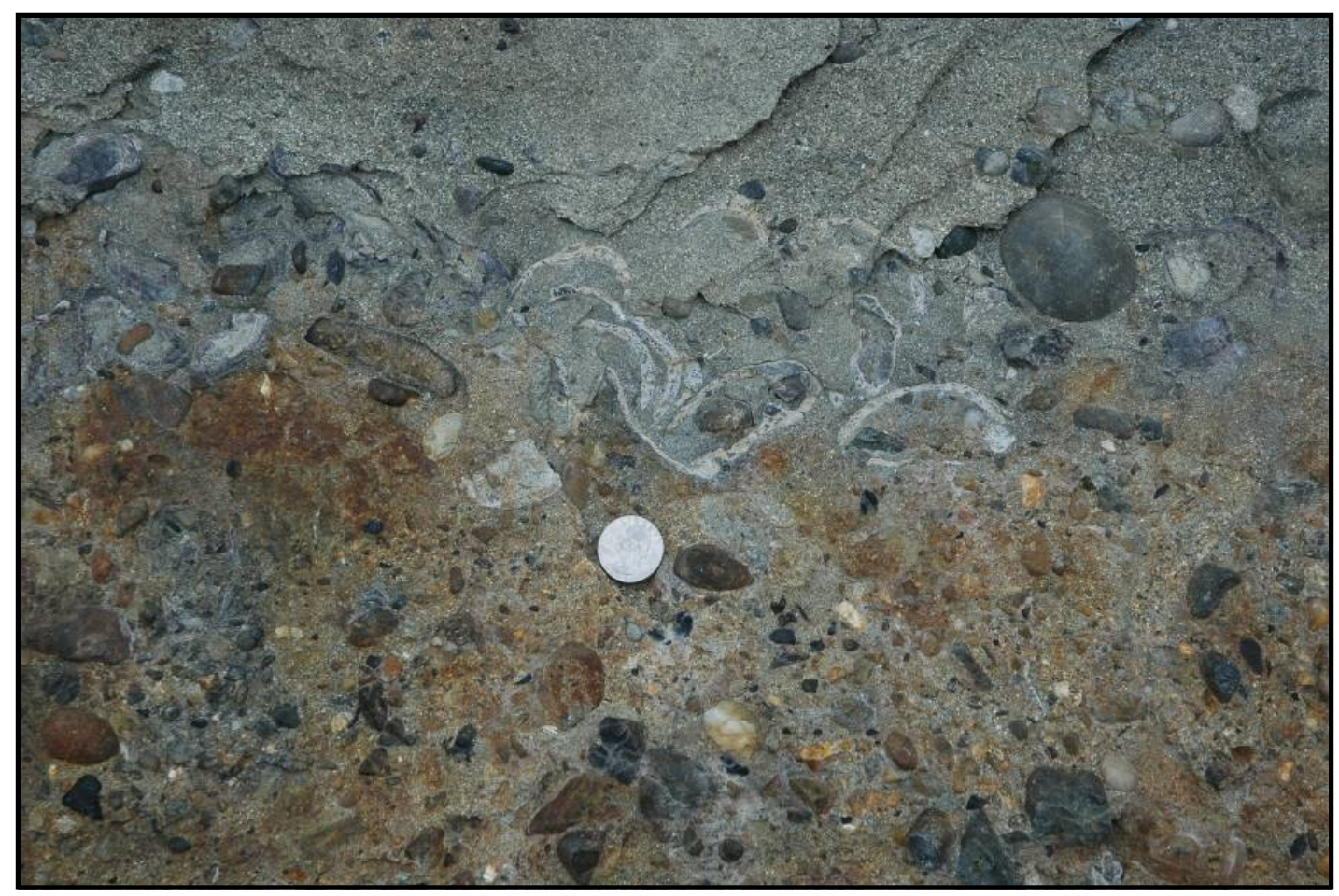

Figure 2.23. Disarticulated marine macrofossils in a conglomerate horizon in the Left Head section (Bear Lake Formation). 


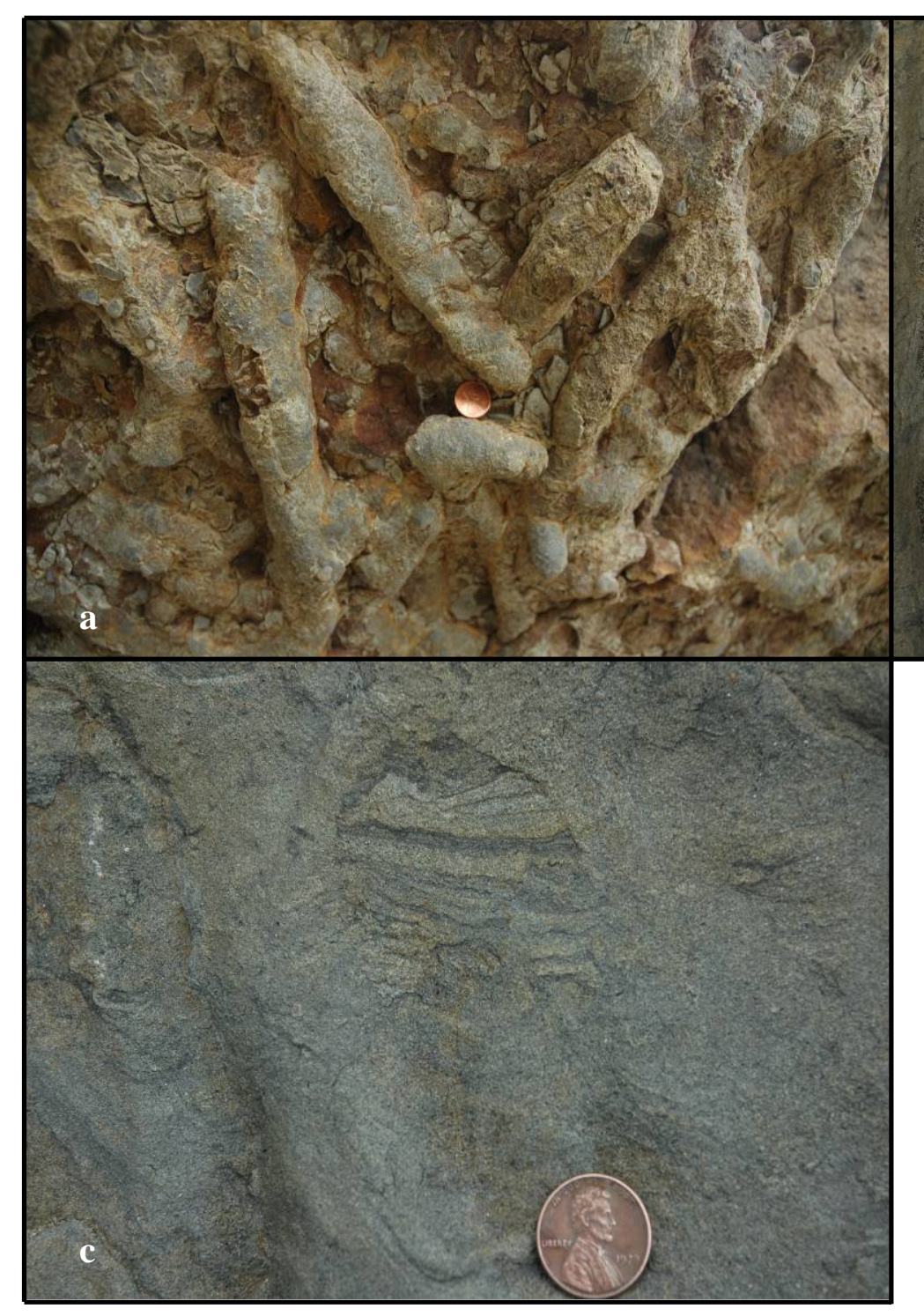

Figure 2.24. Examples of the diverse and abundant trace fossil assemblage in the upper part of the Left Head section (Bear

Lake Formation). (a) Thalassinoides, (b) unidentified, segmented, vertical shaft (skolithos assemblage), and (c) crab burrow. 


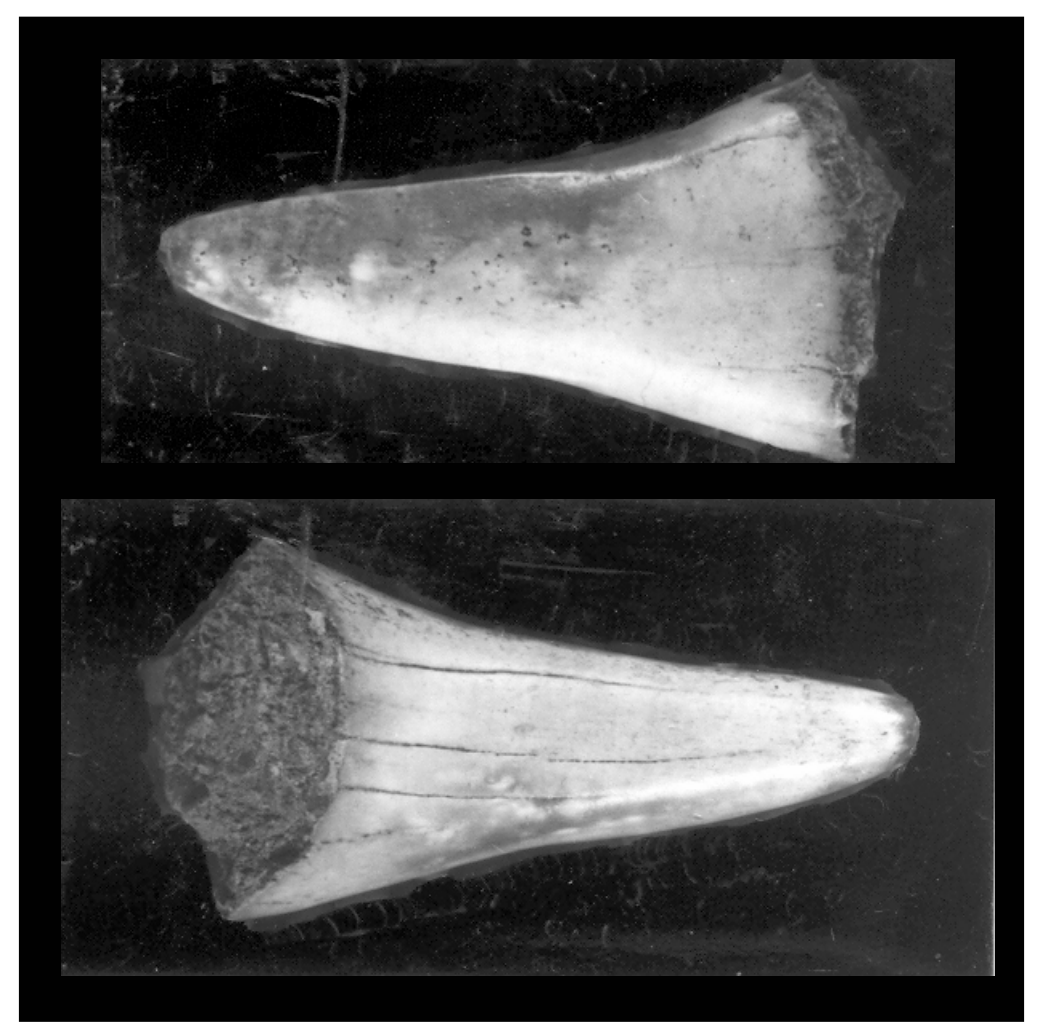

Figure 2.25. A shark tooth found in the upper part of the Bear Lake 2 measured section: (Top) front view, (bottom) rear view. Magnification x2, approximate height of tooth: $2.85 \mathrm{~cm}$.

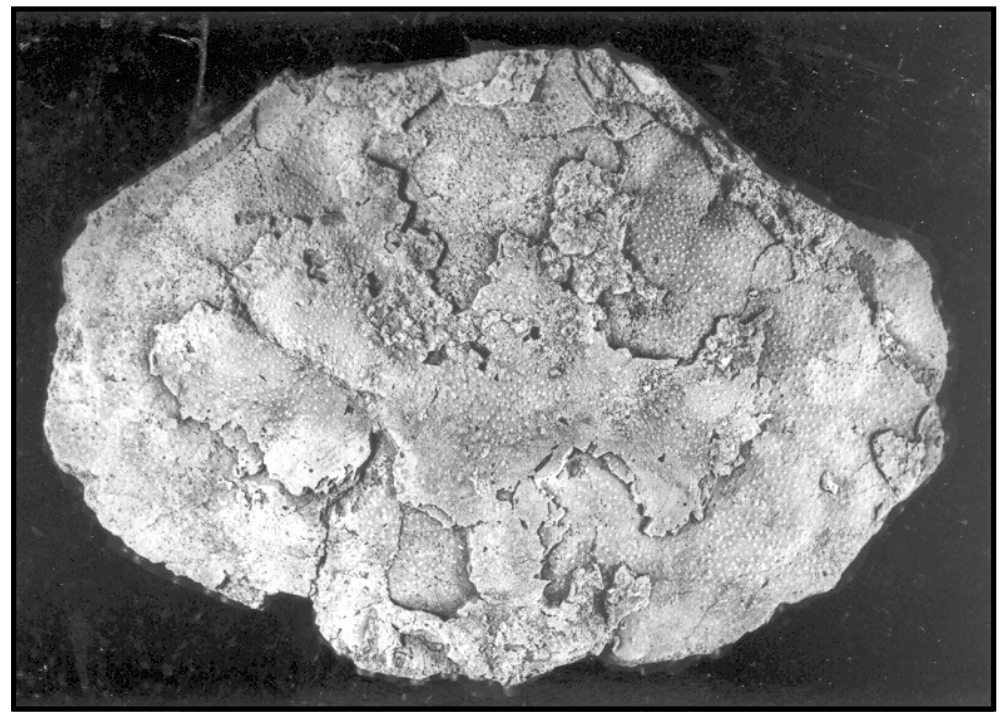

Figure 2.26. Crab carapace recovered from the upper part of the Bear Lake 2 measured section. Magnification x1. 
Section III. Outcrop Distribution of the Miocene-Pliocene Unconformity and Character of Associated Deformation in the Bear Lake Formation

By P.L. Decker

Previous field work (Burk, 1965; Wilson and others, 1999; Finzel and others, 2005a and b) recognized the potentially significant and locally strongly angular unconformity separating rocks now assigned to the Miocene Bear Lake and Pliocene Milky River formations. This unconformity is discernible in seismic data offshore in Bristol Bay as a more subtle truncation and downlap surface (Finzel and others, 2005a and b). Goals for the 2005 field season included documenting the outcrop distribution of the unconformity and interpreting the structural event(s) leading to its development. This report presents a reconnaissance geologic map of the unconformity along with structural measurements and kinematic observations, and outlines a gravitational spreading hypothesis to explain the associated deformation.

The Miocene-Pliocene unconformity is intermittently exposed over a distance of at least $24 \mathrm{~km}$ on several ridges south and east of Bear Lake (fig. 3.1). Additional exposures of the equivalent contact farther west toward Herendeen Bay were mapped by Wilson and others (1999), but were not examined or mapped in 2005. The unconformity is recognized by contrasts in color, lithology, topography, and in many locations, structural attitude. The Bear Lake Formation is dominated by interbedded buff, orange, brown, and olive gray weathering sandstones that typically form smooth, steep slopes and occasional cliffs. Bedding varies from nearly horizontal to vertical below the unconformity. The Milky River Formation contains abundant light gray to white weathering tuffaceous sandstones, and light tan to orange tuffs, which, where interbedded with dark andesite and basalt flows, commonly form sheer cliffs.

Where examined during the 2005 field season, structural discordance at the Miocene-Pliocene unconformity ranges from negligible to profound. An unusually broad spectrum of structural styles is recognized at different structural levels. Deeper structural and stratigraphic levels of the Bear Lake Formation consist of mostly intact strata that vary from sub-horizontal to variably northwest dipping. Shallower structural levels are moderately to intensely deformed by (1) low-angle slip surfaces with both normal and thrust displacements, (2) steeply dipping slip surfaces with minor normal, reverse, and strike-slip offsets, (3) variably oriented open to isoclinal folds, and (4) chaotically dismembered domains. Flow fabrics and liquefaction features are present in more intensely deformed intervals, consistent with deformation in an unlithified, but semi-consolidated state. Fold axis orientations, fold asymmetries, and the sense of movement on thrust and low-angle normal detachments consistently indicate top-tonorthwest transport, approximately parallel to the dip direction of underlying, intact Bear Lake strata. This complex deformation is hypothesized to relate to uplift and tilting of the higher terrain to the southeast, with most of the faulting, folding, and dismemberment occurring by gravitationally driven spreading of shallow structural levels toward the northwest, away from the axis of tectonic uplift where older Tertiary and Mesozoic units are exposed to the southeast (Burk, 1965; Wilson and others, 1999).

Figure 3.2 shows folds and low-angle normal and thrust faults that characterize the updip portion of the gravitational spreading complex. These exposures are located in the southern part of T48S, R69W, high on the southeastern end of an unnamed ridge, here informally referred to as "Milky Ridge" (fig. 3.1). The deformed zone is floored by a basal detachment fault that runs bedding-parallel over a significant distance before ramping downsection (fig. 3.2c). A complex array of low-angle faults overlies this decollement, forming a top-to-northwest extensional duplex in the uppermost portions and exhibiting northwest-verging thrust faults and recumbent drag folds in slightly downdip portions.

On much of this ridge, the lower Milky River Formation is also internally folded, faulted, and chaotically dismembered, forming megabreccias that are more complexly disrupted than the subjacent Bear Lake. Locally, the unconformable contact appears to be offset or folded, with incorporation of the upper portions of the Bear Lake in the Milky River chaotic zone (fig. 3.3). In places, the unconformity appears to have behaved as a detachment surface (fig. 3.2b). Nonetheless, the fact that the contact is a strongly angular and undisturbed unconformity elsewhere argues persuasively that the disturbances of the Milky River and Bear Lake deformed zones occurred as independent events, though probably both as responses to gravitational instability.

Several miles to the northeast, the western slopes of the informally named "Sandy Ridge" (Sections 4, 5, 9, and 10, T48S, R6W; fig. 3.1) provide a series of exposures of the Bear Lake deformed zone in a northwest-oriented traverse, approximately parallel to the inferred transport direction. Farthest updip to the southeast, the most prominent structures are north-northwest-vergent thrust faults and associated gently east-northeast-plunging drag folds (fig. 3.4). Steeply-dipping and low-angle normal faults, and minor reverse and strike-slip faults are also present. Pervasive flow features demonstrate that the deformed beds remained largely coherent, but deformed in a plastic 
state. Though not evident in figure 3.4, a radical change in dip direction is present near the eastern edge of the exposure, caused by scissors-type rotation on a steep northwest-striking fault.

Figure 3.5 depicts a large exposure spanning several spurs of Sandy Ridge (fig. 3.1) approximately $0.8 \mathrm{~km}$ downdip of the location in Figure 3.4. Here, an intraformational angular unconformity within the Bear Lake Formation truncates the underlying severely deformed interval and is capped by boulder conglomerates and an intermediate-composition tuff breccia unit. This unconformity was subsequently tilted to the north-northwest before being erosionally beveled and overlain by marine sands of the Milky River Formation. The deeper, intensely deformed interval includes patchy remnants of coherent conglomerate and sandstone beds, but most of this exposure consists of a jumble of chaotically dismembered and contorted blocks ranging from a few meters to a few tens of meters across. Remnants of an interbedded coal and tuff interval scattered throughout the exposure define numerous floating fold hinges, most of which plunge to the northeast. A marker horizon in the more coherent strata defines two different gently plunging, steep-limbed, isoclinal anticlines; this folded marker bed may be imbricated by thrust faults rotated into steep dips during late stages of the deformation.

The speculative thrust faults shown in Figure 3.5 are consistent with better exposed faults that imbricate a series of correlatable beds in another exposure just more than a mile farther northwest shown in Figure 3.6 (fig. 3.1). At this location, the subhorizontal Miocene-Pliocene unconformity is capped by a nearly $2 \mathrm{~m}$ thick boulder conglomerate unit, and truncates a nearly vertically dipping, fault-repeated succession of sandstone, coal, and tuff beds. The isoclinal folds defined by the coals plunge moderately to the northeast, and are clearly drag features formed by fault repetition of the correlated beds. Assuming these faults formed as imbricate northwest-verging thrusts, they must have been rotated to their current very steep dips as deformation progressed. One possible explanation for this is backward rotation of an imbricate fan with numerous horses stacked up farther northwest, toward the compressional toe of the gravitational spreading complex.

A stereoplot of fold axes observed in the three exposures from Sandy Ridge depicted in Figures 3.4-3.6 is shown as Figure 3.7. Given the limited number of observations, there is variability in the plotted orientations, but a strong clustering of folds around the mean vector, which plunges 59 degrees to azimuth 046, is still apparent. The interpreted northwest-directed gravitational spreading of the upper structural levels is supported by (1) the fold asymmetry, (2) the observed sense of movement on both low-angle normal and thrust faults, and (3) the widespread northwest dip of intact Bear Lake Formation. As noted earlier, this sense of structural transport is away from the axis of uplift in the core of the Miocene-Pliocene arc. At present, it is unknown whether this tectonic style is symmetric, with similar deformation with the opposite sense of movement occurring on the southeastern flank of the range.

Rates and mechanisms of this shallow gravitational spreading are presently not well constrained. Because the sediments were only partially consolidated during deformation, they were capable of failure in either brittle (slip) or plastic (flow) modes, depending on confining stress, pore fluid pressure, and strain rate. Deformation might have occurred rapidly in just a few catastrophic mass wasting events, or accumulated gradually over dozens of seismic episodes, or by continuous processes that progressed at creep rates. At least one, and possibly several intraformational angular unconformities are present in the Bear Lake Formation (figs. 3.8a-c), and similar erosional truncations are observed in the Milky River Formation (fig. 3.8d), indicating that tilting and associated deformation may have been part of an ongoing geologic process that continued well into Pliocene time.

The uplift and tilting of the deeper structural levels must have been tectonically driven, and may have involved compressional or transpressional uplift along with the Late Miocene to Early Pliocene plutonic emplacement described by Wilson and others (1999). It is unclear from current field observations how this uplift in or near the magmatic arc relates to coeval subsidence in the back arc during late Miocene time to Pliocene time, and whether this tectonism generated traps prospective for oil and gas exploration beneath the Bristol Bay lowlands. Future field investigations in the area should focus on defining structural attitudes and relationships in deeper structural levels and older units in an effort to shed light on these questions. 


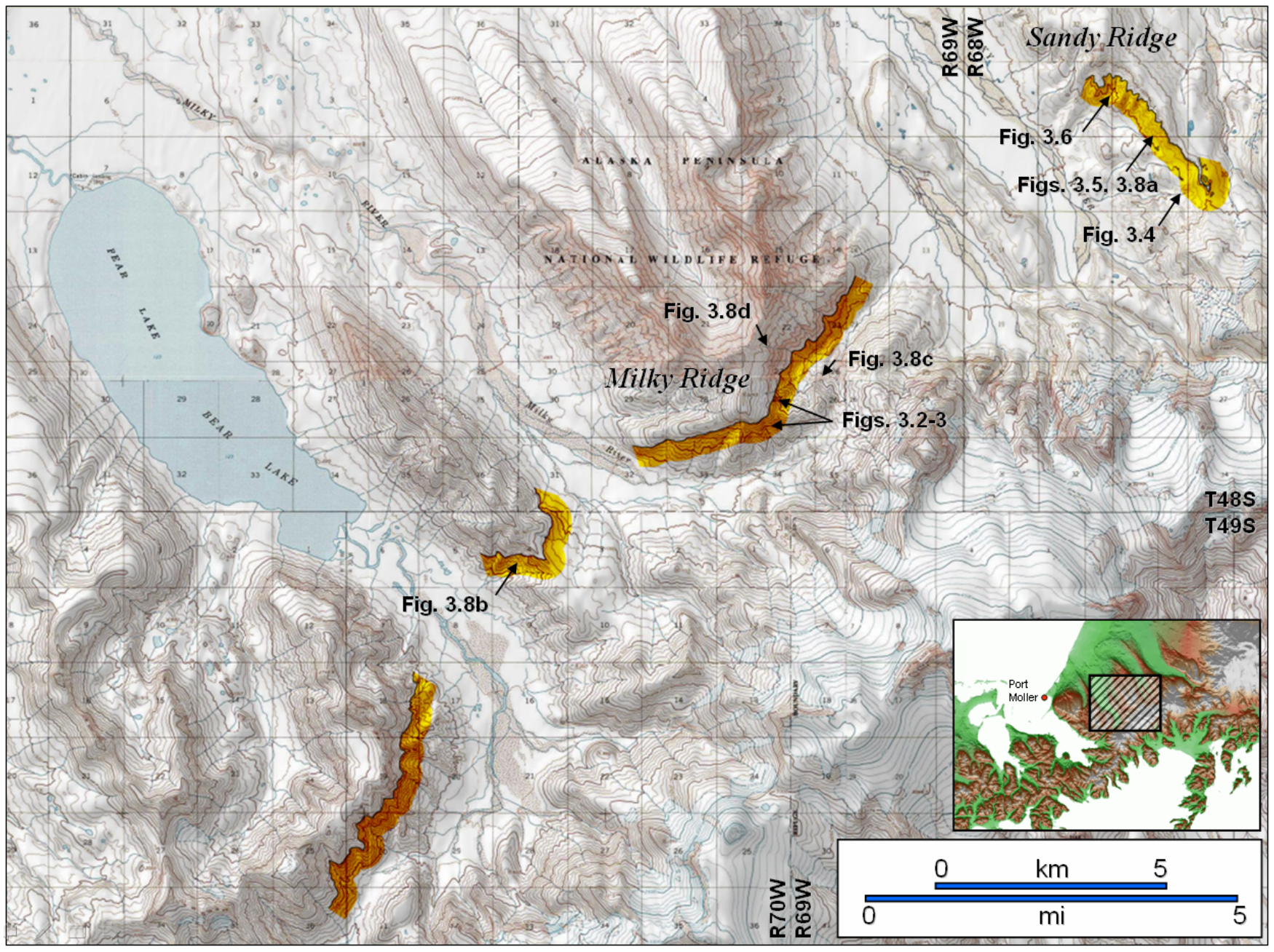

Figure 3.1. Reconnaissance geologic map showing distribution of Mio-Pliocene unconformity exposures examined during 2005 field season. The unconformity is highly angular in exposures east of Bear Lake where deformation of the underlying Bear Lake Formation varies from moderately NW-dipping homoclinal panels to intensely faulted, folded, and chaotically dismembered domains. Milky Ridge and Sandy Ridge are informal names used in text. Numbered squares are 1 square mile sections. 

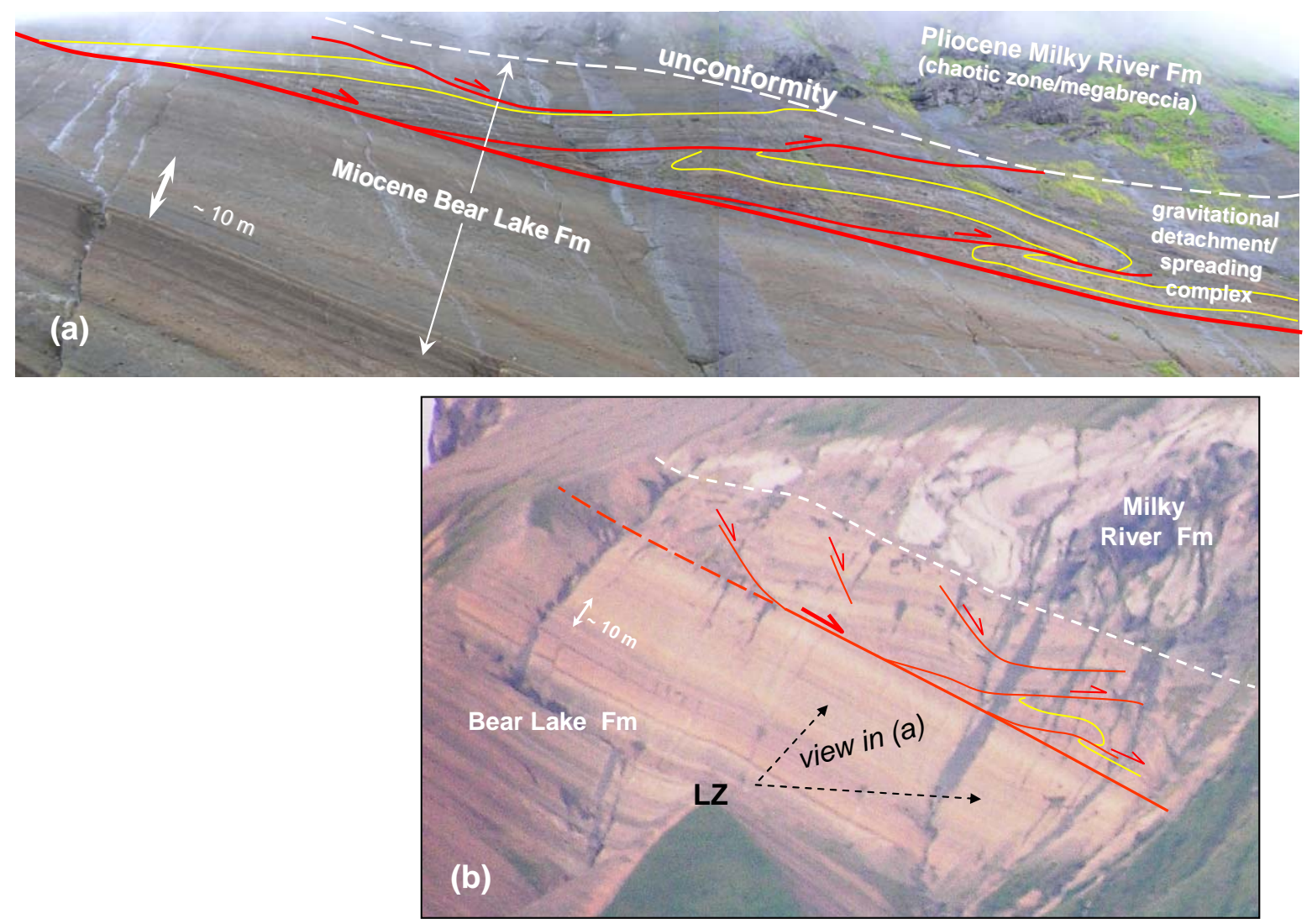

Figure 3.2. Annotated photos of the gravitational spreading complex with top-to- $N W$ transport developed in coarse, marginal marine clastics of the upper Bear Lake Formation below the Miocene-Pliocene unconformity (fig. 3.1). Because of perspective in photo (a), thicknesses are somewhat foreshortened and the irregular appearance of the unconformity is misleading. Photo (a), taken from the ground looking sharply upslope to the WNW from landing zone vantage point [see "LZ" in photo (b)]. Photo (b) is a long-distance telephoto view to the SW along strike, and shows more accurate relationships, but at lower resolution. In both images, a zone of internally truncated, folded, and imbricated beds overlies a moderately NW-dipping, bedding-parallel basal detachment (heavy red line), and is truncated just below the resistant cliffs of Milky River Formation megabreccia, themselves internally folded and disrupted by later downslope depositional or mass wasting processes. Most of the Bear Lake strata maintain their general coherence here, consistent with a position in the updip portion of the spreading complex. The spreading process is extensional overall, but internal compressional overlap may result from frictional variations within the spreading mass. Exposures are at head of unnamed drainage at $55.998^{\circ} \mathrm{N}, 160.03^{\circ} \mathrm{W}$, Section $27, \mathrm{~T} 48 \mathrm{~S}, \mathrm{R} 69 \mathrm{~W}$. 


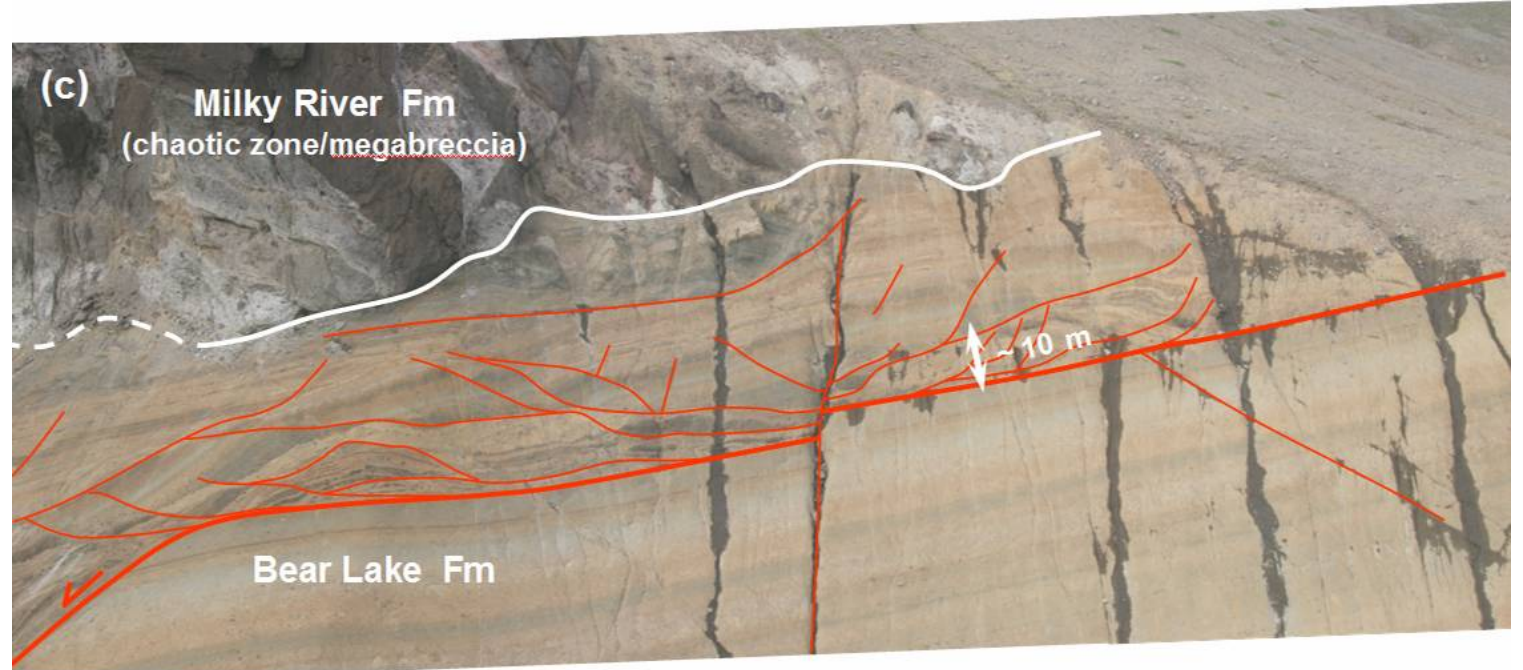

Figure 3.2, continued. (c) View looking approximately northward at details of faulting in oblique cross section through updip portion of gravitational spreading complex approximately $0.3 \mathrm{mi} \mathrm{SW}$ of exposures in photos (a) and (b), in SW part of Section 27, T48S, R69W. The low-angle normal basal detachment fault is bedding-parallel at right, and ramps downsection at left through intact Bear Lake strata. Hangingwall units are complexly faulted, forming a well developed extensional duplex. In this oblique section, apparent offset is to both right and left, but actual slip is away from the viewer and to the left. 


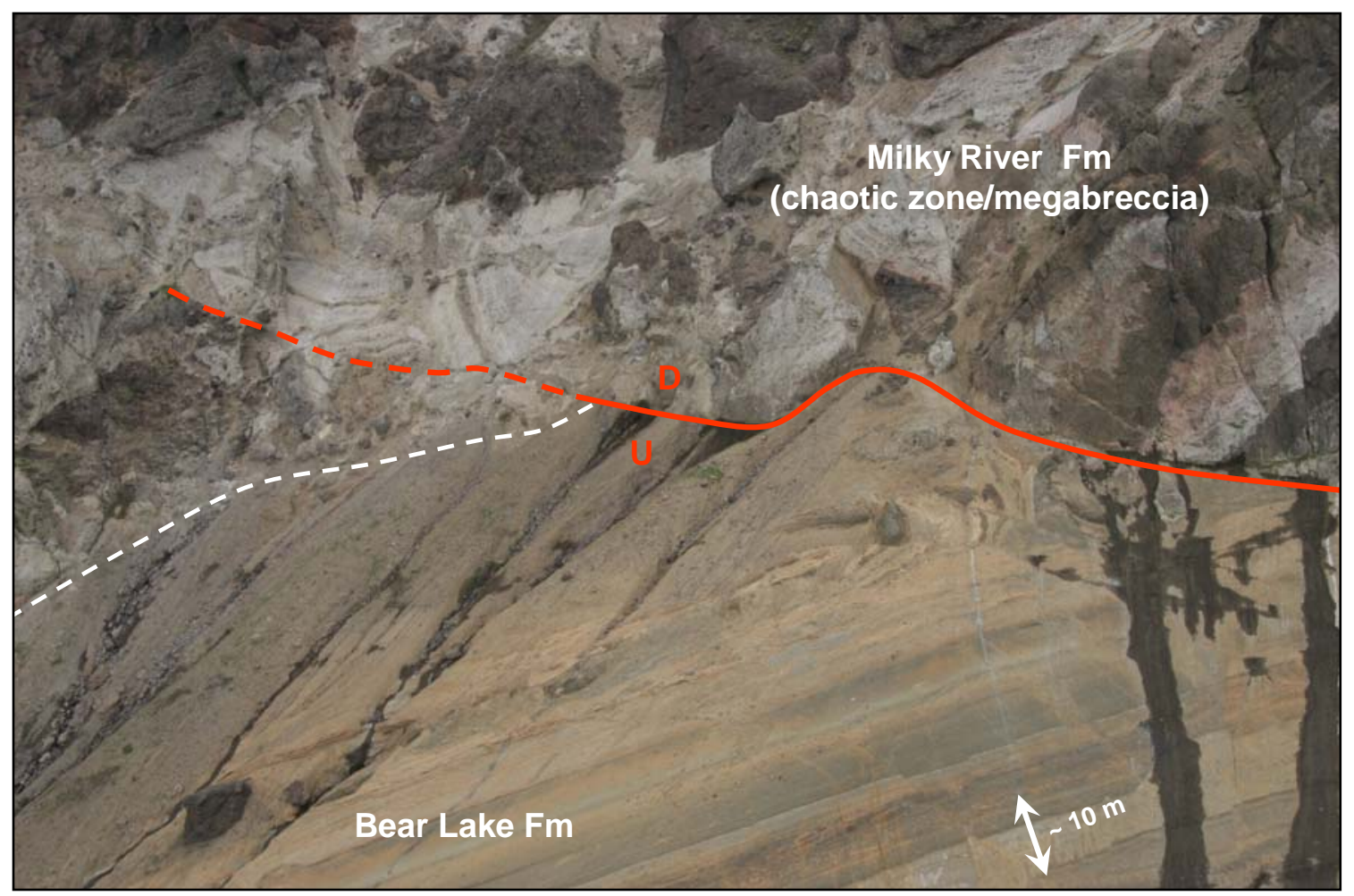

Figure 3.3. View looking north at disrupted contact between faulted but less severely disrupted Bear Lake and the overlying chaotic megabreccia of the Milky River Formation, immediately west of detachment ramp shown in figure 3.2c. The unconformity is offset by faulting, and part of the underlying Bear Lake Formation may be caught up in the chaotic disruption of the overlying Milky River. 


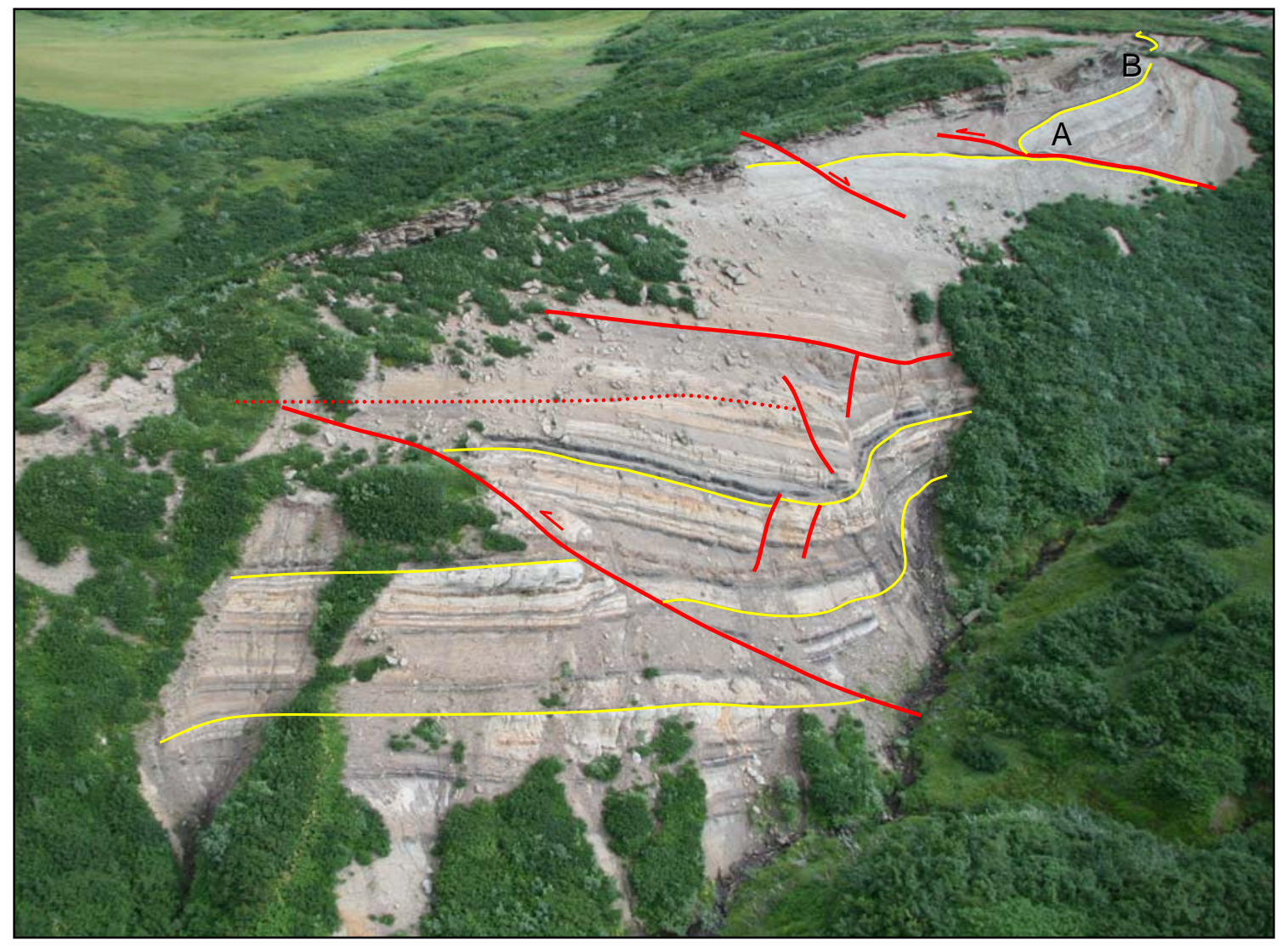

Figure 3.4. View to north near updip end of gravitational spreading complex. Thrust faults coexist with low-angle and steep normal faults. Asymmetric drag folds of different scales at "A" trend between $061^{\circ}$ and $080^{\circ}$, and plunge $1-16^{\circ}$ ENE, indicating top-to-NNW transport (into the page and to the left), generally consistent with fold vergence observations in other exposures. Conglomerates at "B" at top of exposure strike $055^{\circ}$ and dip $74^{\circ} \mathrm{NW}$. Exposures located at $53.037^{\circ} \mathrm{N}, 159.88^{\circ} \mathrm{W}$, Sections 9 and 10, T48S, R68W (see also fig. 3.1). 


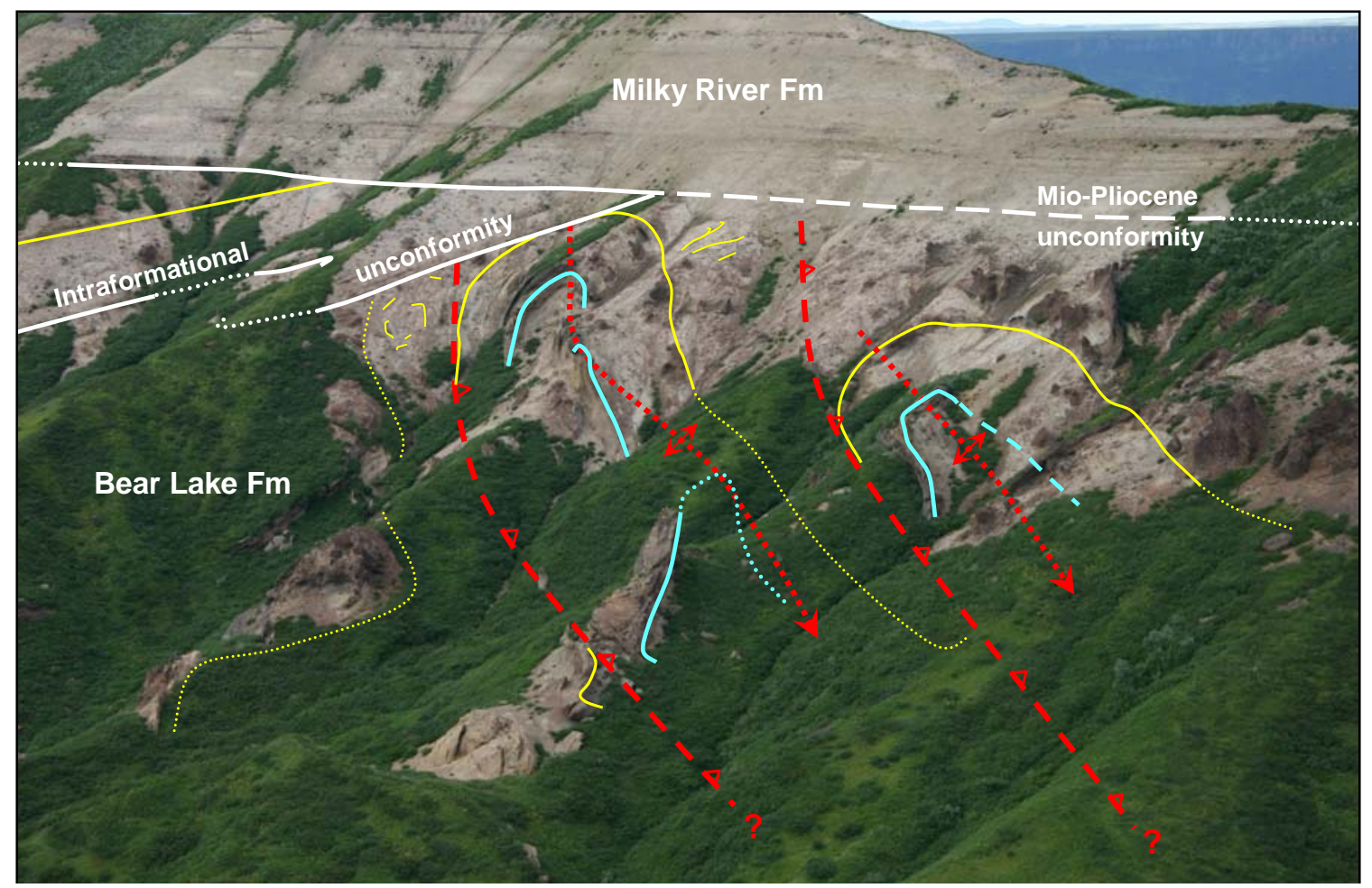

Figure 3.5. View to northwest of isoclinally folded and chaotically dismembered nonmarine strata of Bear Lake Formation overlain by a tilted but planar-bedded volcaniclastic and pyroclastic wedge of uppermost Bear Lake strata (above intraformational angular unconformity), all of which are unconformably truncated by marine sands and conglomerates of the Milky River Formation at the Mio-Pliocene unconformity. Blue line traces what is believed to be the same marker horizon on different spurs of the ridge (dashed where inferred, dotted where removed by erosion), defining two large, gently plunging anticlines with steep limbs. The anticline at center plunges approximately $10^{\circ}$ to azimuth 185 (SSW). Other bedding form lines are traced in yellow; intense dismemberment in much of the outcrop reduces traceable bedding to contorted blocks a few feet to a few tens of feet across. Dashed thrust faults are schematic, based on folding and repetition of the blue horizon, and are consistent with the style of imbrication observed in nearby exposures. These outcrops are inferred to be in the middle to distal reaches of the gravitational spreading complex. Photo is at $56.048^{\circ} \mathrm{N}, 159.89^{\circ} \mathrm{W}$, Sections 4 and 9, T48S, R68W (see fig. 3.1 for location). 


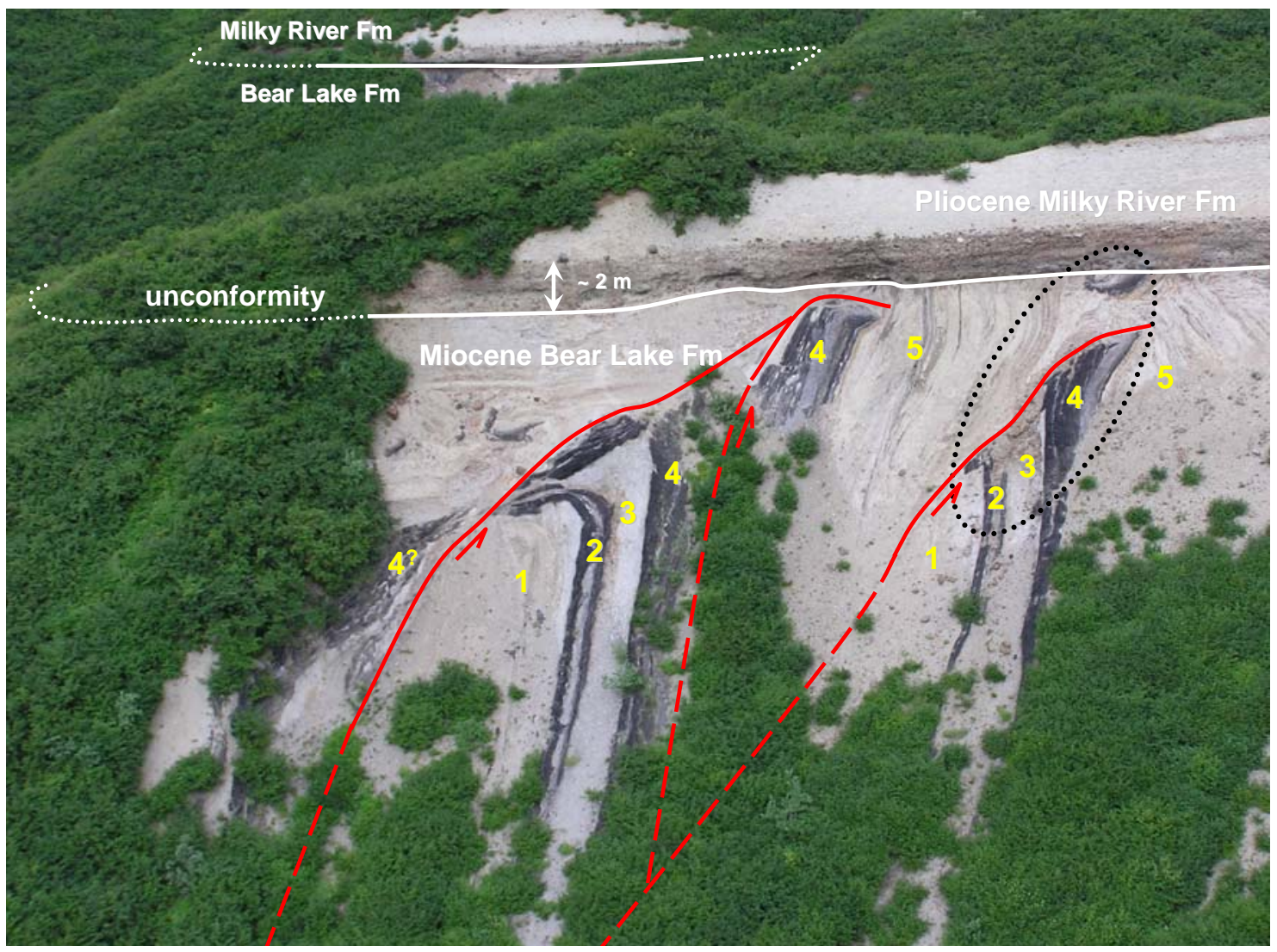

Figure 3.6. View to north of nearly vertical, imbricated coal horizons in the Bear Lake Formation overlain by boulder conglomerates of the Milky River Formation at the Mio-Pliocene unconformity. Correlatable beds are numbered in depositional sequence 1-5. Fold axes within dotted ellipse trend between $010^{\circ}$ and $028^{\circ}$ and plunge 5-44 NE. Interpreted faults and drag folds may have formed as top-to-NNW thrusts at much lower dip angles, with subsequent rotation to steep dips. The intensity of deformation and subvertical fabric suggest locally high compressional strains, probably in the downdip reaches of the gravitational spreading complex. Photo is at $56.058^{\circ} \mathrm{N}, 159.90^{\circ} \mathrm{W}$, Section 4, T48S, R68W (see fig. 3.1 for location). 


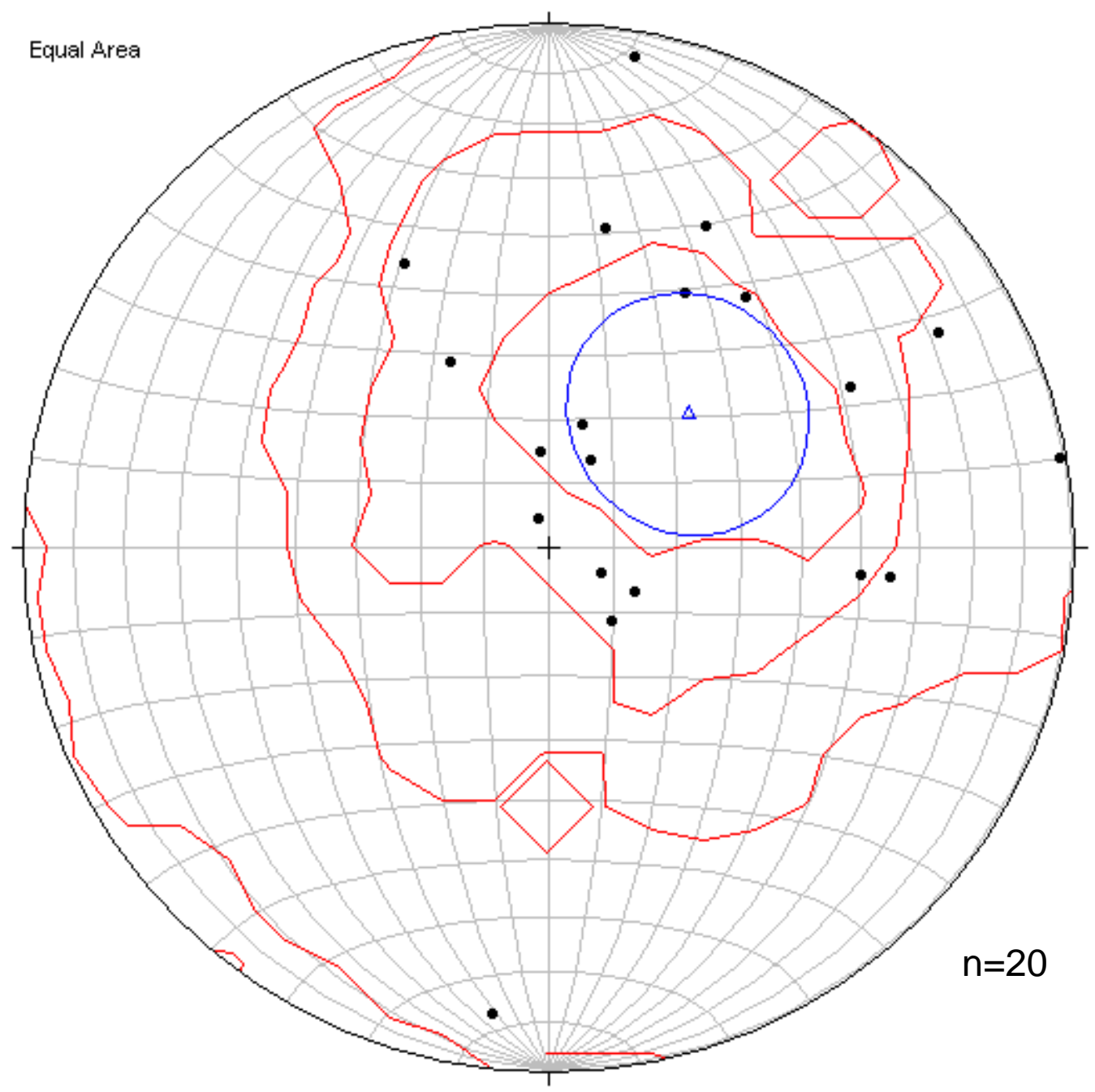

Figure 3.7. Stereoplot of Bear Lake Formation fold axes within the interpreted gravitational spreading complex. Plot shows measured fold axes (black dots), 2 sigma Kamb contours (red), and mean fold axis (blue triangle). Most folds plunge moderately to NE; mean fold axis vector plunges 59 degrees to azimuth 046, consistent with top-to-NW gravitationally driven transport away from the tilted and uplifted core of the Alaska Peninsula. Lower hemisphere, equal area projection using StereoWin 1.2 by $R$. W. Allmendinger. 

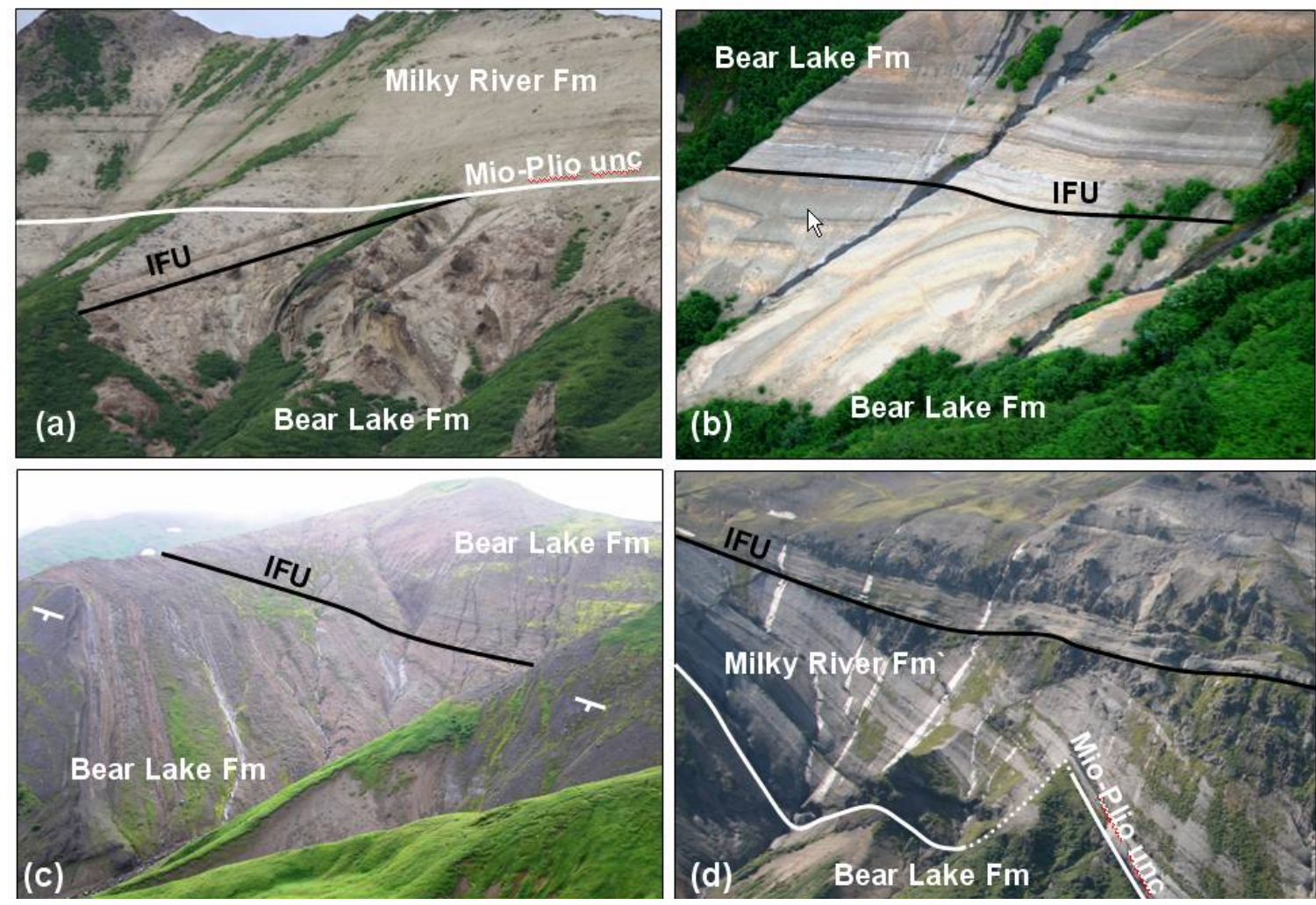

Figure 3.8. The occurrence of at least one, and perhaps several, intraformational angular unconformities (IFU) in the Bear Lake Formation $(a-c)$ and in the Milky River Formation (d) suggest that tilting and associated gravitational deformation were part of on an ongoing process that continued well into Pliocene time. 


\section{Section IV. Outcrop Structure of the Naknek and Bear Lake Formations, \\ Black Hills and Herendeen Bay \\ by P.L. Decker}

\section{Fracture Orientations in the Jurassic Naknek Formation}

A one-day reconnaissance of upland and coastal exposures of the Jurassic Naknek Formation in the Black Hills-Cathedral River area (fig. 4.1) revealed that bedding attitudes vary from nearly horizontal to a maximum dip of just over 30 degrees. This indicates that, although the Black Hills Uplift is interpreted as a major transpressional high (Worrall, 1991) with complex, en-echelon structures at its margins (Finzel and others, 2005a), structures at the crest appear to be broad, open folds. Although limited by exposure quality, future detailed mapping of these structures may succeed in evaluating closure and geometries of structural trap. The canyon of Steelhead Creek contains the easternmost outcrops in this area (fig. 4.1; Sections 26 and 35, T51S, R82W), where east-southeast dips of 1631 degrees define the eastward plunge of the Black Hills Uplift. A brief visit to the David River Zone (informal name) on the western shore of Herendeen Bay south of Coal Point also yielded surprisingly simple bedding attitudes in the Naknek Formation, despite the thrusting of Jurassic over Miocene units observed there (described in the following section).

Joints oriented nearly perpendicular to bedding are the most prominent structures in Naknek Formation outcrops in the southwestern portion of the lease sale area. Fracture orientation data can be useful for interpreting the structural history of rocks that contain few other visible structures, as well as for predicting fluid flow in fractured reservoirs. Figure 4.2 presents rose diagrams of fracture strikes[?] collected in the Black Hills and western Herendeen Bay outcrops. Nearly all the fractures were measured in outcrops with well exposed bedding surfaces, mostly in horizontal intertidal terraces at low tide. This minimizes any possibility of orientational sample bias that can be present in vertical exposures, and makes the relative abundance of the fracture sets statistically more valid.

In both areas, a pair of nearly orthogonal fracture sets dominates the population, but additional subsets are readily apparent. In the Black Hills area (fig. 4.2a), the most abundant set strikes east-northeast and the next most common fractures strike north-northwest. These correspond to the expected P-shear and R-shear orientations (e.g., Bartlett and others, 1981) related to the east-west trending dextral transpressive boundaries of the Black Hills Uplift. The fracture data collected near the David River Zone on Herendeen Bay (fig. 4.2b) are interpreted differently. Here, the strongest set strikes north-northeast, perpendicular to the trace of the poorly exposed fault that thrusts the Naknek Formation over the Bear Lake Formation. This population most likely consists of extensional joints related to this thrust shortening. Additional subsets striking west-northwest and east-northeast are probably early-formed shear joint sets akin to the steep north- and south-dipping joints and faults described from the Bear Lake Formation in the following section.

In summary, there are significant orientational and probably genetic differences between fracture populations in the Black Hills and Herendeen Bay areas. These differences are taken as evidence of variations in the structural style and stress-strain history along the length of the David River Zone that forms the southern boundary of the Bristol Bay basin in the southwestern part of the lease sale area. While not conclusive by themselves, the fracture data suggest the ratio of strike-slip to normal convergence may increase westward along the David River Zone.

Folding and Faulting of the Bear Lake Formation, Coal Point Area, Herendeen Bay

The Bear Lake Formation on the western shore of Herendeen Bay (fig. 4.1; Sections 9 and 15, T51S, R75W; also see the Coal Point measured section, sheet 1) was examined to document local patterns of faulting and folding, and investigate their relationship to the adjacent uplift to the south and the subsiding basin to the north. Bedding through most of the section strikes northwest, and dips gently to moderately to the southwest, except where reversed by local folding.

The transition from compressional uplift to extensional subsidence near Coal Point is described in figure 4.3. To the south, a north-vergent asymmetric anticline is present in the hangingwall of a north-northwest-striking, southwest-dipping reverse fault that runs up the vegetated gully from the beach. Beds at sea level in the footwall roll over to steep southern dip, suggesting that the reverse fault formed by forelimb breakthrough, parallel to the axial plane of the tight syncline. No fault striae are exposed, and none of the beds can be correlated across the fault, so neither the amount nor true vector of slip can be determined. The reverse fault strikes sub perpendicular to the north-northeast-trending vertical extension joint set observed in the nearby Naknek outcrops (fig. 4.2b), suggesting these structures are genetically linked.

Approximately $30 \mathrm{~m}$ north of the reverse fault is the first of an array of normal faults. The largest of these faults is downthrown to the north, with a displacement of approximately $5 \mathrm{~m}$. Of the five normal faults with approximately measured strike and dip, the south-dipping faults strike west-northwest (sub parallel to the reverse 
fault), and the north-dipping faults strike east-northeast to northeast (fig. 4.3c). These two fault orientations correspond closely to the strike of fracture subsets measured in the Naknek Formation (fig. 4.2b). Both the north- and south-dipping normal faults appear to have evolved from conjugate shear joints traced in the photosketch of Figure 4.3a. These shear joints are oriented symmetrically with respect to bedding, suggesting they formed prior to southward tilting of the section, and were subsequently exploited to accommodate compression in the uplift to the south and extension in the subsiding basin to the north.

From a petroleum exploration perspective, it is tantalizing to see these closely juxtaposed compressional and extensional domains. These relationships suggest the possibility of a compressional overhang at the southern margin of a reservoir-prone extensional basin, or at a minimum, an elevated likelihood of encountering anticlinal closures or fault-buttress traps.

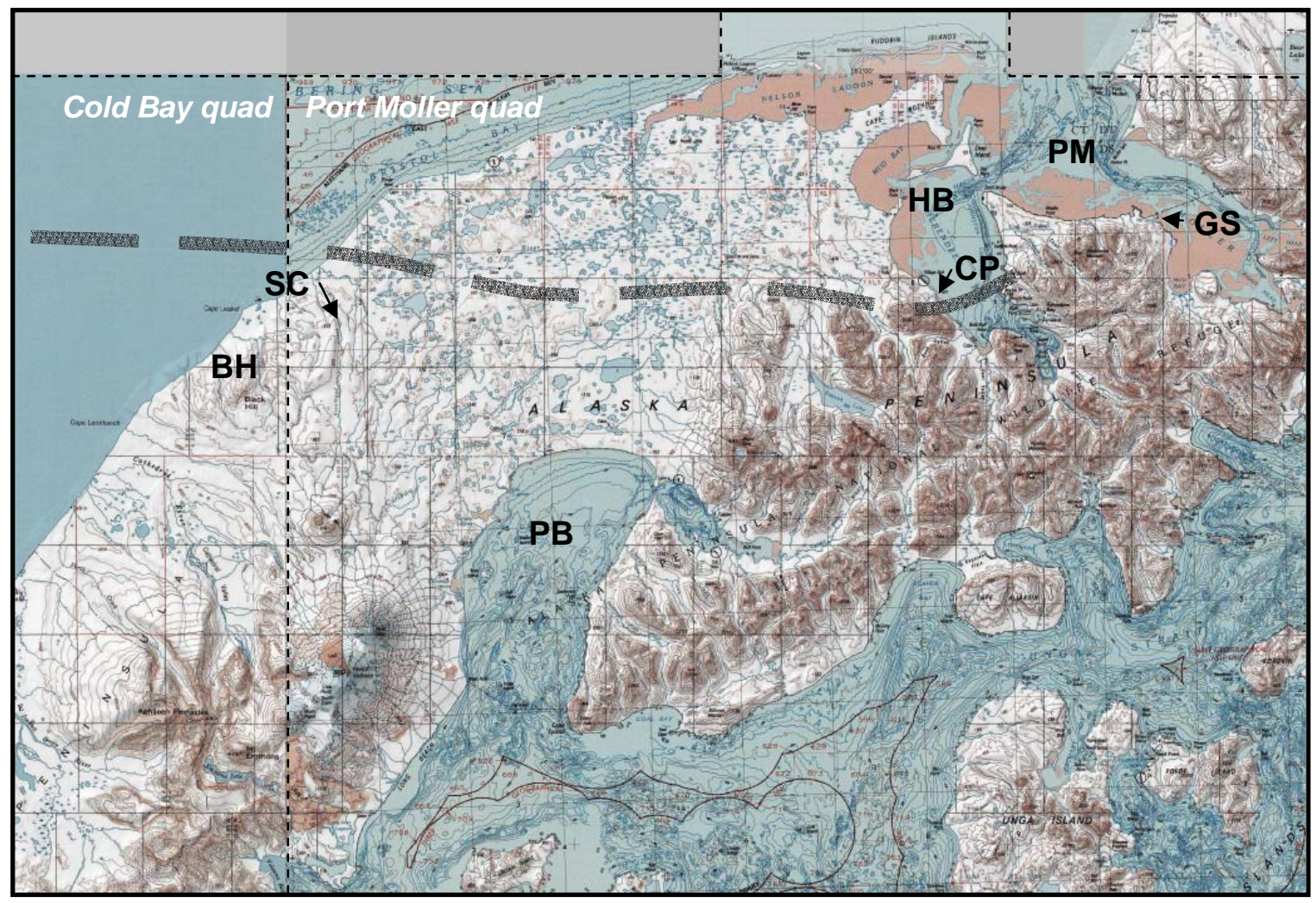

Figure 4.1. Location map of southwestern Alaska Peninsula, reduced from 1:250,000 scale USGS topographic maps. Lacking more specific information, the David River Zone is represented schematically as a dashed line between uplands with Mesozoic exposures on the south and mostly covered lowlands with occasional Miocene exposures on the north. In actuality, we envision it as a broader belt of structural relief distributed across multiple faults and dip panels. Locations referred to in this section of the text include Black Hills (BH), Steelhead Creek (SC), Coal Point (CP), and Herendeen Bay (HB). Also marked are Pavlof Bay (PB), Port Moller (PM), and prolific natural gas seep (GS) at Port Moller Hot Spring. Note USGS mapping errors in Cold Bay quadrangle, resulting in misplaced shoreline and other positional errors in the Black Hills area. 

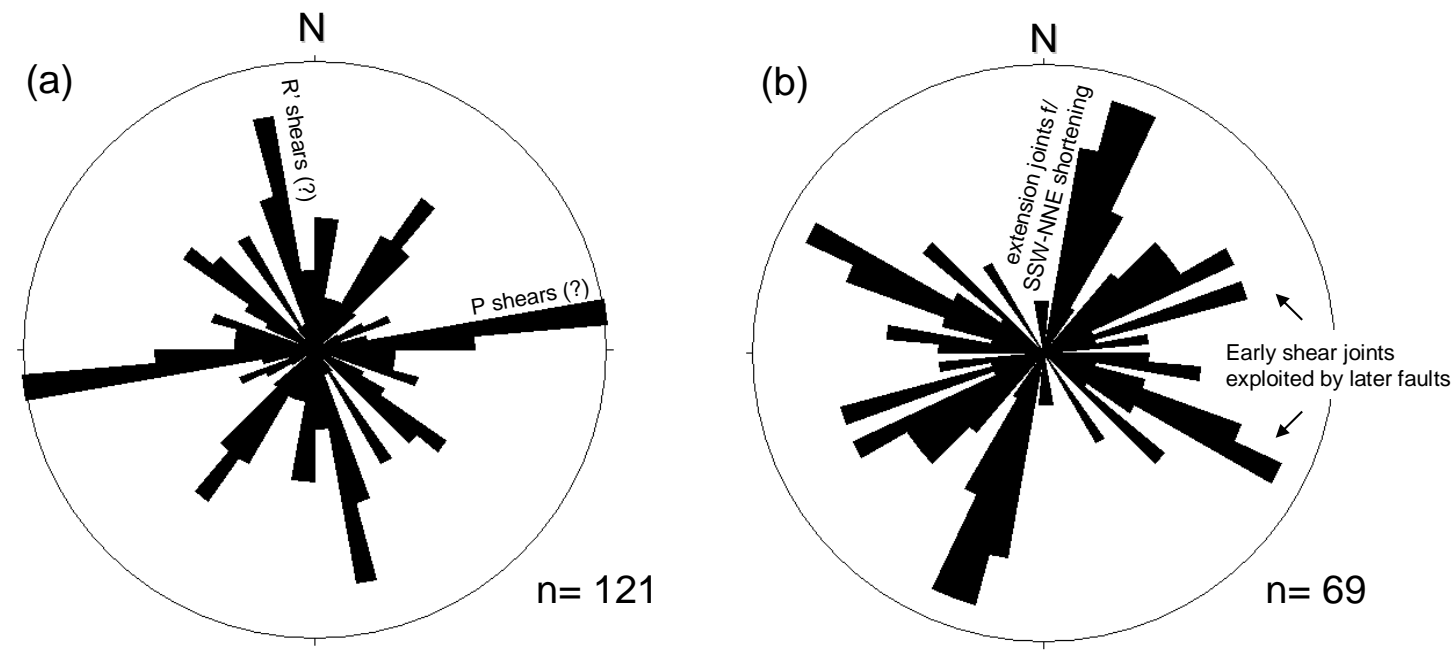

Figure 4.2. Rose diagrams of strike orientation of steeply dipping to vertical fractures in Jurassic Naknek Formation in the southwestern portion of the lease sale area in (a) the Black Hills-Cathedral River area and (b) western Herendeen Bay. Both locations have a pair of nearly orthogonal dominant fracture sets and additional subpopulations with a range of orientations. In the Black Hills area, the dominant ENEWSW set may represent the P-shear orientation of the dextral transpressive trend of the Black Hills Uplift, and the NNW-SSE set may represent the R' orientation. In the Herendeen Bay area, the NNESSW set is interpreted as extension joints formed during shortening that thrusted Naknek Formation northward over Miocene Bear Lake Formation. The other fracture sets there may be shear joints genetically related to the post-Bear Lake normal and reverse faults exposed in coastal outcrops further north (fig. 4.3). Outer circle represents $9 \%$ of population in (a) and $8 \%$ in (b). Plots generated using StereoWin 1.2, courtesy of R.W. Allmendinger. 


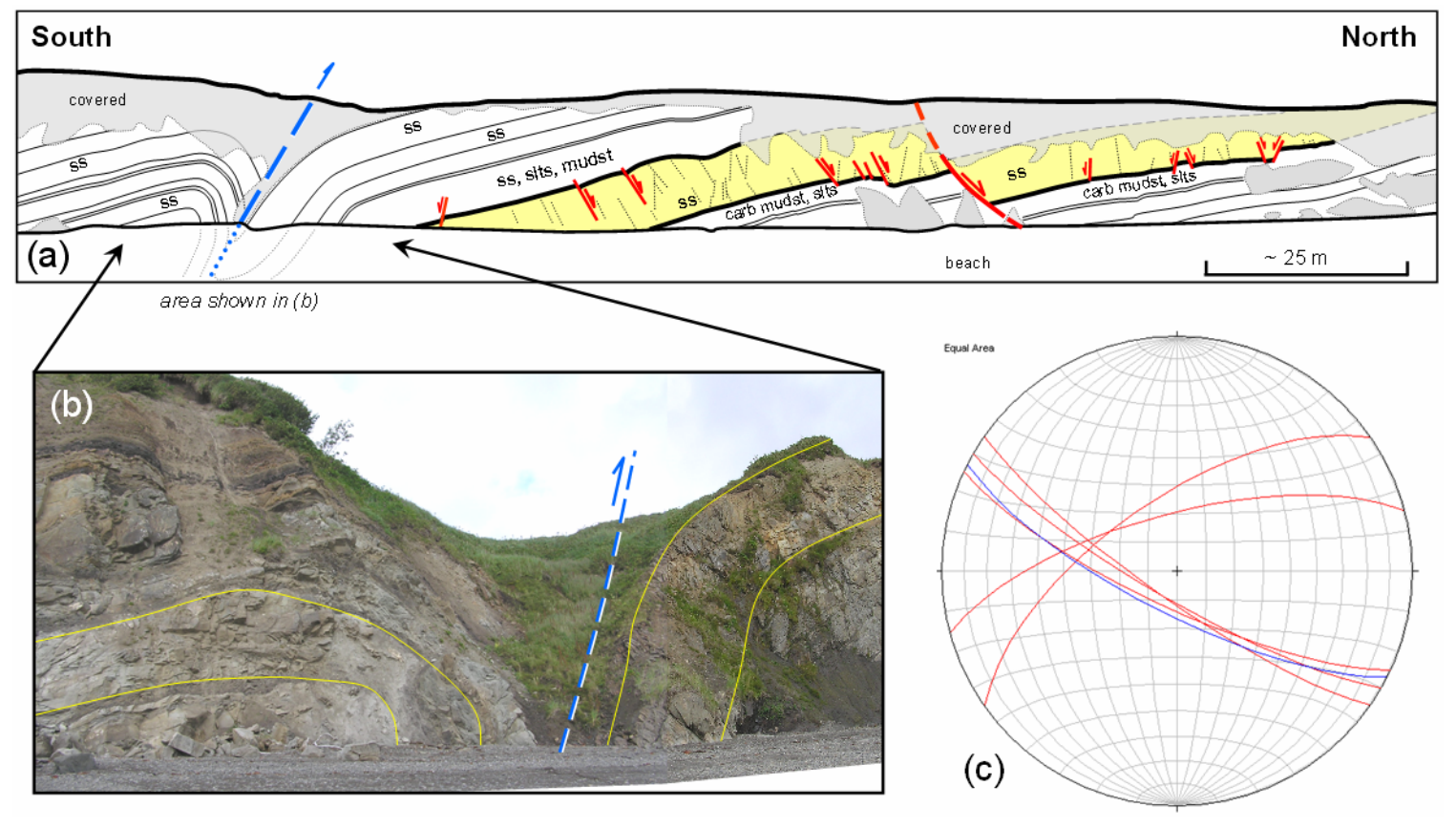

Figure 4.3. Structure in Bear Lake Formation, western shore of Herendeen Bay south of Coal Point. (a) Photosketch view to west showing array of minor normal faults (red) and shear joints (dotted) dipping both north and south in competent sandstone unit. Displacements accommodate mainly down-to-NW subsidence of the Bristol Bay basin in post-Miocene time. (b) North-vergent asymmetric anticline and steep reverse fault (blue) shown in photosketch; beds appear somewhat distorted in this perspective. Fold located at $55.784^{\circ} \mathrm{N}, 160.872^{\circ} \mathrm{W}$, Section $9, \mathrm{~T} 51 \mathrm{~S}, \mathrm{R} 75 \mathrm{~W}$. (c) Stereoplot of normal faults (red) and reverse fault (blue) from Coal Point outcrops. The reverse fault is nearly perpendicular to and probably genetically related to the main NNE-striking extension joint set in the Naknek Formation approximately $3 \mathrm{~km}$ farther south along the shoreline exposures, and both the normal and reverse faults strike approximately parallel to other Naknek Formation joint sets (compare to rose diagram Fig. 4.2b). StereoWin 1.2 software courtesy of R.W. Allmendinger. 


\section{Section V. Outcrop Organic Geochemistry and Coal Evaluation}

by R.R. Reifenstuhl

\section{Introduction}

As part of the overall evaluation of the hydrocarbon potential of the Bristol Bay Basin, a comprehensive suite of samples were collected to assess the source rock potential of targeted stratigraphic intervals. Preliminary, and in some cases, incomplete results of 34 total organic carbon and pyrolysis analyses were available for inclusion in this report (table 5.1). These data represent a small fraction of the total geochemical sampling program; the remaining organic geochemical data will be released as they become available.

Thirteen samples were collected from coastal exposures of the Mesozoic source rock units from the Chignik subterrane (Wilson and others, 1999) at Puale Bay. Eight samples were analyzed from the Middle Jurassic Kialagvik Formation and five from the Upper Triassic Kamishak Formation. The subsurface distribution of these Mesozoic rock units beneath the lease sale area is uncertain, but they may constitute significant important source rocks for both oil and gas. We infer their presence along at least the margin of the Bristol Bay basin south and west of Port Moller, based on their stratigraphic relationship with the Upper Jurassic Naknek Formation, which crops out south and west of Coal Point and the Staniukovich Mountain area (Wilson and others, 1999). This relationship is confirmed at the Cathedral River 1 well, which clearly documents the presence of the Kialagvik Formation below outcrops of Upper Jurassic Naknek Formation in the western end of the lease sale area, though opinions differ over whether it reached the Kamishak Formation (public well file reports by both Amoco [operator] and Shell; Detterman, 1990; Mickey and others, 2005).

In the Port Moller area, 21 samples were analyzed. Four are from the Coal Valley Member of the Chignik Formation (Herendeen Bay area), four are from the Paleocene to Eocene Tolstoi Formation (Pavlof Bay), and 13 are from the Miocene Bear Lake Formation (Bear Lake area; Herendeen Bay). All samples were analyzed by Baseline Resolution, Inc., Shenandoah, Texas.

\section{Results}

Samples from the Kialagvik Formation range in total organic carbon (TOC) from 0.71 to 3.51 percent (table 5.1 and fig. 5.1). The Kialagvik sample with anomalous TOC of 48.31 percent included carbonized woody debris. Comparison of the hydrogen and oxygen indices indicate the Kialagvik samples include both type I and type II kerogen (fig. 5.2).

Samples from the Kamishak Formation (fig. 5.3) range from 0.04 to 0.15 percent TOC. In the Van Krevelen diagram (hydrogen index vs. oxygen index plot) of figure 5.2, the five Kamishak Formation limestone samples fall in the range of mixed type II and type III kerogens. This is in contrast to our 2004 field season outcrop samples of the Kamishak Formation, which plotted in the type I and type II kerogen fields, with hydrogen indices of 475 and 600 (Finzel and others, 2005a). Additionally, three previous samples of the Kialagvik Formation plotted in the type III and type VI kerogen fields, with hydrogen indices of approximately 75 (Finzel and others, 2005a).

Pyrolysis data from two samples of the Tolstoi Formation indicate hydrogen index values of 253 and 7 (fig. 5.1). Data from the Bear Lake Formation samples are also shown in table 5.1. Of particular note are the abnormally elevated Tmax values for samples 05EF118 and 05EF119. These samples were collected adjacent to the Alaska Peninsula volcanic edifice and likely reflect post-depositional thermal alteration. More complete geochemical analyses will be available soon for the Tolstoi, Stepovak, and Bear Lake formations.

Proximate and ultimate analyses were performed on 12 coal samples (tables 5.2 and 5.3). Analyses were conducted by Geochemical Testing, Somerset, Pennsylvania. Coal samples were collected by digging with a pickaxe into the coal horizon a minimum of $40 \mathrm{~cm}$, and locally as deep as $80 \mathrm{~cm}$ (fig. 5.4). A chip sample was collected along the thickness of the seam and sealed in plastic bags. Most of the coal sampled contained substantial inorganic material (ash and sulfur; table 5.2).

Analytical results indicate apparent rank of coals in the Bear Lake Formation varies from Lignite A to High-volatile Bituminous A (tables 5.2 and 5.3). Samples from the Coal Valley Member of the Chignik Formation are High-volatile Bituminous C. Ten coal sample analyses from the Bear Lake and Chignik formations have not been returned from the laboratory at the writing of this report, but will be released when they become available. 


\begin{tabular}{|c|c|c|c|c|c|c|c|c|c|c|c|c|}
\hline Sample & Formation & Latitude & Longitude & $\begin{array}{l}\text { TOC } \\
\text { Wt. } \\
\% \\
\end{array}$ & $\begin{array}{c}\text { S1 } \\
\mathrm{mg} / \mathrm{g}\end{array}$ & $\begin{array}{c}\mathrm{S2} \\
\mathrm{mg} / \mathrm{g}\end{array}$ & $\begin{array}{c}\mathrm{S3} \\
\mathrm{mg} / \mathrm{g}\end{array}$ & Tmax & HI & Ol & $\begin{array}{l}\text { S1/ } \\
\text { TOC }\end{array}$ & PI \\
\hline $05 E F 100$ & Kialagvik & 57.73653 & 155.39818 & 0.71 & 0.13 & 1.15 & 0.55 & 425 & 162 & 77 & 18 & 0.10 \\
\hline $05 \mathrm{EF} 101$ & Kialagvik & 57.73612 & 155.39775 & 2.79 & 0.77 & 18.94 & 0.67 & 425 & 680 & 24 & 28 & 0.04 \\
\hline $05 \mathrm{EF} 102$ & Kialagvik & 57.73528 & 155.39732 & 1.22 & 0.18 & 4.44 & 0.60 & 428 & 364 & 49 & 15 & 0.04 \\
\hline $05 \mathrm{EF} 103$ & Kialagvik & 57.73480 & 155.39700 & 1.92 & 0.47 & 10.64 & 0.64 & 429 & 554 & 33 & 24 & 0.04 \\
\hline 05RR208 & Kialagvik & 57.73674 & 155.40101 & 3.51 & 0.89 & 22.12 & 0.67 & 423 & 630 & 19 & 25 & 0.04 \\
\hline 05RR209A & Kialagvik & 57.73786 & 155.40276 & 0.81 & 0.13 & 1.94 & 0.49 & 425 & 240 & 60 & 16 & 0.06 \\
\hline 05RR210A & Kialagvik & 57.73909 & 155.40446 & 1.46 & 0.22 & 4.56 & 0.38 & 424 & 312 & 26 & 15 & 0.05 \\
\hline 05RR210B & Kialagvik & 57.73909 & 155.40446 & 48.13 & 3.22 & 67.55 & 3.96 & 417 & 140 & 8 & 7 & 0.05 \\
\hline 05RR211A & Kamishak & 57.71422 & 155.36311 & 1.01 & 0.15 & 2.39 & 0.72 & 428 & 237 & 71 & 15 & 0.06 \\
\hline 05RR212A & Kamishak & 57.71674 & 155.36099 & 0.29 & 0.07 & 0.35 & 0.55 & 424 & 121 & 190 & 23 & 0.16 \\
\hline 05RR213A & Kamishak & 57.71677 & 155.36170 & 0.75 & 0.14 & 1.68 & 0.51 & 426 & 224 & 68 & 19 & 0.08 \\
\hline $05 E F 104$ & Kamishak & 51.71673 & 155.36079 & 0.04 & 0.02 & 0.04 & 0.26 & 458 & 100 & 650 & 50 & 0.34 \\
\hline $05 \mathrm{EF} 105$ & Kamishak & 57.71724 & 155.36040 & 0.53 & 0.08 & 0.71 & 0.35 & 429 & 134 & 66 & 15 & 0.10 \\
\hline $05 \mathrm{EF} 112$ & Chignik & 55.80863 & 160.75282 & & 1.97 & 155.78 & 3.48 & 413 & & & & 0.01 \\
\hline $05 \mathrm{EF} 118$ & Bear Lake & 55.99686 & 159.95311 & & 0.03 & 0.42 & 0.61 & 549 & & & & 0.07 \\
\hline $05 E F 119$ & Bear Lake & 55.99892 & 159.95325 & & 0.07 & 2.01 & 0.80 & 552 & & & & 0.03 \\
\hline $05 \mathrm{KC} 135 \mathrm{~B}$ & Tolstoi & 55.51673 & 161.43857 & 1.35 & 0.02 & 0.09 & 0.38 & 534 & 7 & 28 & 1 & 0.18 \\
\hline 05RR227C & Bear Lake & 56.00080 & 160.08804 & 0.05 & & & & & & & & \\
\hline 05RR231A & Chignik & 55.76619 & 161.15161 & 32.08 & & & & & & & & \\
\hline 05RR235C & Tolstoi & 55.50895 & 161.45127 & 1.12 & & & & & & & & \\
\hline 05RR236B & Tolstoi & 55.51119 & 161.44780 & 8.87 & 1.86 & 22.47 & 0.69 & 444 & 253 & 8 & 21 & 0.08 \\
\hline 05RR238A & Tolstoi & 55.51119 & 161.44780 & & 0.09 & 0.82 & 0.5 & 494 & & & & 0.10 \\
\hline $05 \mathrm{KC102}$ & Bear Lake & 56.05784 & 159.90356 & 52.9 & 7.23 & 99.26 & 23.45 & 395 & 188 & 44 & 14 & 0.07 \\
\hline $05 \mathrm{KC} 107$ & Bear Lake & 55.78481 & 160.87151 & 67.41 & 0.98 & 205.9 & 2.97 & 420 & 305 & 4 & 1 & 0.00 \\
\hline $05 \mathrm{KC108}$ & Bear Lake & 55.78359 & 160.87131 & 56.03 & 0.63 & 146.3 & 3.75 & 423 & 261 & 7 & 1 & 0.00 \\
\hline $05 \mathrm{KC1} 109$ & Bear Lake & 55.78338 & 160.87129 & 76.97 & 4.07 & 245.9 & 4.12 & 431 & 319 & 5 & 5 & 0.02 \\
\hline $05 \mathrm{KC} 110$ & Bear Lake & 55.78241 & 160.87091 & 79 & 1.33 & 238.2 & 3.53 & 429 & 302 & 4 & 2 & 0.01 \\
\hline 05KC112A & Chignik & 55.80713 & 160.75028 & 73.68 & 0.19 & 129.4 & 4.96 & 423 & 176 & 7 & 0 & 0.00 \\
\hline 05KC112B & Chignik & 55.80713 & 160.75028 & 69.27 & 0.26 & 165 & 4.57 & 419 & 238 & 7 & 0 & 0.00 \\
\hline $05 \mathrm{KC} 114$ & Bear Lake & 55.99046 & 60.00075 & 11.58 & 0.65 & 12.35 & 2.96 & 436 & 107 & 26 & 6 & 0.05 \\
\hline $05 \mathrm{KCl15}$ & Bear Lake & 55.99055 & 160.00096 & 61.45 & 3.11 & 112 & 7.05 & 434 & 182 & 11 & 5 & 0.03 \\
\hline $05 \mathrm{KCl1} 16$ & Bear Lake & 55.99086 & 160.00226 & 67.88 & 6.39 & 197.8 & 6.5 & 443 & 291 & 10 & 9 & 0.03 \\
\hline $05 \mathrm{KC} 118$ & Bear Lake & 55.99129 & 160.00340 & 61.8 & 1.99 & 83.29 & 11.12 & 435 & 135 & 18 & 3 & 0.02 \\
\hline $05 \mathrm{KC} 122$ & Bear Lake & 55.99315 & 160.00581 & 62.09 & 2.85 & 153.1 & 12.43 & 424 & 247 & 20 & 5 & 0.02 \\
\hline
\end{tabular}

Table 5.1. Results of total organic carbon and pyrolysis analyses. Data for coal samples shown in bold font. 


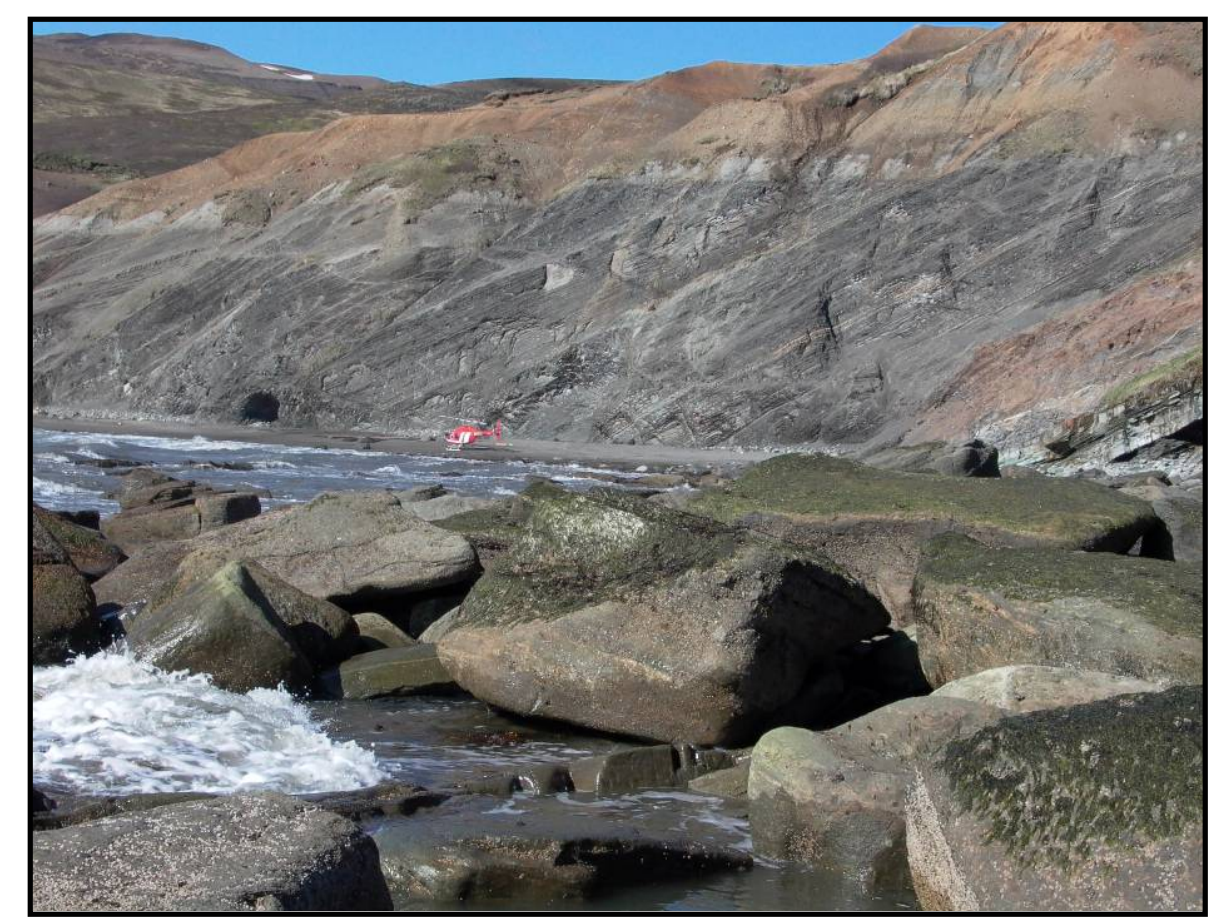

Figure 5.1. Middle Jurassic Kialagvik Formation, Puale Bay.

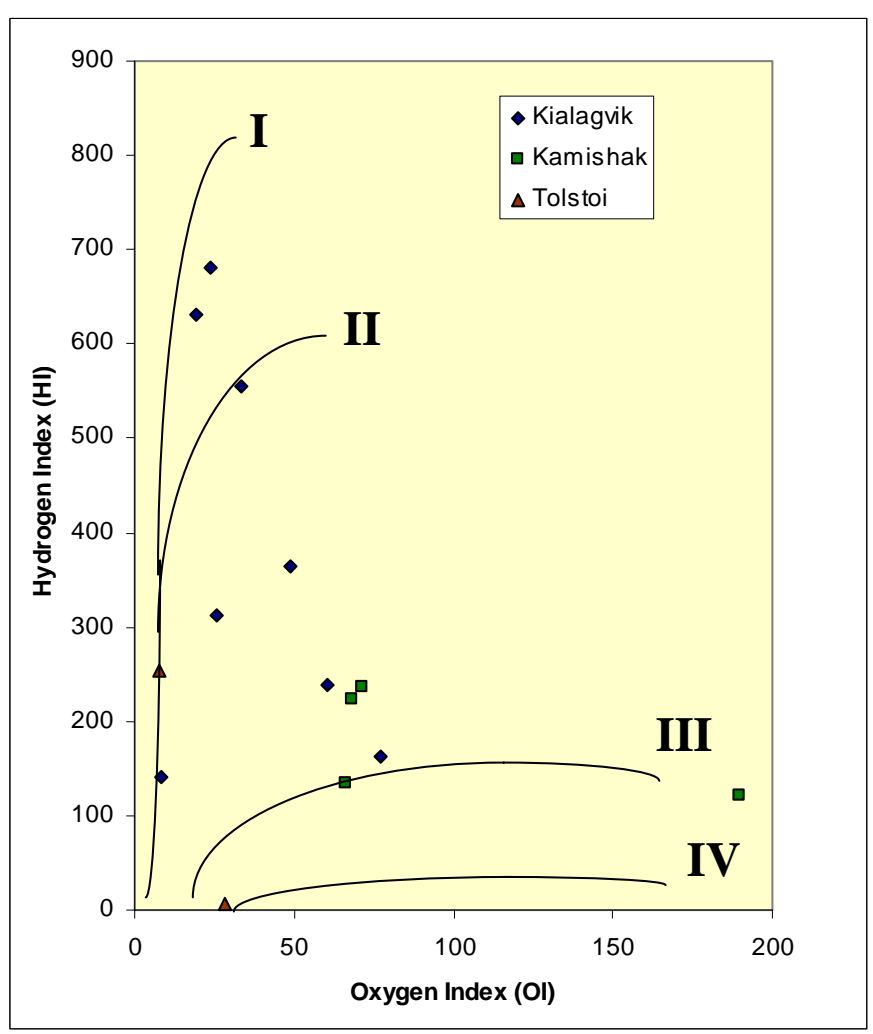

Figure 5.2. Kerogen type determination from TOC and Rock-Eval pyrolysis data. Types I and II will generate oil, type II gas, and type IV little or no hydrocarbons. 


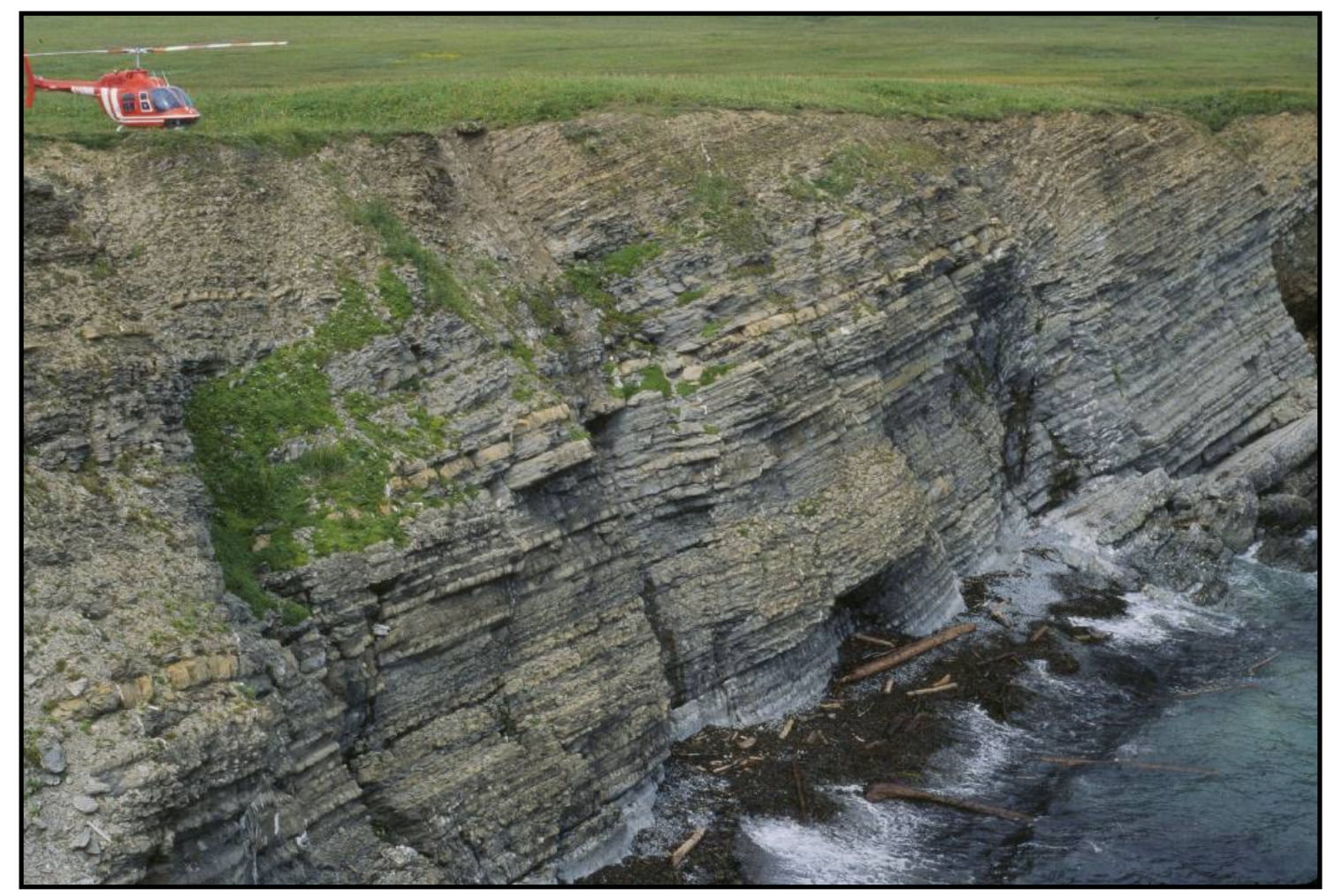

Figure 5.3. Upper Triassic Kamishak Formation limestone, Puale Bay. Cliffs are about 20 m high. 


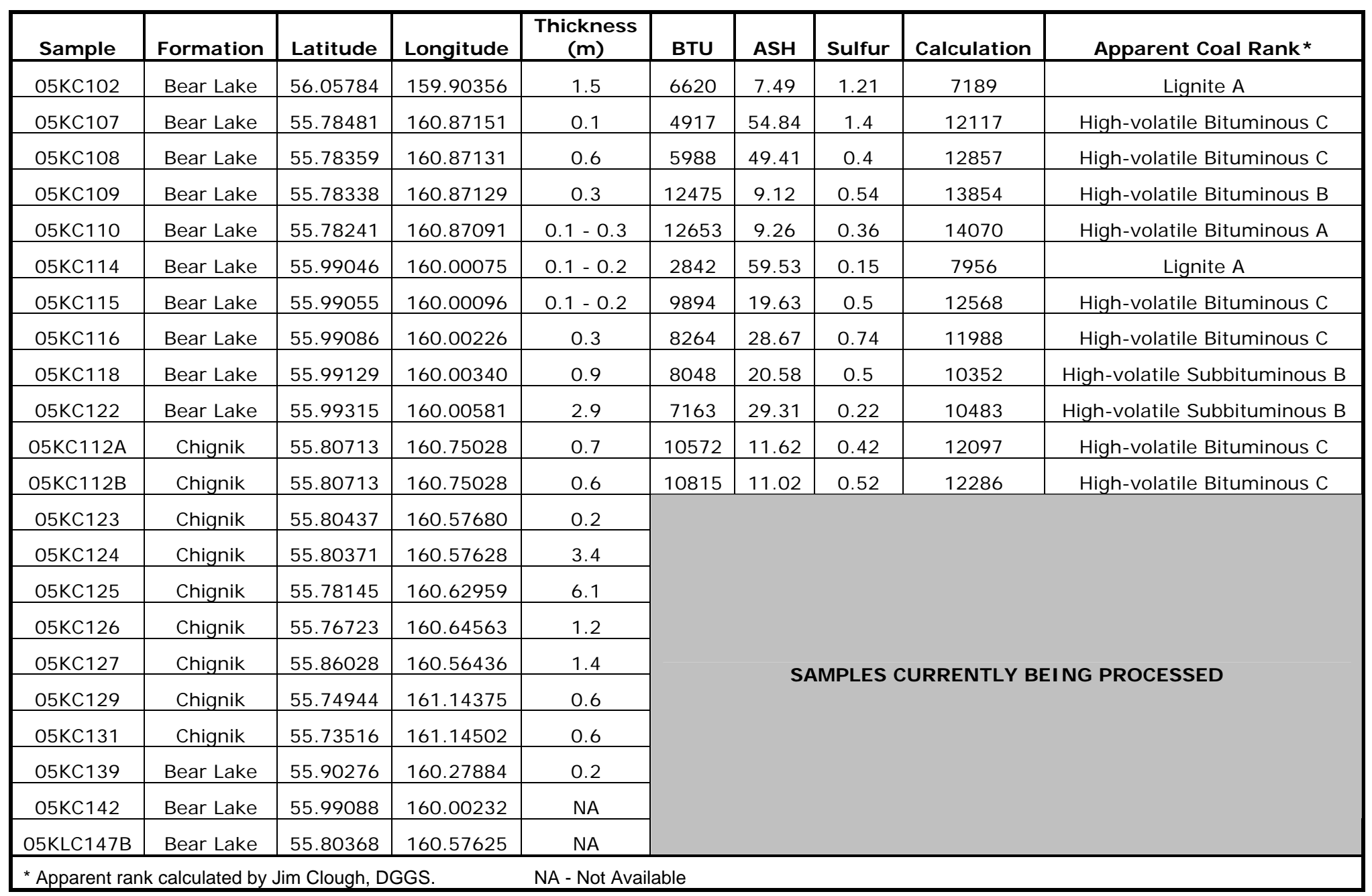

Table 5.2. Proximate and ultimate analytical results, and apparent coal ranking, for samples collected during the 2005 field season. 


\begin{tabular}{|c|c|}
\hline \multicolumn{2}{|c|}{ Apparent Rank Table } \\
\hline APPARENT RANK & BTU \\
\hline Lignite B & $<6300$ \\
\hline Lignite A & $<$ or $=6300<8300$ \\
\hline High-volatile Subbituminous C & $<$ or $=8300<9500$ \\
\hline High-volatile Subbituminous B & $<$ or $=9500<10500$ \\
\hline High-volatile Subbituminous A & $<$ or $=10500<11500$ \\
\hline High-volatile Bituminous C & $<$ or $=11500<13000$ \\
\hline High-volatile Bituminous B & $<$ or $=13000<14000$ \\
\hline High-volatile Bituminous A & $>14000$ \\
\hline & FI XED CARBON \\
\hline Medium-volatile Bituminous & $69 \%-78 \%$ \\
\hline Low-volatile Bituminous & $78 \%-86 \%$ \\
\hline SemiAnthracite & $86 \%-92 \%$ \\
\hline Anthracite & $92 \%-98 \%$ \\
\hline MetaAnthracite & $>98 \%$ \\
\hline
\end{tabular}

Table 5.3. Key to apparent coal ranks from table 5.2.

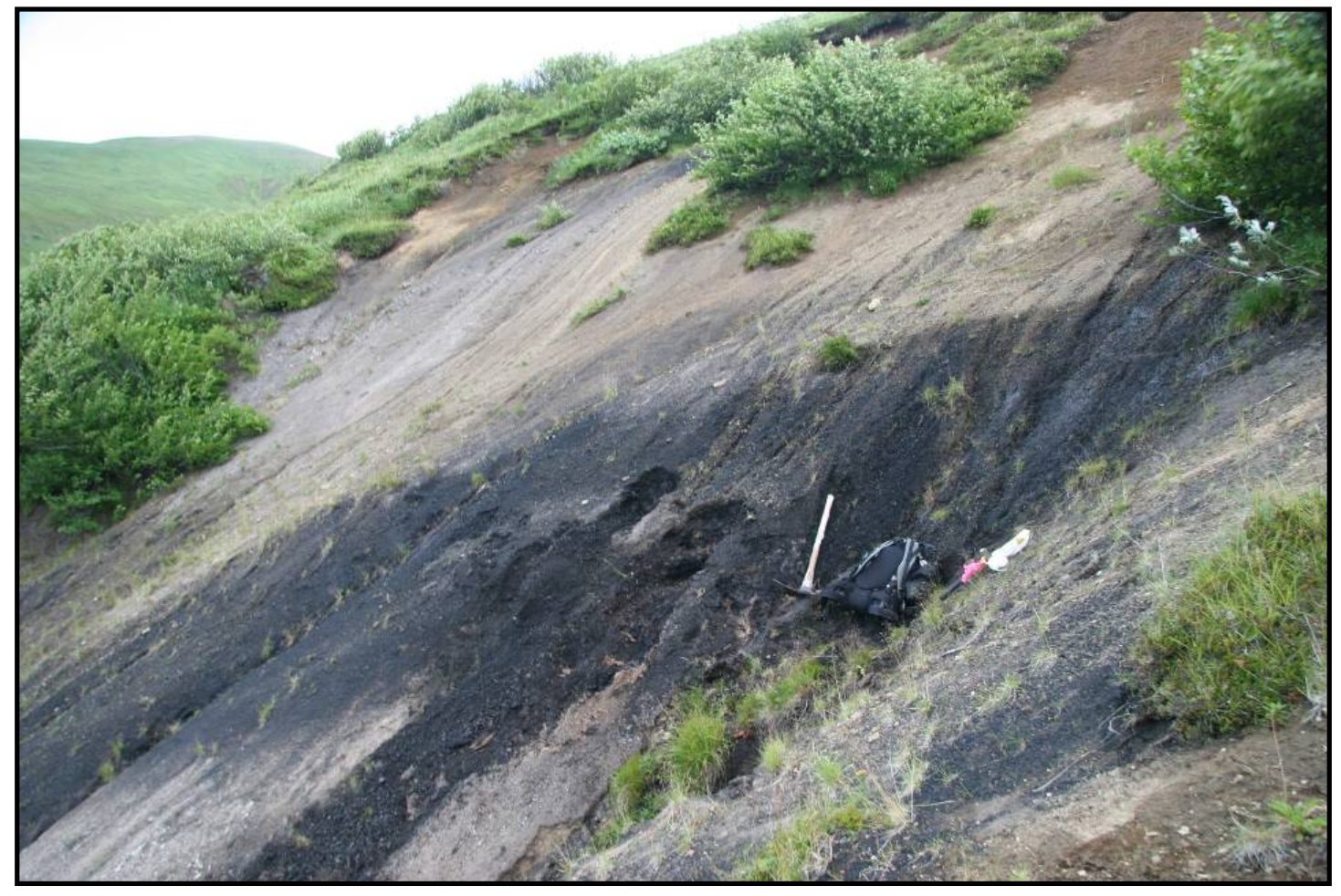

Figure 5.4. One-meter-thick coal seam in the Coal Valley Member of the Chignik Formation. Actual thickness of coal seam is less than it appears on weathered slope. Pickaxe $1 \mathrm{~m}$ long for scale. 


\section{Section VI. Isotope Geochemistry, Composition, and Origin of Natural Gas Seep \\ in Herendeen Formation Hot Springs, Port Moller Area \\ by P.L. Decker and R.R. Reifenstuhl}

\section{Introduction}

Project field personnel in 2005 resampled the prolific gas seep associated with the hot spring issuing from the Lower Cretaceous Herendeen Formation on the peninsula between Port Moller and Herendeen Bay (location $55.86222^{\circ} \mathrm{N}, 160.49309^{\circ} \mathrm{W}$; fig. 4.1). The primary goal of this resampling was to obtain carbon and deuterium isotope data to definitively determine whether the gas is biogenic or thermogenic in origin, as well as to verify its previously determined composition. The same gas seep was sampled during the 2004 field season, and the very high methane content determined by compositional analysis (99.1 percent; Reifenstuhl and others, 2005; table 2) was assumed to reflect a biogenic origin (Reifenstuhl and Finzel, 2005). However, this preliminary interpretation did not consider the possibility that the gas was simply a dry thermogenic product, which can only be ruled out through isotopic analysis. The seep is of particular interest in that it is on the axis of the northeast-plunging nose of the anticline mapped in the Staniukovich Mountain area (Burk, 1965; Wilson and others, 1999).

\section{Sampling Methodology}

The gas bubbles vigorously at the source of the hot spring in an approximately 1.5-m-wide by 2-m-long pool of clear water approximately $0.5 \mathrm{~m}$ deep that rises through thin surficial cover overlying highly fractured sandstones of the Herendeen Formation. The temperature of the spring is reported by Waring, (1965) as $160^{\circ} \mathrm{F}\left(71^{\circ} \mathrm{C}\right)$, and protective rubber gloves were useful in collecting the samples. Three samples were collected in $250 \mathrm{ml}$ I-CHEM amber glass bottles by first submerging the bottle underwater, filling it completely with water, then inverting the bottle over the rising gas bubbles (with the mouth still underwater), allowing the rising gas bubbles to displace most of the water from the bottle, then replacing the threaded cap underwater in the same position. Samples were maintained in an inverted orientation until shipping to the laboratory, to minimize any tendency of the gas to leak out or air to leak in across the sealed threads.

\section{Results and Discussion}

Results of analyses are presented in tables 6.1 and 6.2. In percentage terms, the three new samples are compositionally identical with each other and with the 2004 sample, confirming that the gas is 99.1 percent to 99.2 percent methane, and 0.8 percent to 0.9 percent wet gas (ethane-propane-butane; table 6.1). The more revealing data are the carbon and deuterium isotope values of the methane, ethane, and propane species (table 6.2), which appear from inspection to indicate that the gas is thermogenic, not biogenic as had been assumed previously. Run on two samples for quality assurance, the per mil isotope values vary between samples by less than 1 percent, suggesting the data are reliable. Figure 6.1 presents the values of $\mathrm{de}^{13} \mathrm{C}$ versus delD isotopes of the methane on a natural gas plot after Schoell (1983), where the data fall clearly within the realm of thermogenic petroleum-associated gas, far removed from the bacterial (biogenic) field. This plot, based only on the methane isotopes, suggests further that the natural gas percolating out of the Herendeen Formation may be associated more closely with condensate than with black oil, due either to kerogen type of the source rock or to the thermal maturity level. More in-depth interpretations of the data, including an estimated thermal maturity of the gas, will be released in future reports.

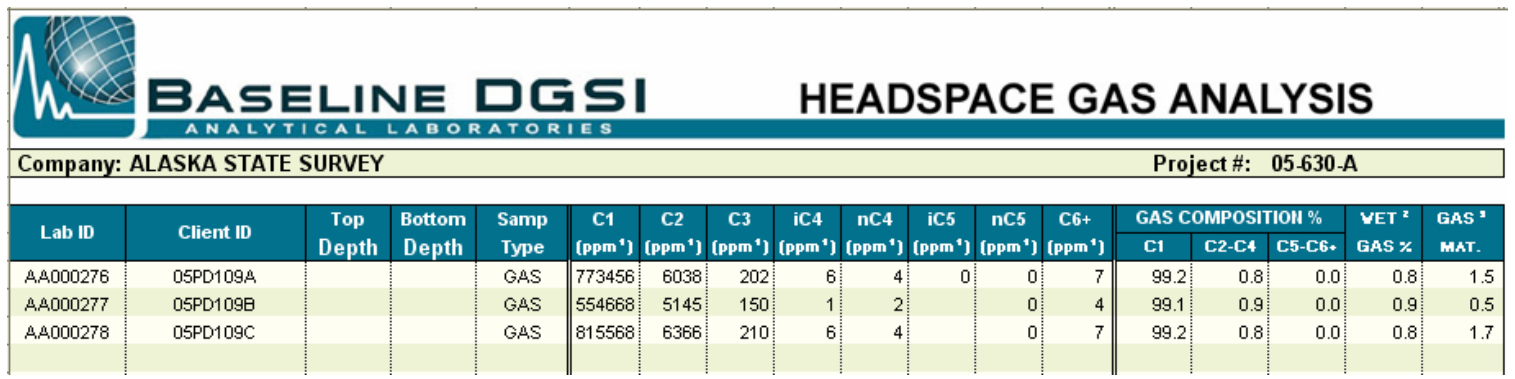

Table 6.1. Results of compositional analysis of three 2005 natural gas samples from gas seep in hot spring issuing from the Herendeen Formation, axis of Staniukovich Mountain anticline, Port Moller area. 


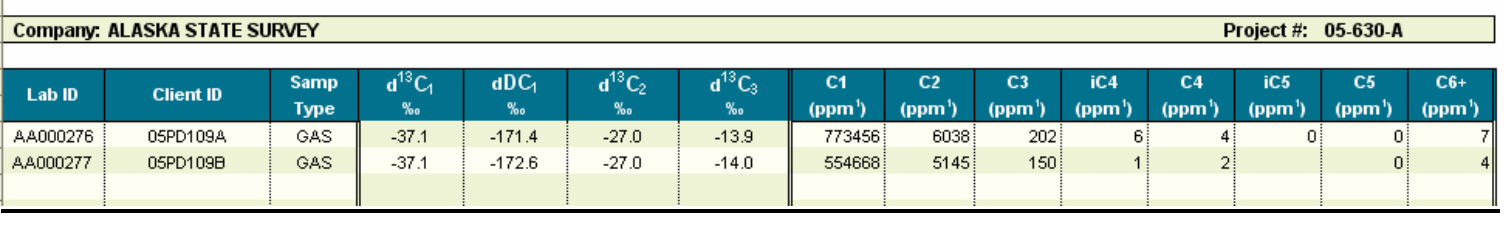

Table 6.2. Results of carbon and deuterium isotope analysis of two of the three 2005 natural gas samples from gas seep in hot spring issuing from the Herendeen Formation, axis of Staniukovich Mountain anticline, Port Moller area.

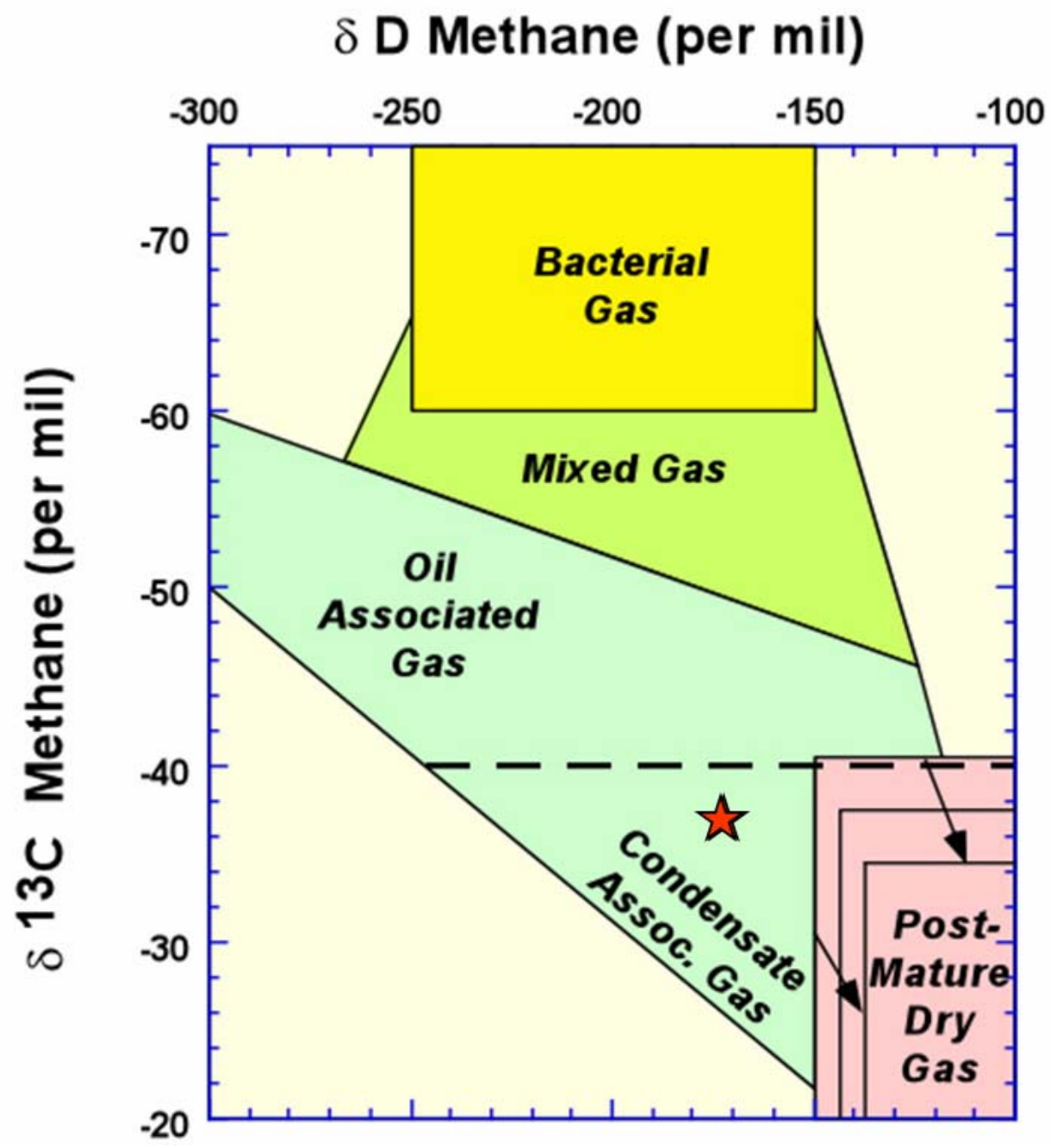

Figure 6.1. Plot of carbon vs deuterium isotopes of methane from two 2005 samples of the gas seep at the hot spring in fractured Herendeen Formation sandstone, Port Moller area. Both samples plot at essentially the same point (red stars) in the condensate-associated thermogenic field; they are not biogenic (bacterial) as had been previously assumed. Plot format after Schoell (1983). 


\section{Section VII. Investigation of Historically Reported Oil Seeps in the Greater Dillingham Area: \\ Fieldwork and Sample Analyses \\ by R.R. Reifenstuhl}

\section{Introduction}

Seven reported oil seep localities in the greater Dillingham area of Bristol Bay were visited and nine water or soil samples collected by R. Reifenstuhl and E. Finzel August 1-2, 2005. Seven sites were visited: Black Point, Nushagak River, Muklung River, Clark Point, Acorn Peak, Twin Hills, and Protection Point (fig. 7.1). The reported seeps included sites investigated by the U.S. Geological Survey (USGS) during the 1950s and 1960s (Miller and others, 1959; Miller, D.J., unpublished notes). The USGS was unable to prove the existence of any oil seep in the greater Dillingham area. In addition to the USGS sites, other potential hydrocarbon occurrences were recently identified by local resident George Shade, who provided detailed attributes, directions, and specific locations. Mr. Shade had compiled reports of potential oil seeps based his personal knowledge of the area and from individuals living in the greater Dillingham area. Some of these sites were identified based on a purplish-blue sheen, others for the persistent local winter thawing, and a few for unusual hydrologic patterns in the tidal zone.

\section{Methodology}

Samples were collected using $250 \mathrm{ml}$ I-CHEM amber glass bottles. An effort was made to collect the typical purplish-blue sheen on the water, and any other site material that indicated a potential primary oil seep or that might reflect secondary petroleum contamination. At all locations where a purplish-blue film was present, the water was stirred to qualitatively evaluate the physical properties of the substance.

\section{Results}

All seven localities had a purplish-blue sheen marking a thin film on standing water or on slowly moving water. This thin surface film completely fractured upon stirring the water-a behavior that is inconsistent with the presence of hydrocarbons. A film caused by petroleum will tend to seamlessly re-associate following a disturbance.

Material sampled was typically purplish-blue film and water, or light brownish-tan foam and water, or light brown loamy soil. All nine samples were sent within 48 hours to SGS laboratories, Anchorage, Alaska, for petroleum detection. All nine samples were reported to contain iron bacteria and were devoid of detectable hydrocarbons. The SGS analyst noted that iron bacteria commonly forms the purple-blue sheen on anoxic ponds and small streams in muskegs and low relief areas. Immediately after the SGS analyses, the remainder of each of the nine samples was sent to Baseline Resolutions, Inc., Shenandoah, Texas. The samples will be analyzed using a chlorine process that will definitively test for the presence of petroleum, raw or refined. Future reports will present the raw data from these samples, but these preliminary results suggest that none of the reported potential seeps are related to hydrocarbons.

\section{Acknowledgments}

Field operations and analyses for the 2005 field season were funded from multiple sources: A U.S. Department of Energy grant from the Arctic Energy Technology Development Laboratory at the University of Alaska Fairbanks to R. Reifenstuhl (program head) and Paul McCarthy (principal investigator, UAF); contributions from Bristol Bay Native Corporation; and DGGS and DOG operating budgets. Field work was carried out by the authors and Karen Clautice (DGGS). Helicopter-supported field operations benefited greatly from the expertise of pilot Tom Ratledge, Yukon Helicopters. The authors thank Marwan Wartes and Robert Swenson (DGGS) for substantive reviews. 


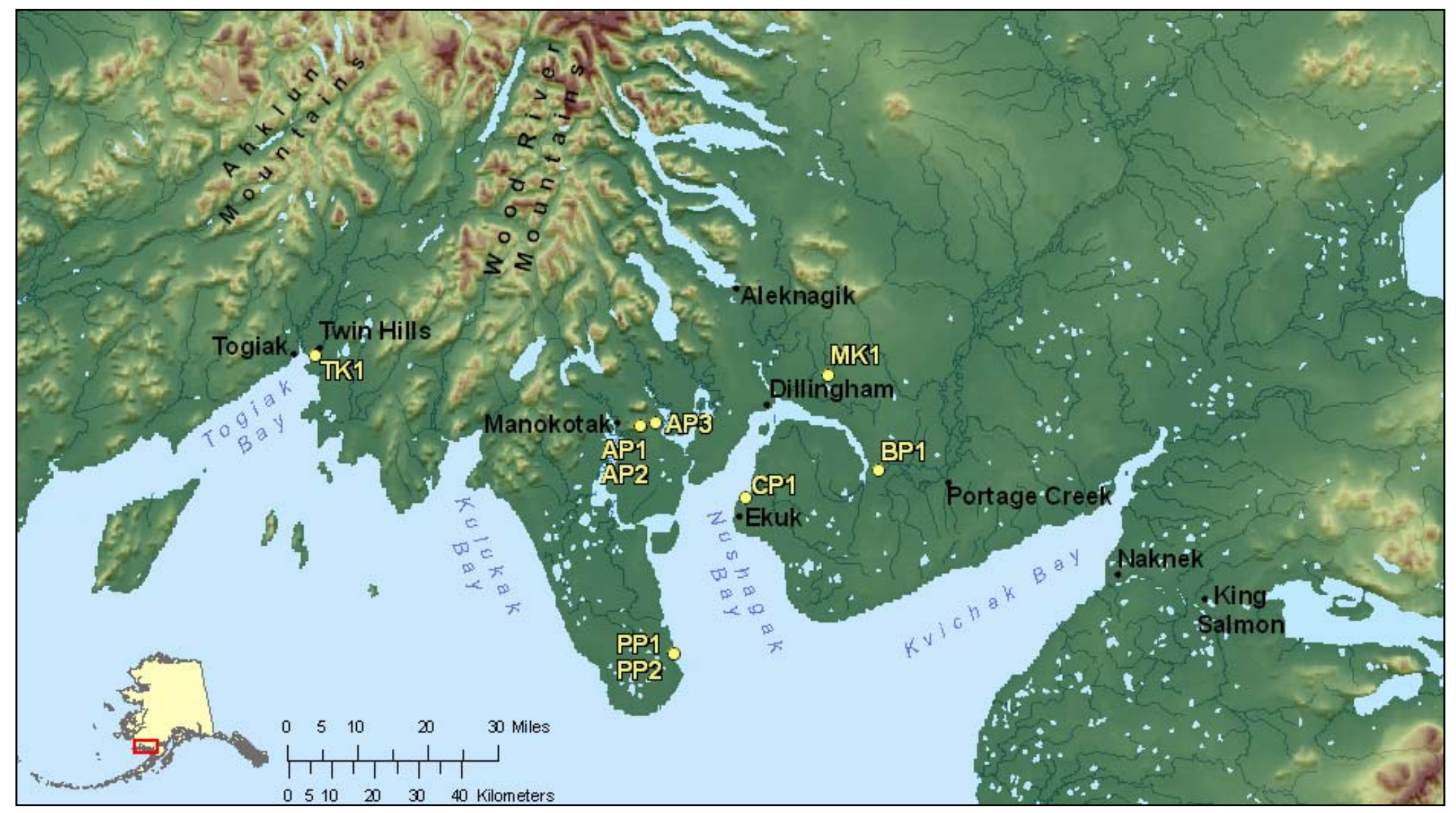

Figure 7.1. Location map of the reported oil seeps in the greater Dillingham area, Bristol Bay. Seven sites were visited and nine samples collected during this project. Dots with letters and number indicate sample location site. TK= Togiak, $A P=$ Acorn Peak, $P P=P r o t e c t i o n$ Point, $C P=$ Clark Point, $M K=$ Muklung River, and $B P=$ Black Point. 


\section{$\underline{\text { References Cited }}$}

Allison, R.C., and Addicott, W.O., 1976, The North Pacific Miocene record of Mytilus (Plicatomytilus), a new subgenus of Bivalvia: U.S. Geological Survey Professional Paper 962, 22 p., 3 plates.

Bartlett, W.L., Friedman, M., and Logan, J.M., 1981, Experimental folding and faulting of rocks under confining pressure, Part IX, Wrench faults in limestone layers: Tectonophysics, v. 79, p. 255-277.

Beikman, H.M., 1980, Geologic map of Alaska, U.S. Geological Survey, scale 1:2,500,000.

Blodgett, R.B., in prep, Observations on Mesozoic fossils and stratigraphy during field investigations of the northern Alaska Peninsula (Puale Bay, Wide Bay, and Lake Becharof Region) by the ADGGS/ADOG, May 24-June 4, 2004 (in preparation).

Burk, C.A., 1965, Geology of the Alaska Peninsula-island arc and continental margin: Geological Society of America Memoir 99, pts. 1-3, 250 p.

Detterman, R.L., 1978, Interpretation of depositional environments in the Chignik Formation, Alaska Peninsula, in Johnson, K.M., ed., The United States Geological Survey in Alaska_Accomplishments during 1977: U.S. Geological Survey Circular 772-B, p. B62-B63.

Detterman, R.L., 1990, Stratigraphic correlation and interpretation of exploratory wells, Alaska Peninsula: U.S. Geological Survey Open File Report 90-279, 51 p., 2 plates.

Detterman, R.L., Yount, M.E., and Case, J.E., 1981, Megafossil sample locality map, checklists, and stratigraphic sections of the Chignik and Sutwik Island quadrangles, Alaska: U.S. Geological Survey Miscellaneous Field Studies Map MF-1053-N, 2 sheets.

Detterman, R.L., Case, J.E., Miller, J.W., Wilson, F.H., and Yount, M.E., 1996, Stratigraphic framework of the Alaska Peninsula: Geologic Studies on the Alaska Peninsula, U.S. Geological Survey Bulletin 1969-A, 74 p.

Division of Oil \& Gas, 2004, Alaska Peninsula areawide oil and gas lease sale and Bristol Bay basin exploration license area, information and data compilation, 3 volume CD-ROM.

Division of Oil \& Gas, 2005, Regional gravity, aeromagnetic, and geologic maps of the Bristol Bay/Alaska Peninsula region, 1 volume mini-CD-ROM.

Fairchild, D.T., 1977, Paleoenvironments of the Chignik Formation, Alaska Peninsula: Fairbanks, University of Alaska, Master's thesis, $168 \mathrm{p}$.

Finzel, E.S., Reifenstuhl, R.R., Decker, P.L., and Ridgway, K.D., 2005a, Sedimentology, stratigraphy, and hydrocarbon reservoir-source rock potential, using surface and subsurface data, of Tertiary and Mesozoic strata, Bristol Bay Basin and Alaska Peninsula: Alaska Division of Geological \& Geophysical Surveys Preliminary Interpretive Report 2005-4, 67 p.

Finzel, E.S., Ridgway, K.D, Decker, P.L., and Reifenstuhl, R.R., 2005b, Reservoir characterization of the Bear Lake and Milky River Formations, Bristol Bay Basin, Alaska Peninsula: Geological Society of America Abstracts with Programs, v. 37, no. 4, p. 96.

Gladenkov, A.Y., 2003, Diatom biostratigraphy of the Neogene Milky River Formation, Alaska Peninsula, southwestern Alaska: Proceedings of the California Academy of Science, v. 54, no. 3, p. 1-8.

Helmold, K.P., and Brizzolara, D.W., 2005, Reservoir quality of Tertiary sandstones from Bristol Bay basin, Alaska Peninsula: Preliminary Report: Alaska Division of Oil \& Gas technical report, 32 p., http://www.dog.dnr.state.ak.us/oill.

Hite, David, 2004, Bristol Bay Native Corporation-Hydrocarbon potential of Native lands in the Bristol Bay area, southern Alaska: BBNC files, Data Set Index No. 774.

Jones, D.L., and Silberling, N.J., 1979, Mesozoic stratigraphy - the key to tectonic analysis of southern and central Alaska: U.S. Geological Survey Open-File Report 79-1200, 37 p.

Kirschner, C.L., 1988, Map showing sedimentary basins of onshore and continental shelf areas, Alaska, U.S. Geological Survey Miscellaneous Investigations Series I-1873, 1 sheet, scale 1:2,500,000.

MacNeil. F.S., Wolfe, J.A., Miller, D.J., and Hopkins, D.M., 1961, Correlation of Tertiary formations of Alaska: American Association of Petroleum Geologists Bulletin, v. 45, p. 1801-1809.

Mancini, E.A., Deeter, T.M., and Wingate, F.H., 1978, Upper Cretaceous arc-trench gap sedimentation on the Alaska Peninsula: Geology, v. 6, no. 7, p. 437-439. 
Marincovich, Louie, Jr., 1983, Molluscan paleontology, paleoecology, and North Pacific correlations of the Miocene Tachilni Formation, Alaska Peninsula, Alaska: Bulletins of American Paleontology, v. 84, no. 317, p. 59155, plates 12-23.

Marincovich, Louie, and Powell, C.L., II, 1989, Preliminary Tertiary molluscan biostratigraphy of the Alaska Peninsula, southwestern Alaska: U.S. Geological Survey Open-File Report 89-674, 2 sheets.

Marlow, M.S., Cooper, A.K., and Fisher, M.A., 1994, Geology of the eastern Bering Sea continental shelf, in Plafker, G., and Berg, H.C., eds., The Geology of Alaska: Boulder, Colorado, Geological Society of America, The Geology of North America, v. G-1, p. 271-284.

Meyer, J.F., Jr., Hansen, J.J., Brizzolara, D.W., Pritchard, M.E., Boggess, P.L., Beaty, C.J., Dirks, K.L., Gumpert, J.D., Bolin, K.A., Gibler, K.I., and Phillipson, E.M., 2004a, Bristol Bay region and Alaska Peninsula oil and gas programs: Alaska Department of Natural Resources, Division of Oil \& Gas, Alaska Peninsula Resource Series, plate 1 of 4, http://www.dog.dnr.state.ak.us/oil/.

Meyer, J.F., Jr., Hansen, J.J., Brizzolara, D.W., Pritchard, M.E., Boggess, P.L., Beaty, C.J., Dirks, K.L., Gumpert, J.D., Bolin, K.A., Gibler, K.I., and Phillipson, E.M., 2004b, Regional geology of the Bristol Bay region and Alaska Peninsula: Alaska Department of Natural Resources, Division of Oil \& Gas, Alaska Peninsula Resource Series, plate 2 of 4, http://www.dog.dnr.state.ak.us/oil/.

Meyer, J.F., Jr., Hansen, J.J., Brizzolara, D.W., Pritchard, M.E., Boggess, P.L., Beaty, C.J., Dirks, K.L., Gumpert, J.D., Bolin, K.A., Gibler, K.I., and Phillipson, E.M., 2004c, Oil and gas well data for the Alaska Peninsula and Bristol Bay region: Alaska Department of Natural Resources, Division of Oil \& Gas, Alaska Peninsula Resource Series, plate 3 of 4, http://www.dog.dnr.state.ak.us/oil/.

Meyer, J.F., Jr., Hansen, J.J., Brizzolara, D.W., Pritchard, M.E., Boggess, P.L., Beaty, C.J., Dirks, K.L., Gumpert, J.D., Bolin, K.A., Gibler, K.I., and Phillipson, E.M., 2004d, Seismic data availability for the Bristol Bay region and the Alaska Peninsula: Alaska Department of Natural Resources, Division of Oil \& Gas, Alaska Peninsula Resource Series, plate 4 of 4, http://www.dog.dnr.state.ak.us/oil/.

Mickey, M.B., Haga, H. Boettcher, R.S., and Kling, S.A., 2005, Northwestern Alaska Peninsula—Bristol Bay basin biostratigraphy study, Micropaleo Consultants Job No. 25-104, 287 p., 4 oversize plates, 40 oversize figures, Alaska Division of Oil \& Gas online publication http://www.dog.dnr.state.ak.us/oil/products/publications/ akpeninsula/biostrat.htm

Miller, D.J., Payne, T.G., and Gryc, George, 1959, Geology of possible petroleum provinces in Alaska: U.S. Geological Survey Bulletin 1094, 131 p., 6 plates.

Molenaar, C.M., 1980, Cretaceous stratigraphy, Chignik area, Alaska Peninsula [abs.], American Association of Petroleum Geologists Bulletin, v. 64, no. 5, p. 752.

Reifenstuhl, R.R., and Finzel, E.S., 2005, Bristol Bay, frontier basin, Alaska Peninsula: hydrocarbon resources, petroleum reservoir characterization, and source potential: Geological Society of America Abstracts with Programs, v. 37, no. 4, p. 96.

Reifenstuhl, R.R., Bailey, Rebecca D., and Finzel, E.S., 2005, Bristol Bay and Alaska Peninsula 2004: Fieldwork and Sample Analyses Compilation Report: Alaska Division of Geological \& Geophysical Surveys Preliminary Interpretive Report 2005-1, 22 p.

Schweitzer, C.E., and Feldmann, R.M., 2000, Re-evaluation of the Cancridae Latreille, 1802 (Decapoda: Brachyura) including three new genera and three new species: Contributions to Zoology, v. 69, no. 4, p. 233-250.

Schoell, Martin, 1983, Genetic characterization of natural gases: American Association of Petroleum Geologists Bulletin, v. 67, no. 12, p. 2225-2238.

Turner, R.F., (ed.), 1988, Geological and operational summary, North Aleutian Shelf COST No. 1 well, Bering Sea, Alaska: Minerals Management Service Alaska OCS Report MMS 88-0089, 256 p., 2 plates.

Waldron, H.H., 1961, Geologic reconnaissance of Frosty Peak volcano and vicinity, Alaska: U.S. Geological Survey Bulletin 1028-T, p. 677-708.

Walker, K.T., McGeary, S.E., and Klemperer, S.L., 2003, Tectonic evolution of the Bristol Bay basin, southeast Bering Sea: Constraints from seismic reflection and potential field data: Tectonics, v.22, no. 5, p. 1-19.

Waring, G.A., 1965, Thermal springs of the United States and other countries of the world-a summary: U.S. Geological Survey Professional Paper 492, 383 p. 
White, J.M., in prep, Palynological report on 20 samples of Neogene age from the Bear Lake Formation, Alaska Peninsula (in preparation).

Wilson, F.H., Detterman, R.L., and Case, J.E., 1985, The Alaska Peninsula terrane: A definition: U.S. Geological Survey Open-File Report 85-450, 19 p.

Wilson, F.H., Detterman, R.L., and DuBois, G.D., 1999, Digital data for geologic framework of the Alaska Peninsula, Southwest Alaska, and the Alaska Peninsular Terrane: U.S. Geological Survey Open-file Report 99-317, 41 p., 1 sheet, scale 1:500,000.

Worrall, D.M., 1991, Tectonic history of the Bering Sea and the evolution of Tertiary strike-slip basins of the Bering Shelf: Geological Society of America Special Paper 257, 120 p., 1 oversize sheet, 4 plates. 